IZA DP No. 5291

Teacher Pay, Class Size and Local Governments: Evidence from the Latvian Reform

Mihails Hazans

October 2010 


\title{
Teacher Pay, Class Size and Local Governments: Evidence from the Latvian Reform
}

\author{
Mihails Hazans \\ University of Latvia \\ and IZA
}

Discussion Paper No. 5291

October 2010

\author{
IZA \\ P.O. Box 7240 \\ 53072 Bonn \\ Germany \\ Phone: +49-228-3894-0 \\ Fax: +49-228-3894-180 \\ E-mail: iza@iza.org
}

\begin{abstract}
Any opinions expressed here are those of the author(s) and not those of IZA. Research published in this series may include views on policy, but the institute itself takes no institutional policy positions.

The Institute for the Study of Labor (IZA) in Bonn is a local and virtual international research center and a place of communication between science, politics and business. IZA is an independent nonprofit organization supported by Deutsche Post Foundation. The center is associated with the University of Bonn and offers a stimulating research environment through its international network, workshops and conferences, data service, project support, research visits and doctoral program. IZA engages in (i) original and internationally competitive research in all fields of labor economics, (ii) development of policy concepts, and (iii) dissemination of research results and concepts to the interested public.
\end{abstract}

IZA Discussion Papers often represent preliminary work and are circulated to encourage discussion. Citation of such a paper should account for its provisional character. A revised version may be available directly from the author. 


\section{ABSTRACT}

\section{Teacher Pay, Class Size and Local Governments: Evidence from the Latvian Reform*}

This paper employs a rich collection of survey and administrative datasets, including linked school-teacher payroll data, to document the reform of teacher compensation and school network implemented in Latvia amidst the economic crisis of 2008-2010, immediately after territorial reform. We explore diverse responses by local governments in terms of proportion of state subsidy transferred to schools, extent of redistribution of state funds between schools, degree of autonomy in compensation policies given to schools, and municipal contribution to school wage bills. Other things equal, municipalities tend to redistribute funds from schools with high student-teacher ratio $(\mathrm{S} / \mathrm{T})$ to ones with low $\mathrm{S} / \mathrm{T}$. Nevertheless, the reform has changed the effect of the local student-teacher ratio on teacher earnings per workload from negative to positive of the same size. Survived schools feature strong heterogeneity in terms of workload and staff reduction, change in class size, and compensation strategies. We provide evidence for a substantial incidence of using performance-related criteria for teacher base salary differentiation. We analyze school and individual level determinants of teacher pay using mixed models with municipality and school level random effects.

JEL Classification: $\quad \mathrm{H} 75, \mathrm{I} 22, \mathrm{I} 28, \mathrm{~J} 31, \mathrm{~J} 33, \mathrm{~J} 45, \mathrm{M} 52, \mathrm{C} 23$

Keywords: teacher compensation, local governments, linked employee-employer data

Corresponding author:

Mihails Hazans

Faculty of Economics and Management

University of Latvia

Aspazijas Blvd 5

Riga LV-1050

Latvia

E-mail: mihazan@lanet.Iv

\footnotetext{
Financial support from the World Bank as part of its assistance to the Government of Latvia to develop an Emergency Social Safety Net Strategy (2009) and Republic of Latvia Public Expenditure Review (2010) is gratefully acknowledged. I thank directors of 577 schools and representatives of 85 local education authorities who took part in the online surveys conducted in March 2010. I thank Truman Packard, Michael Mertaugh, Charles Griffin, Ihsan Aiwad and Lars Sondergaard for helpful discussions, support and encouragement. I thank Aija Rudmane, Astra Cīrule, Dmitrijs Kuḷı̌s, Inga Štāle, Lidija Rapoporte, Initra Pavloviča, Maksims Kazakovs and Kristīne Vagnere of Latvian Ministry of Education and Science, as well as Minister Prof. Tatjana Kokse, for data, background information and fruitful discussions. I thank Dmitrijs Kulı̧šs and Renārs Felcis for logistical and technical assistance with the online surveys. Labor Force Survey data used in this paper were provided by Statistics Latvia. The paper benefited from comments on the previous versions by the participants of public presentation (June 2009) and the meeting of the multilateral working group "Money follows student" (June 2010). I thank Anthony Clarke from UK Department of Education for clarification on OECD methodology for calculating student/teacher ratio. Remaining mistakes are my own. Views expressed in this paper are not necessarily endorsed by the World Bank or Latvian Ministry of Education and Science.
} 


\section{Introduction}

This paper employs a rich collection of survey and administrative datasets, including full coverage linked school-teacher-task payroll data, to document the reform of teacher compensation and optimization of school network, which occurred in Latvia amidst the economic crisis of 2008-2010, immediately after territorial reform and municipal elections. Moreover, the teacher wage bills were cut by half in September 2009 and then increased by one third in January 2010, thus allowing for analysis of decision-making patterns in these opposite situations.

The context of these developments is two-fold. On one hand, in comparison to most of the developed countries, Latvian teachers are substantially underpaid relatively to the country's income level: since 2006, nominal statutory teacher salary was fluctuating between 54\% and 63\% of GDP per capita, the average for school year 2009/2010 being 60\%, while the OECD average (as well as the average for the 19 EU/OECD members) is more than twice as high (Figure 1); just 5 out of 33 comparison countries pay their teachers significantly less than $100 \%$ of GDP per capita ${ }^{1}$. Furthermore, both before the crisis and after the increase in funding in early 2010, teacher average earnings per workload stayed at about two thirds of public sector average full-time equivalent earnings (Figure 3); in terms of total monthly earnings, teachers' relative position within the public sector improved compared to the pre-crisis period, yet their average earnings lag behind those of employees in state budget institutions (Figure 3; more details found in Hazans, 2010). This is despite nearly 100\% of teachers have higher education, which is not the case for the comparison group.

On the other hand, during the decade prior to the crisis, the number of students in schools of general education has declined by one third due to negative demographic trend, while the number of teachers has declined by just 5\%. Before the reform, Latvian net student-teacher ratio was less than two thirds of the average OECD or EU-19 level (Figure 4). Classes were not unusually small on average, yet $10 \%$ of primary students were in classes of size 10 or less, a unique situation among EU countries (Figure 5). Note that at the lower secondary level, classes in Latvia are even smaller than at the primary level. Thus, the crisis triggered a reform which was ‘in the pipe-line’ anyway.

This paper pursues several objectives. First, we aim at exploring the diversity of strategies and outcomes both at the municipal and at the school level. This is of considerable interest because fiscal tightening came with a substantially increased flexibility in decision making, especially for the school heads. Many of the directors have used this flexibility in compensation policy to make the base salary performance-related. More generally, survived schools feature strong heterogeneity in terms of workload staff reduction, change in class size, the share of municipal funding in teachers' compensation, average level of and within-school variation in statutory salary per teaching workload,

\footnotetext{
${ }^{1}$ Given that Latvian teachers carry, on average, more than one workload, we also compare total annual average earnings of classroom teachers of public schools in Latvia, US, four Western European and Nordic countries, seven of the Central and Eastern European EU members, as well as Russia and Belarus (see Figure 2). Annualized average gross earnings (in the given school) of Latvian classroom teachers carrying at least one full workload in 2009/2010 were equivalent to about 90\% of the 2009 GDP per capita, well above similar indicators for Estonia, Slovakia, Russia and Belarus, close to Czech R., Lithuania, and Norway, but very much below Hungary, US, Finland, Romania and Poland, let aside UK and Germany.
} 
as well as compensation strategies. We focus mainly on wages, while a more comprehensive analysis of determinants of closing and job cuts is left for a separate paper.

Second, we try to identify strategies and policies that are pro-efficient or counter-efficient from the cost perspective, as well as those which provide (or destruct) incentives for better teaching quality. The reform triggered a substantial improvement in cost efficiency (measured by student/teacher ratio or class size). Econometric analysis reveals that the effect of municipality level student/teacher ratio on teacher earnings per workload, which, due to input-based financing combined with some counterefficient regulations, was negative before the reform, after switching to per-student financing has changed its sign (whilst keeping the same size and significance). However, the full effect of schoollevel cost efficiency on teacher earnings is not yet revealed because local governments redistribute funds between schools.

Third, we analyze determinants of teacher pay at the levels of municipality, school, and individual, using mixed panel data models which combine time invariant teacher and school characteristics with random municipality-specific and school-specific effects.

Our paper contributes to several strands of the literature: studies on regional variation and compensating differentials in teachers' salaries (see Kenny and Denslow (1980), Walden and Newmark (1995), Walden and Sogutlu (2001), Stoddard (2005), Tuck, Berman and Hill (2009) among others); school autonomy and performance-related pay for teachers (Southwick and Gill (1997); Ballou (2001); Wößmann and Schütz 2006 and references therein); equity, efficiency, and role of local governments in resource allocation to schools (Baicker and Gordon (2006); Frey and Eichenberger (2006); Sutherland et al. (2007); Gordon and Knight (2008); BenDavid-Hadar and Ziderman (2010); Billger (2010); Bu, Wang and Hou (2010); Reiljan and Friedrich (2010) among others).

The rest of the paper is organized as follows. Section 1 compares regulation of teacher compensation in Latvia before and after the reform. Section 2, based on full-coverage panel data from annual school surveys, analyzes school closures and mergers, job cuts and workloads reductions, as well as changes in class size and school size. Section 3 employs very representative surveys of local education authorities and school directors to explore their post-reform compensation strategies. Furthermore, it applies full-coverage school level payroll data to examine variation in base salaries and teacher earnings within and across schools, as well as to provide econometric analysis of the school level determinants of the share of municipal funding in teacher compensation, as well as the patterns of redistribution performed by local governments. Econometric analysis of local, school, and individual level determinants of teacher pay (based on the above mentioned linked teacher-school-task payroll data) provides is found in Section 4. Section 5 concludes and provides policy recommendations. 


\section{Regulation of teacher salaries in Latvia}

Gross monthly pay for teaching $E_{t}$ in Latvia's schools is determined by three factors:

statutory teacher's salary $W_{t}$ (the wage rate for one full workload equivalent to 21 [academic] hours per week);

(ii) number of teaching contact hours per week, $H_{\text {cont }}$;

(iii) number of paid hours allocated for complementary instructional tasks: preparation for the lessons $\left(H_{\text {prep }}\right)$, individual consultations $\left(H_{\text {ind }}\right)$, correction of written assignments $\left(H_{\text {corr }}\right)$, and class supervision $\left(H_{\text {supv }}\right)$;

(iv) pay supplements S (for quality, for work with special needs students, for increased amount of work, etc.; see Table 1 for details):

$$
E_{t}=W_{t} L_{t}+S, L_{t}=H / 21, H=H_{\text {cont }}+H_{\text {prep }}+H_{\text {ind }}+H_{\text {corr }}+H_{\text {supv }}
$$

Here $L_{t}$ stands for the number of teaching workloads. Some teachers, in addition to teaching, perform administrative or other support duties (school directors and deputy directors, speech therapists, school librarians, school psychologists, etc.), so total gross monthly earnings are given by

$$
E=E_{t}+\sum_{k} W_{n t, k} L_{n t, k},
$$

where $W_{n t, k}$ is the wage rate for non-teaching job $k$, and $L_{n t, k}$ is the number of full-time workloads carried by the teacher in question in this job (for a staff member who does not teach, $E_{t}=0$ in (2)).

Table 1, based on Cabinet regulations 746, 545, 836 and 1616 (Republic of Latvia Cabinet of Ministers 2004-2009) describes the main features of the teachers' remuneration system (details for non-teaching jobs omitted) before and after the reform enforced as of September 2009. Before the reform, given the approved study programs implemented by the school, its wage bill was determined mainly by the number of classes at each grade level. The number of students had its (less than proportional) impact mainly through the number of classes ${ }^{2}$. The number of students affected the wage bill also because wage rates of director and deputy directors (see Table 1), as well as and the number of deputy directors and support staff members in the school (we omit the details) were larger in larger schools; this impact, however, was weaker that through the number of classes.

So, the schools were interested in attracting students, but also (and perhaps even more so) in having smaller classes. The incentive to have smaller classes was reinforced by using discrete class size bands rather than number of students when allocating hours for class supervision and especially for correcting the assignments (see Table 1 for details), as such regulation favored teachers working

\footnotetext{
${ }^{2}$ In standard programs, classes up to 30 students were allowed; the lower limit varied, depending on type of settlement, from 8 to 15 in grades 1 - 9 and from 12 to 22 in grades 10 - 12 . $K$ (up to 6 ) parallel classes were allowed if the number of students at the given grade level exceeded $30(K-1)$ and the lower limits mentioned above were respected (note there was some degree of discretion at the local authority level).
} 
near the lower limit of each band (e.g. 16 rather than 25 or 26 rather than 30 students). This created some unfairness in pay without any good reason; indirectly, this also favored schools with lower student - teacher ratio (and, therefore, schools located in small cities or rural areas as opposed to those located in big cities). Below we provide empirical evidence that this was indeed the case.

After the reform, school's state funded monthly wage bill ( $\left.W B_{\text {state }}\right)$ is proportional to the normalized number of students, NS (this does not apply to schools for special needs children, as well boarding schools, which are funded by a separate scheme not discussed here). Assuming for a moment away evening or correspondence schools and programs, as well as special and in-depth programs in regular schools,

$$
N S=(0.75 \text { prestud }+0.75 \text { stud(1-4) }+ \text { stud(5-9)+1.25stud(10-12)) }(1+0.1 G)
$$

where prestud is the number of 5-6 years old children in mandatory preschool education ${ }^{3}$, stud( $(a-b)$ is the number of students in grades $a$ to $b$, and $G=1$ for state gymnasiums ${ }^{4}$ (otherwise $G=0$ ). Evening (part-time) and correspondence students of all grades are included with coefficient 0.82 . Students of programs with in-depth study of some specific subject are included with coefficient 1.31. Finally, students in special classes of usual schools, as well as special needs students integrated in usual classes, are included with coefficient 1.47 .

The normalized number of students is divided by an 'imposed' student-teacher ratio $R(R=10.2$ for republican cities, while elsewhere $R=8$ ) to get the notional number of state-funded workloads, which is then multiplied by an amount $A$ determined (once or twice each year) by the Cabinet: $W B_{\text {state }}$ $=A \times N S / R$. Of this amount, $10 \%$ are allocated for compensation to administrative and support staff. Importantly, all restrictions on class size ${ }^{5}$ and on the number of administrative and support staff members have been lifted as of July 2009, allowing school directors (or local governments, if they intervene, as for instance in Riga, where almost all support staff is funded by the city) to use available funds as they find fit.

In practice, local governments facing tough budget cuts have decided to close some schools and to merge ('reorganize') some others, meaning that just one of the group of several reorganized schools continues as an organization, under either the old or a new name, and absorbs, supposedly, most teachers and students of other group members; in some but not all cases all schools being reorganized as a group moved into one building. After that, the directors of surviving schools had to decide on firing or keeping their teachers, hiring new teachers (in case of reorganized schools), allocation of workloads, and setting the wage rates $W_{t}$ and $W_{n t}$ for individual teachers (in some municipalities, directors' freedom in wage setting has been restricted by the local governments, we come back to this below).

\footnotetext{
${ }^{3}$ In September - December 2009, preschool students were not counted in the formula but financed separately. Note that not all schools provide pre-school education.

${ }^{4}$ Just 22 out of more than 800 general education schools have the status of state gymnasia.

${ }^{5}$ Except by restrictions implied by health-related regulations.
} 
In terms of incentives, the new system motivates schools to have more students (especially at the upper secondary level). As far as class size is concerned, given limited (and sharply reduced) funds, the director is motivated to have larger classes (implying fewer teachers and/or lower earnings per teacher). On the other hand, 'money follows student' financing forces the directors to keep in mind students' and parents' satisfaction and school reputation, hence teaching quality and teachers' satisfaction; this creates an incentive not to make classes too large.

The size of school gross monthly wage bill per one normative student is given by

$$
\left(W B_{\text {state }}\right) / N S=a \text { in republican cities, }\left(W B_{\text {state }}\right) / N S=b \text { elsewhere, } b=1.275 a \text {, }
$$

where $a=(A / 10.2) /(1+s), A$ is the state funding for one notional workload, $s=24.09 \%$ is the employer's social contribution rate, and $1.275=10.2 / 8$ is the ratio of 'imposed' student-teacher ratios. For September - December 2009, $a=L V L 28.95$ and $b=L V L$ 36.91, while for January -August 2010, after a $33 \%$ increase, $a=L V L 38.60$ and $b=L V L 49.21^{6}$ (note that $1 \mathrm{LVL}=1.42 \mathrm{EUR}$ ).

Due to budget cuts triggered by the economic crisis, the amount of money allocated for teacher compensation per one student in September 2009 was roughly half of its value a year ago, both on average in the main cities and on average in the 26 districts (rajons). After an increase in January 2010, the state funded teacher wage bill per one student has reached, on average, LVL 38.66 in the seven main cities, LVL 47.64 elsewhere, and LVL 43.38 in the whole country, i.e. about $65.5 \%$ of the pre-crisis level.

Composition of the student pool differs across municipalities; therefore state funding per real (rather than normative) student differs as well. However, under the 'money follows student' these regional disparities are much smaller than under the old, input-based system (Figure 6). In September 2008, the maximal allocation among the seven republican cities was by one third higher than the lowest, while after the reform the similar gap was just $6 \%$, and coefficient of variation felt from 0.102 to 0.023 . Likewise, among the 26 districts the max/min ratio dropped from 1.6 to 1.2 , and the coefficient of variation decreased from 0.106 to 0.041 . During the territorial reform also implemented in summer 2009, two cities, Jekabpils and Valmiera, have been granted the 'republican' status. As the result, the imposed student/teacher ratio is 10.2 for these two cities, and the average per-student allocation is substantially smaller in (former) Jekabpils and Valmiera districts than in other 24 districts (Figure 6).

\footnotetext{
${ }^{6}$ Recall that this refers to 'usual' public schools of general education, i.e. board schools, special schools, private schools and professional schools are excluded. Also excluded are interest group teachers funded from a special state grant for interest education; this grant is distributed by local education authorities, not necessarily on perstudent basis.
} 


\section{Optimization of the school network}

Within the constraints imposed by amount of per-student financing, both local governments and school administration have considerable flexibility in influencing average level and dispersion of teacher earnings. First, by closing and/or merging least efficient schools, local governments could increase average teacher pay level; school principals could do so by merging classes and optimizing teacher deployment. Table 2 demonstrates that between September 2008 and September 2009 (mainly, during the summer 2009), the number of general education schools declined by about $11 \%$, as did the number of classroom teachers (teaching staff), while the number of class sets decreased by about $8 \%$. Within each type of settlement, closed (or absorbed via merger) schools were much smaller than others (Figure 8); moreover, they featured lower student/teacher ratio, higher per-student maintenance cost, and more pronounced decline in the number of students over the last 6 years (Hazans 2010). Thus, the choice of schools for closures and mergers made by new local governments seems, by and large, reasonable. ${ }^{7}$ A more comprehensive analysis of determinants of closing decisions is left for a separate paper.

Teaching staff declined by $12 \%$ in terms of posts ${ }^{8}$, while total school staff declined by $15.5 \%$; reductions in terms of persons employed were smaller by one point. The number of teaching and total workloads has been cut by $25 \%$ and $29 \%$. This resulted in efficiency gains: the number of students per teaching staff post (known as the gross student/teacher ratio) and the number of students per teaching workload (the net student/teacher ratio) increased, respectively, from 9.3 to 10.2 (by 9.4\%) and from 7.4 to 9.5 (by 27.9\%), thus reversing previous trend towards inefficiency (see Table 2 for details). Average class size has increased from 18.5 to 19.3 (by 4.3\%). Figure 7 illustrates. Efficiency gains are even larger when special, board and private schools are excluded (Table 2, panel B). Even after corrections made possible due to January increase in financing, increase in gross (respectively, net) student/teacher ratio vs. the pre-reform level was 7\% (respectively, 13\%).

Now we turn to a more detailed analysis of the key elements of the reform.

\subsection{Workload reductions and job cuts}

Figure 5 displays, for the whole country and by urbanization level, as well as by school size, distribution of schools by percentage changes in the number of compensated workloads and in the school staff. Hereafter in this subsection, only public schools are considered. Boarding and special schools, which are financed through a different scheme, are excluded. Reorganized (merged) schools do not have natural pre-reform comparators and are excluded as well.

\footnotetext{
${ }^{7}$ Note that this is not always the case in international practice: Billger (2010) reports that in Illinois, schools with higher per-student spending were less likely to close, other things equal, and that composition of students in terms of race and socioeconomic status played its role, too.

${ }^{8}$ Each staff member counts once in every school he/she works at.
} 
On the whole, half of the schools experienced reduction of 20 to $40 \%$ of workloads, with median at about $30 \%$. The other half splits into two equal groups. School from the bottom quartile lost 40 to $65 \%$ of workloads $^{9}$, while schools from the top quartile lost less than $20 \%$ of workloads or even gained up to $5 \%$. Thus, there was a very strong heterogeneity across schools in terms of workload reduction; this heterogeneity is observed also within each of the four types of settlement. Schools which were overstaffed more than others (within the same type of settlement) lost relatively more workloads. Another source of heterogeneity is of course related to the fact that outside the nine republican cities state funding per normative student is by $27.5 \%$ larger than in these cities.

The largest reductions are found for rural schools (with median at 35\%), while schools in small cities experienced the smallest workload cuts (with median at 20\%). Rural schools were typically much smaller than urban ones (Figure 8) and had substantially less students per teacher, hence switching to a per-student financing was especially painful for them. On the other hand, population density in small cities is high enough to support student/teacher ratio not much below than is found in the large cities, while enjoying the preferential treatment in the financing formula. The capital city, Riga, is between these two extremes, with median reduction of $27 \%$. Other republican cities with median of 33\% are closer to rural areas, although observed changes vary in a more narrow range (from $-55 \%$ to $-9 \%$, excluding some outliers) than for rural schools (from $-70 \%$ to 0 ). Thus, by closing more schools than other republican cities, Riga has mitigated the reform effect on surviving schools.

The pattern of the change in instructional (teaching related) workloads is similar to that for total workloads, although median reduction is by 4 points smaller. Staff reductions have been much more modest than workload cuts: more than a half of schools have cut up to $20 \%$ of teachers and other school staff, a quarter of schools - 20 to $40 \%$. Moreover, one out of ten schools has shown an increase in total school staff, and one out of four schools - an increase in the number of classroom teachers. In other words, like in other sectors, the impact of the reform has been split between layoffs and reduction of workload per employee.

\subsection{Classes and schools getting larger...if there is enough pressure}

As of September, 2009, average class size in public schools of general education in Latvia is 19 for primary education, 18.6 in lower secondary (grades 5 to 9) education, and 23.1 in upper secondary education. International comparisons using data from OECD (2009) and EACEA P9 Eurydice (2009) show that at the primary level, Latvian average class size is well above that in Russia, Greece, and Slovenia, and very close to those found in Iceland, Italy, Estonia, Spain, Portugal, Switzerland, Slovakia, Czech R., Hungary, Poland, Austria, Belgium, Finland, Denmark, as well as EU-19 average. For lower secondary education, Latvian class size is above that of Russia and just slightly below those found in Switzerland, Slovenia, Belgium, Iceland, Finland, Denmark, Ireland, but lags behind average

\footnotetext{
${ }^{9}$ Schools with abnormally large positive or negative changes excluded.
} 
of EU-19 by 3.6 units. Within each level and type of settlement, class size varies significantly across schools, suggesting that there might be a room for increasing average class size ${ }^{10}$ (Figure 10).

The reform effect on class sizes strongly varies by type of settlement. We illustrate this point using data on grades 1-4. Figure 11 presents, separately for republican cities, other cities and rural areas, percentiles p10, p25, p50, p75, and p90 of the distribution of primary students in Latvia by class size in September 2009, along with the changes in these percentiles since September 2008. The figure reveals a striking difference between schools in small cities and other schools. In rural areas and in republican cities, class size increased very substantially, especially (by 8 to 14\%) as far as smaller classes are concerned, but also at the median of the distribution (by 7\% in republican cities and by $12 \%$ in rural schools). By contrast, in small cities, small and medium classes have not increased at all, whilst increase at the 10th percentile (i.e. with respect to the smallest classes) was just half of that in big cities. This is despite the fact that in small cities small and big classes alike are by 4 to 5 students smaller in than in the republican cities. Why did not schools in small cities increase their class sizes? The explanation should be sought in the financing formula (4): before the reform, schools in small cities, unlike rural schools, were in general of size comparable to that of schools in republican cities (see Figure 8), yet under the money follows student scheme they (like rural schools) received by $27.5 \%$ more funds per student. Thus, schools in small cities were not under so strong pressure to consolidate as were schools in big cities.

Figure 12 confirms it by looking at the changes in the school size across the size distribution. The structure of the figure is similar to that of Figure 11 but the percentiles refer to schools rather than students (this is because schools are the potential objects of consolidation aimed at increasing school size). The median school size has not changed in small cities but increased by $6 \%$ in republican cities and by $10 \%$ in rural areas. The size of 'very small schools' (those at the $10^{\text {th }}$ percentile of the size distribution) has increased by $37 \%$ in republican cities and by $24 \%$ in rural areas, but by just $15 \%$ in small cities.

\section{Teacher salaries: School heads' and local governments' strategies}

As discussed in section 1, earnings of a teacher with a specific workload in a given school depend on her statutory salary for one workload (hereafter, we will call it wage per load or base salary), as well as on the number of hours allocated for performing complementary instructional tasks. After the reform, local governments (indirectly) and school heads (directly) have, in principle, substantial flexibility in setting base salaries for individual teachers, as well as in setting rules for allocating hours within available wage bill. Such a flexibility, especially on the school heads' side, is an important complement to the 'money follows student' principle. For school heads to be able to maintain and

\footnotetext{
${ }^{10}$ In this paper, we do not discuss the issue of what is the 'right' class size. There is evidence that smaller classes may improve outcomes in early grades and for specific groups (e.g. lower-income, disadvantaged students or the best-performing students) or in specific circumstances (e.g. when the teaching quality is low): see Rivkin, Hanushek \& Kain (2005); Wößmann \& West (2006); OECD (2009: p. 372); EACEA P9 Eurydice (2009: p. 221.
} 
improve quality of teaching, they should have an instrument for motivating teachers. Furthermore, local governments can contribute to teacher compensation from their own budgets; they can also provide teachers with some employee benefits (e.g. health insurance). This section examines strategies chosen by local governments and school heads regarding teacher pay.

In order to understand to what extent and how do local governments influence teacher compensation, a survey of local education authorities has been conducted in March 2010. Out of 118 municipalities, 85 responses were obtained. The response rate was 70 to $83 \%$ among urban and mixed urban-rural municipalities and 58\% among the rural ones. In republican cities and mixed urban-rural counties, responding municipalities cover $90 \%$ of municipal schools, whilst in other counties the coverage is about two thirds; furthermore, in three out of five regions, the coverage rate is between 89 and $97 \%$, and in two other regions - between 70 and $80 \%$. One can conclude that the survey was sufficiently representative (see details in Hazans, 2010: Tables 12, 13).

At the same time, an online survey of school principals was conducted ${ }^{11}$. The main focus of this survey was on differentiation of teacher pay within schools (or the reasons of lack of differentiation). This survey was also quite representative: 577 of 838 municipal schools, or almost $70 \%$, have responded; response rate varies between 58 and $67 \%$ by type of municipality and between 59 and $77 \%$ by region (Hazans, 2010: Table 13).

\subsection{Do local governments tell school heads how should they pay their teachers?}

The results of the survey of local education authorities are presented in Figures 13-14. Immediately after the reform, when teacher wage bill suddenly dropped by about $50 \%$, almost half of municipalities came out with rules prescribing how schools should set basic salaries; $15 \%$ issued nonmandatory recommendations, and in 37\% cases schools could decide independently (Figure 13). Since January 2010, when budgets became less tight, the latter category increased to $54 \%$, whilst only $28 \%$ of local government continued to regulate wage setting in schools. As far as allocation of compensated hours for class supervision and homework correction is concerned, about two thirds of local governments do not intervene at all, and the rest are split almost equally between non-mandatory recommendations and mandatory rules (Figure 13).

How much real influence do local authorities have on teacher wage setting? Table 4 sheds light on this issue using evidence from both municipalities' and directors' surveys, as well as from school payroll data (to be discussed in more detail in this and two subsequent sections). Both directors' survey and school payroll data indicate that about $60 \%$ of municipal schools do not vary classroom teachers' (excluding school heads and deputy heads) base salaries. In directors' survey, slightly less than half of such schools (26\% of all respondents) refer to local government instructions or recommendations as the main reason to avoid wage rate differentiation. On the other hand, according

\footnotetext{
${ }^{11}$ At the moment of this survey, detailed schools' payroll data were not yet available. When the same information is available from the survey and payroll data, we use the latter.
} 
to the survey of local education authorities, more than a half of them do not provide any guidance to schools with regard to base salary differentiation, while only $18 \%$ provide rules or recommendations which include some criteria for base salary differentiation, and $28 \%$ either discourage such differentiation or do not include any criteria in their recommendations (Table 3; Figure 14).

Finally, it makes sense to check if most schools within given municipality follow similar strategies. Among 109 counties with more than one municipal school, there are $61 \%$ where at least $3 / 4$ of schools either do not differentiate classroom teachers' base salary at all or keep it within a 10 LVL range $^{12}$. Note that among these schools only in 55\% the base salaries are kept at the minimal level allowed by the law (see Table 1), while in the rest maximal wage per load varies (across schools) from 260 to 360 LVL. Thus, while the level of pay is not the same in these schools, they apply the same "equal wage rate" (or solidarity) strategy.

It is worth noticing that about $70 \%$ of schools applying this strategy are rural (in municipalities where this strategy prevails this proportion raises to 77\%). Thus, social norms, plausibly, have played some role in the choice if this strategy in cases when the wage rates are above the legal minimum.

The number of municipalities where equal wage rate is the dominating strategy is significantly larger than the number of those which formally issued strict rules or even recommendations in this regard; one might thus assume either an informal influence of the local government or (more plausibly) informal coordination between schools. On the other hand, the strategy of differentiating wage per workload, used by about $40 \%$ of the schools, clearly prevails just in $7 \%$ of the municipalities. So, this strategy was to a much more extent a matter of choice by the management of individual schools.

When local governments do encourage wage rate differentiation (which happens just in one out of six cases, see Figure 14), what criteria do they suggest to use? One out of eight municipalities (we use all 118 municipalities as a base) mention teachers who provide officially acknowledged methodological support to colleagues. Teacher's extra activities in the school and belonging to school management (each with $8 \%$ of all municipalities) share the $2^{\text {nd }}$ spot, followed by subjects taught and students' special achievements (less than $5 \%$ each), as well as quality of work and innovation (less than $3 \%$ each). Just $1 \%$ mentions exam results in previous years or a distinction between upper secondary and basic school (Figure 14). Note that the experience criteria were not asked about in the municipalities' survey, as it is explicitly mentioned in the Cabinet regulations.

\subsection{Compensation strategies chosen by schools}

By comparison (see Figure 15), the most popular criteria for differentiating base salary in the schools are: work experience (36\% of all schools), extra activities in the school (15\%), reputation and quality of work (14\%), students' special achievements (12\%) and innovations (11\%). Note that except

\footnotetext{
${ }^{12}$ Base salary variation within a $10 \mathrm{LVL}$ range can be considered as no variation, because the minimum rates mentioned in the Cabinet regulation vary between 245 and 255 LVL depending on teacher experience.
} 
for experience, all these are qualitative criteria, use of which has a motivating effect. Popularity of these criteria (which are not always easy to formalize) is a good sign, and the use of those should be encouraged. Slightly less popular are more formal criteria, such as being a methodologist (10\%), weekly workload (10\%), completed professional development courses (9\%), and students' exam results in the previous years (8\%). At least one of the quality-related criteria (teacher reputation, quality of work and innovation, students' exam results and special achievements) is applied in 15\% of the schools, and the incidence of this practice is sharply increasing with school size, reaching $24 \%$ among schools with 300 to 500 students and 30\% among larger schools (Figure 16). Such criteria as subjects taught, using bilingual education, working in upper secondary $\left(10^{\text {th }}\right.$ to $\left.12^{\text {th }}\right)$ grades, and belonging to school management were mentioned by 1.5 to $3 \%$ of schools.

Schools which apply the equal wage rate strategy or use differentiate wage rate only by teacher experience were asked about reasons. One third of all schools (both applying the equal wage rate strategy and the others) referred to recommendations by the local education authorities; $19 \%$ directors were not sure whether differentiation is allowed; $12 \%$ said they think it is right way to go; 8 to $9 \%$ mentioned desire to avoid conflicts among teachers and lack of time to work out criteria (Figure 17).

The extent to which schools and local governments can create opportunities for individual teachers to increase their earnings through paid overtime work in teaching and other tasks are of course limited by the total wage bill; if the latter is not sufficient for complete financing of the study program, schools face a trade-off between reducing teacher earnings or dropping some elements of the program. Figure 18 indicates that almost $60 \%$ of schools had under-financed study programs in SeptemberDecember 2009. This proportion was $61 \%$ in rural areas and $67 \%$ in republican cities, while in other cities it was just $37 \%$. Russian and other minority schools have, on average, suffered from underfinancing more than Latvian schools (63 vs. 55\%). Relatively lower under-financing rates are found among gymnasiums (39\%) and evening schools (33\%). The January increase in funding allowed addressing the problem of under-financed programs to a large extent, but even after that more than $20 \%$ of schools are under-financed. The patterns with regard to type of settlement, language and type of school are as before. As far as school size is concerned, schools with 90 to 150 students appear to be most vulnerable, with under-financing rate of $68 \%$ immediately after the reform and $33 \%$ in the spring semester of 2010 .

\subsection{Variation of teacher pay within and across schools}

This section examines variation of base salaries and teacher earnings within and across schools. We focus on compensation for classroom teacher work (see section 4 on compensation for other functions). Special, board and private schools are excluded from consideration.

Immediately after the reform (in September, 2009) there was almost no variation in teacher pay either within or across schools (Figures 19, 20). This lack of pay variation in the first post-reform semester was caused mainly by extremely stressed budgets. Outliers in Figure 19 suggest, however, that the 
latent preference for motivating compensation schemes revealed itself in schools with more than 300 students, especially in Riga and (to a smaller extent) in other republican cities. Within-school ratio of highest to lowest wage rate per teaching workload varied in a very narrow range between 1 and 1.07 for most schools in the autumn semester 2009, but in spring 2010, it varies from 1.2 to 1.6 for half of schools in Riga (and from 1.0 to 1.2 for the other half). When schools with 300 to 500 (respectively, more than 500) students across all country are considered, for half of them the above-mentioned ratio varies from 1.04 to 1.40 (respectively, from 1.08 to 1.53), see Figure 19.

After the January increase in funding typical wage per workload varies across schools (even when schools with abnormally large wage rates are excluded) from LVL 250 to 360 in republican cities, from LVL 255 to 420 in other cities, and from LVL 250 to 320 in rural schools (Figure 20). Teacher earnings tend to increase with school size, yet substantial variation is found in each size group (Figure 21).

\subsection{Do local governments contribute to teachers' remuneration?}

Local governments can supplement state-funded wage bill by co-funding or fully funding some staff members of functions. As shown in Figure 22, in the fall semester of 2009 (immediately after the reduction of state funding), the share of municipal funding in total teachers' compensation was 6.5\%; the highest local contribution was found in Riga (14\%) and in rural schools (7\%), while it was just $1.1 \%$ in small cities and $2.5 \%$ in republican cities except Riga. After increase in the state funding in January 2010, the share of municipal funding slightly decreased, but, importantly, its amount has increased by more than $20 \%$ in Riga and stayed almost unchanged for rural schools. In other words, extra financing from the state budget has not crowded out municipal funding in localities where its role was substantial (Figure 22, top panel).

The role of municipal funding is negligible as far as curricula-related teaching is concerned, and it is quite small in funding school administration (with exception of rural schools, where $7 \%$ of directors' and deputy directors' compensation was funded by local budgets in September 2009; in April 2010 this share was 5\%). By contrast, about half of compensation for performing support functions, work with pre-school students educated in schools, and interest education is financed by local governments (Figure 22, middle panel). The municipal share in funding school support staff declined from 49\% in September 2009 to 39\% after increase in state funding in 2010, although in absolute terms municipal funding also increased somewhat.

Elementary schools received $18 \%$ of funds for teachers' salaries from local budgets in September 2009; in April 2010 this proportion was 15\%. For basic schools the share of local funding is about two times smaller, while it is about $5 \%$ for secondary schools and below $4 \%$ for evening schools (Figure 22, bottom panel). In absolute terms, however, secondary schools attract the largest part of local expenditures, while expenditures on elementary schools are small. 
Hazans (2010) documents substantial variation of the share of municipal funding across municipalities within each type of settlement. In each type, one in four municipalities does not or almost does not contribute to teachers' compensation, and the median contribution does not exceed $5 \%$. With few exceptions, even the top $25 \%$ of urban and urban-rural counties contribute less than $10 \%$ of total funding, while the top $25 \%$ of rural counties contribute more than $10 \%$ each.

Econometric analysis (see Table 4 for details) reveals that at the school level, apart from county fixed effects, school size, as well as presence and relative size of preschool within school, are the main determinants of the share of municipal funding in teacher payroll. In Riga, in addition, Russian schools receive relatively less municipal funding for teachers' compensation than otherwise similar Latvian schools: the difference is 2.5 percentage points, which corresponds, on average, to 1.8 full workloads. When measured in percentage points, this gap in favor of Latvian schools is larger for small schools, although in terms of workloads it is largest for medium-size schools. This gap is mainly related to funding interest teachers (large dancing and singing collectives are more often found in Latvian schools); when this is excluded, the unexplained gap is reduced to 0.6 percentage points, and when only schools without pre-schools are considered, there is no unexplained gap at all (note that in our sample of non-special and non-board public schools 100 out of 114 schools located in Riga do not operate pre-schools).

\subsection{Do (and should) local governments redistribute state subsidies across schools?}

In principle, local governments are not obliged to allocate funds to schools in exact proportions with the normalized number of students as defined by the MoES. Each municipality can work out specific rules on distribution of the subsidy between schools.

Assuming that the design of the per-student financing is equitable i.e. does not imply unjustified differences in compensation between different schools within municipality, deviations from the builtin scheme should be, in our opinion, allowed only as exceptions. In fact, the main advantage of the per-student financing is the incentives it provides to both local governments and school directors to make schools more cost efficient and to improve quality of education and customer (students and parents) satisfaction. The money should indeed go first to the local governments, to give them possibility to decide on school closures and consolidations when necessary. By the law, such decisions should be made no later than 6 month before the start of school year. After this date, the money should follow to schools proportionally to the normalized number of students. The possibility that local governments can redistribute funds across existing schools undermines the very idea of per-student financing and has a potential to kill directors' motivation to improve their schools beyond the level which guarantees survival ${ }^{13}$. Moreover, in cases of urban-rural counties, such a possibility might undermine motivation of the local governments to close inefficient schools if they can keep them alive by taking some money from larger urban schools.

\footnotetext{
${ }^{13}$ In informal interviews, directors of large schools admit that they don't want to act as donors.
} 
However, if the design of the financing scheme is flawed, municipalities should have a possibility to step in and correct (for instance, by modifying some coefficients). Thus, given that system which has been introduced in school year 2009/2010 has been worked out in a limited time in a crisis environment, it was wise to allow for such a possibility. Once the results of the first year are analyzed and lessons learnt, any revealed imbalances in the system (see Hazans, 2010) should be corrected, and possibilities of redistribution across schools should be limited to a minimum.

In this section we shed light on the extent and patterns of the actual redistribution comparing statefunded remuneration from school payroll data of April, 2010 with the 'normal' wage bill calculated based on the normalized number of students in each school. The latter is derived from the annual school survey data ${ }^{14}$.

We use two versions of the 'normal' wage bill. The first one, referred to as 'the baseline wage bill', does not account for students in so-called 'professionally oriented programs with in-depth study of some subject' ('in-depth programs' hereafter), which should be included with coefficient1.31 (instead of $0.75,1.00$ or 1.25 , depending on study level). The second version ('the extended wage bill') includes the adjustment based on claimed in-depth programs. The reason for separating this issue is that the concept of 'in-depth programs' emerged simultaneously with the reform without a strict definition. According to one MoES official, it was meant for just 10 primary schools where students are taught for instance playing piano or other musical instruments (alongside standard general education program). However, in reality 59 schools claimed about 12 thousands students (5\% of the total enrollment in non-special schools) in such programs; there is both anecdotal and analytical (see below) evidence that in many cases this was used by schools as an instrument to extend the wage bill and by municipalities as a resource for redistribution in favor in small schools. Note that for all but 59 schools the two versions of the 'normal' wage bill coincide.

It should be noticed that in most municipalities, the total (for all schools) amount of compensation according to payroll data falls short of even the baseline wage bill. The difference is, on average, $4.5 \%$, with considerable variation by municipality (see Figure 23). Out of 118 local governments, 37 transfer baseline wage bill in full; in 44 municipalities, the deficit does not exceed 5\%, while it falls between $5 \%$ and $10 \%$ in 20 cases (including Riga with about 6\%). In 8 municipalities (including two of the republican cities) the deficit is between 10 and $15 \%$, whilst 10 counties stand out with $20 \%$ to $30 \%$ of baseline wage bill missing in the April payroll.

Why don't local governments transfer the whole amount? First, when a teacher substitutes a colleague who is on a sick leave or on a mission, the compensation, for some technical reason, is not reflected in the payroll data. More importantly, substitutions related to missions or employercompensated sick leaves imply double payments. Local government officials refer to such cases and other personnel costs which cannot be planned in advance as a reason for keeping part of the subsidy as an 'emergency fund'. According to these officials, it is technically impossible to use this money for

\footnotetext{
${ }^{14}$ Deviations in terms of number and composition of students by school between school survey data and payroll data are negligible.
} 
needs other than teacher compensation, and if not spent, the funds are transferred back to the Treasury by the end of the year. We have not checked the validity of this claim. However, based on past years' data, reasonable size of emergency funds should not exceed 3-4\%. Second, few municipalities are unable to transfer full subsidy because they are in debt to the budget. The debt emerged on the eve of the school financing reform, when some municipalities (including the cities of Daugavpils and Jelgava) paid ‘old size' salaries instead of reduced ones in August 2009. Finally, the municipality can directly act as an employer for some categories of staff (e.g. psychologists or special educators) which work in many schools but do not appear in school payroll files.

Our approach in this section is to calculate the ratio of the payroll data to the baseline wage bill for each school and to perform statistical and econometric analysis of this indicator, as well as of the similar ratio based on the extended wage bill. For municipality level analysis, we use also the third threshold - the actual subsidy transferred to the municipality.

We start at the municipality level, with the objective to find out how systematic differences in the 'undelivered' proportion of the state subsidy are related to characteristics of school systems in each municipality. Results are presented in Table 5. It appears that municipalities with higher student/teacher ratios (gross $\mathrm{S} / \mathrm{T}$ ), which can afford higher teacher salaries, tend to transfer smaller proportion of the state subsidy to schools (after accounting for the composition of the students): an increase in $\mathrm{S} / \mathrm{T}$ by one unit makes the proportion transferred by 1.3 percentage points smaller ${ }^{15}$. This explains the pattern observed in Figure 23: by and large, more urbanized municipalities transfer lower proportions of the subsidy to schools. Nevertheless, the net effect of urbanization is positive: after accounting for differences in student/teacher ratio and student composition, proportion transferred by rural or mixed municipalities are by 5 percentage points lower than for urban ones.

Composition of students in terms of grades does not have a significant effect. Municipalities with larger proportion of distant students tend to transfer less. Plausibly, some municipalities apply to distant students coefficient 0.41 rather than 0.82 (Riga certainly does so), although no distinction between evening and distant students is made in calculation of the state subsidy. We mention the effect of distant students here despite it is not statistically significant (likely due to small proportions of distant students at municipal level), because at the school level it becomes significant.

Municipalities with higher proportions of special needs students integrated in usual schools spend lower proportions of state subsidies on teacher compensation (elasticity is about $-2{ }^{16}$; this might have to do with paying some staff members working with these students in multiple schools directly (rather than through specific schools). By contrast, the share of students claimed as special needs ones beyond the numbers found in the MoES statistics has a positive effect on the proportion of baseline statefunded wage bill transferred to schools (this is an obvious effect because baseline wage bill does not

\footnotetext{
${ }^{15}$ This is consistent with the well-known fact of the income theory that marginal propensity to save increases with permanent income.

${ }^{16}$ When the 10 municipalities, which keep 20 to $30 \%$ of the subsidy, are excluded, this negative effect disappears, but the positive effects of the 'undeclared' special programs and of the in-depth programs remain.
} 
include these claims) and no significant effect on the proportion spent out of the total state subsidy. A similar situation is found with respect to the share of students claimed in 'in-depth programs'.

Finally, for the two urban municipalities with significant debt to budget (Daugavpils and Jelgava) proportion of subsidy transferred to schools is by about 9 percentage points lower than for otherwise similar municipalities without such problems.

Importantly, above mentioned systematic factors explain just about one third of total variation of the dependent variable; the largest part has to be ascribed to heterogeneity of the decision makers.

We proceed with school level analysis. We find clear evidence that municipalities redistribute funds from big schools to small ones (Figure 24, top chart): the median proportion of baseline wage bill is $114 \%$ for schools with less than 90 students, $106 \%$ for schools with 90 to 149 students, $97 \%$ for schools with 150 to 299 students, 95\% for schools with 300 to 499 students, and 90\% for schools with 500 or more students. In mixed urban-rural municipalities, redistribution goes from schools located in towns to rural schools (median proportion of baseline wage bill $91 \%$ and $112 \%$, respectively, see Figure 24, bottom chart, which also shows that the former proportion is lower than in urban municipalities, while that latter is higher than in rural counties). In the same chart we present for comparison data of September, 2009. Although these data refer to the first post-reform month, when irregularities and delays were quite likely, it is evident that redistribution was stronger in September (i.e., under a tighter budget).

Figure 25 suggests that redistribution goes also from secondary schools to elementary and basic schools (although the latter category features quite wide variation in the proportion of baseline wage bill received): median secondary school receives $94 \%$ of its baseline wage bill, while for elementary and basic schools this proportion is $107 \%$. Most evening schools are donors (median proportion is 91\% of baseline wage bill). Another finding from Figure 25 is that part of the funds received for financing 'in-depth programs' is used by local authorities for redistribution purposes.

The redistribution can be explicit or implicit. For instance, regulation applied in Riga (which concerns more than a hundred schools) sets a flat rate per a 'normalized' student at $81.4 \%$ of the amount of the state subsidy, but allows up to $15 \%$ in addition for compensation of school administration in schools with less than 500 students, whilst in larger schools the upper bound is $10 \%$. In other words, large schools can get up to $89.5 \%$ of the full subsidy, while smaller ones - up to $93.6 \%{ }^{17}$. In Riga, there is also a special regulation which increases the subsidy by about $20 \%$ for 6 minority schools (Polish, Jewish, Estonian, Lithuanian, Ukrainian and Belorussian, all of them quite small: 100 to 250 students).

While size, type and location are easy-to-understand school attributes, the actual driver of the redistribution is the wage level which would prevail in particular schools in absence of redistribution. Which factors can make a school a 'high pay' or 'low pay' one? Under per-student financing, the ,normal' wage bill depends on the number of students and proportions of various categories of

\footnotetext{
${ }^{17}$ Recall, however, that in Riga, municipal contribution to teacher wage bill more than compensates for the deficit.
} 
students which enter the financing formula with different coefficient (see Section 1); we will refer to these two factors as to size effect and composition effects. School average potential teacher earnings ${ }^{18}$ are determined by composition effects and relevant ratios: the number of students per teacher (gross $\mathrm{S} / \mathrm{T}$ ) and the ratio of non-teaching to teaching staff. All these variables potentially can influence local governments' redistribution decisions. Figure 26 confirms negative correlation between gross S/T and proportion of baseline wage received. One interpretation of this finding is that local governments perform counter-efficient redistribution, punishing schools which are more cost-efficient and rewarding inefficient schools. ${ }^{19}$ Of course they do not think this way.

In fact, there are three decision-making models related to redistribution. The first one is driven by equity (or 'minimum acceptable wage') considerations. Under per-student financing, schools with higher S/T (in particular, larger schools) can pay higher wages; policy makers perceive resulting wage inequality as too strong and/or the low-end wages as too small and re-distribute funds from high $\mathrm{S} / \mathrm{T}$ schools to low S/T ones. Large, urban and secondary schools are more likely to have high $\mathrm{S} / \mathrm{T}$, this is where the patterns observed in Figures 24-25 come from. If justified, these equity consideration call for corrections in the parameters of the financing scheme.

The second model applies to schools which are economically not sustainable but cannot be closed for some good reasons. Examples include the above mentioned minority schools in Riga; some small schools which consistently demonstrate high student achievements or have accumulated valuable experience in integrating special needs students; remote rural schools which do not have near-term substitutes for logistical reasons. While some of these cases indeed need special treatment, in other vertical or horizontal integration with larger schools might be an alternative solution. Finally, there is anecdotal evidence that in many cases local policy makers are just reluctant to close or reorganize inefficient schools for political, ideological or personal relations reasons.

Econometric analysis of school level determinants of the received proportion of baseline wage bill is presented in Table 6 which includes four models: for all schools; for schools in republican cities and other urban counties; for schools in urban-rural municipalities; and for schools in rural counties. Another four models refer to the proportion of the extended wage bill received. Explanatory variables include (log) school size, various proportions characterizing student composition, as well as indicators for minority schools and for rural schools. Most of the effects are similar in all models, and in the discussion we refer to specific models only when necessary. All models include municipality fixed

\footnotetext{
${ }^{18}$ Note that one cannot talk about potential earnings per workload, because the actual number of workloads is determined by the actual wage bill.

${ }^{19}$ One can argue that schools whose wage bill was increased as the result of redistribution could hire extra teachers thus lowering the student/teacher ratio (and the other way around); in such cases lower S/T and/or higher ratio of non-teaching to teaching staff are, at least in part, results of (rather the reasons for) redistribution. Although such reversed causality is possible, it is unlikely to generate sizable effects, especially as long as classroom teachers are concerned. However, to avoid endogeneity problem, we do not use the above mentioned ratios for explaining the redistribution decisions but stick to (log) school size. Including the ratios would not substantially increase the explanatory power of the models. For instance, in the first model reported in Table 6 R-squared would only increase from 0.646 to 0.671 .
} 
effects, so that specific circumstances, such as in Daugavpils and Jelgava, do not distort the coefficient of variables of interest.

Other things equal, a $10 \%$ increase in the number of students leads to a decline in the proportion of the baseline wage bill received by 1.3 percentage points on average and by 2.1 percentage points in urban-rural municipalities.

If the policymakers would perceive the built-in composition effects (coefficients) of the financing formula as just, there would be no reason to re-distribute funds between schools based on student composition. In such a case all composition effects in our models ${ }^{20}$ would be not significant. In fact, however, the models confirm redistribution from secondary schools to elementary and basic ones, especially in urban-rural and rural municipalities. Distant students negatively affect the proportion of baseline budget received by school, other things equal. These results suggest that policymakers regard as too high the coefficient 1.25 for upper secondary students and the coefficient 0.82 for distant students. The effect of the integrated special needs students has the same negative sign as in the municipal level models; it looks like a licensed special needs program makes it more likely for a school to be a donor rather than a recipient (this effect is significant only in urban-rural counties).

In urban-rural counties, there is also a redistribution based on the language of instruction: Russian schools receive by 15 percentage points smaller proportion of the normal wage bill than otherwise similar Latvian schools. Note that this concerns only 9 Russian schools, because no such effect is found in urban and rural municipalities where other 96 minority schools are located.

The effect of the in-depth programs is of course positive in baseline wage bill models. However, when extended wage bill (adjusted for these programs) is considered, schools in urban or urban-rural municipalities which run such programs receive (other things equal) a significantly smaller share of the normal wage bill (elasticity is about -0.1 , see Table 6, panel B). In other words, schools which claimed in-depth programs have seen their wage bill increased but less than in proportion to the normalized number of students.

School level models with municipality fixed effects have substantially higher explanatory power than municipal level models: in the baseline wage bill models, R-squared is 0.64 for all schools, 0.72 for schools in urban-rural counties, 0.58 for rural counties, and 0.42 for urban ones. This, however, leaves enough room for school level heterogeneity.

The extent and patterns of redistribution of the state funding between schools performed by local governments suggest that evaluation of the design of the financing scheme should be based on simulated teacher earnings in absence of redistribution (rather than actual earnings). This approach is pursued in (Hazans, 2010).

\footnotetext{
${ }^{20}$ Except for the coefficients of in-depth programs in the baseline wage bill models.
} 


\section{Local, school, and individual level determinants of teacher pay}

\subsection{Data}

In this section we use the payroll data which refer to April, 2010 and cover 829 out of 877 general education schools, including 820 out of 838 municipal schools and include 41837 records; if a teacher has several jobs or performs several significantly different tasks (in the same school or in different schools), there is a separate record for each job/task. For instance, if deputy director of a school also teaches some subject, these are different jobs which are recorded separately. If a secondary school teacher teaches two different subjects in the same school, these are different tasks performed within the same job (post), which are recorded separately. A teacher who teaches in two different schools holds two jobs (posts) in those schools. If the same person is a school psychologist and a librarian in a given school, she/he holds two different jobs in that school, etc.

After combining with the annual school survey and other administrative data, the dataset includes, for each record, a person identifier, experience in teaching occupation in years, job (task) title, number of workloads carried, compensation by source of funding (state, municipal or other), as well as school identifier, information on the school (school type, location, language of instruction, number of students, teachers and workloads, students' distribution by grade and language of instruction, etc.), name and type of municipality. With very few exceptions, the records include also teacher's gender, level of education, and, for classroom teachers, subject taught and a breakdown of the hours worked by function (teaching, preparation, homework correction, etc.).

Descriptive statistics on teachers' school and personal characteristics used in econometric analysis are presented in Table 7.

\subsection{Econometric framework}

Under per-student financing scheme described in Section 1, state-funded part of school's 'normal' wage bill per normative student is fixed and differs only between schools located in republican cities and other schools (see (3) and (4)). Wage bill per real student, WB/S, however, will depend also on the normative-to-real students ratio in the school, which is determined (directly) by the grade composition of students, shares of evening and special needs students, and (indirectly) by school type, reputation, choice of the study programs, and local demographic trends: $W B / S=K\left(\mathbf{Z}_{\mathrm{s}}, \mathbf{V}_{\mathrm{m}}, \xi_{\mathrm{s}}\right)$, where $S$ is the number of students in the school, vectors $\mathbf{Z}_{\mathrm{s}}$ and $\mathbf{V}_{\mathrm{m}}$ include above mentioned observed school and municipality characteristics, and $\xi_{\mathrm{s}}$ is unobserved school specific effect. As documented in Section 3.5, actual wage bill differs from the 'normal' one due to redistribution performed by local governments; regulations require that redistribution is based on observed school characteristics, hence the ratio of actual to 'normal' wage bill can be written as $c_{m}\left(\mathbf{Z}_{\mathrm{s}}\right)$. Taking into account that 
compensation for administrative and support staff is a fixed proportion ${ }^{21} p_{m}\left(\mathbf{Z}_{\mathrm{s}}\right)$ of the total statefunded wage bill, school average teaching-related earnings per teacher in school $s$ located in municipality $m$ thus can be written as $W_{s}=\left(1-p_{m}\left(\mathbf{Z}_{\mathrm{s}}\right)\right) \times c_{m}\left(\mathbf{Z}_{\mathrm{s}}\right) \times K\left(\mathbf{Z}_{\mathrm{s}}, \mathbf{V}_{\mathrm{m}}, \xi_{\mathrm{s}}\right) \times(S / T)$, where $S / T$ is the number of students per classroom teacher (referred to as 'gross $S / T$ ' throughout the paper) ${ }^{22}$. Thus, the per-student financing scheme implies a positive causal effect of gross $\mathrm{S} / \mathrm{T}$ on teacher earnings; the size of the effect is unclear a priori, as some components of $\mathbf{Z}_{\mathrm{s}}$ likely correlate with $\mathrm{S} / \mathrm{T}$. There is also a positive causal effect of net $\mathrm{S} / \mathrm{T}$ on teacher earnings, as gross $\mathrm{S} / \mathrm{T}$ is the product of net $\mathrm{S} / \mathrm{T}$ and the average teacher workload.

Some of our main results will be related to these effects, so before proceeding we discuss whether the student-teacher ratio can be considered exogenous to earnings. This is clearly the case for models (described in Section 4.3) which use as explanatory variables municipality level S/T. When the school level S/T is used (as in Sections 4.4, 4.5), one can argue that principals of schools with higher average earnings tend to hire more teachers (thus reducing gross $\mathrm{S} / \mathrm{T}$ ) and/or make classes smaller or otherwise increase the compensated workload (thus reducing net $\mathrm{S} / \mathrm{T}$ ), so that $\mathrm{S} / \mathrm{T}$ is endogenous (as is average class size). This effect is opposite to the main causal effect of $\mathrm{S} / \mathrm{T}$ on earnings, which therefore will be overestimated. For the models with gross S/T (reported in Tables 8, 9), the relative size of the bias is likely negligible. In fact, an increase in wage bills by 33\% in January 2010 reduced gross S/T just by 0.3 (or by 3\%) on average (Table 2, panel B); simple calculation suggests that estimated coefficients on S/T, which are of magnitude about 0.01 in Table 8 and about 0.02 in Table 9, are overestimated by about $1 \%$ and $2 \%$, respectively. In models with net $\mathrm{S} / \mathrm{T}$ (specifications $3 \mathrm{a}$, 3b of models $\mathrm{D}, \mathrm{E}$ in Table 10) the coefficients on net S/T might be overestimated by about $15 \%$, but this does not compromise our claim that these coefficients are smaller than the [unbiased] respective coefficients in model C.

Individual teacher earnings of course depend also on teacher characteristics. Relevant characteristics which are available (observed) in the data include experience as a teacher (in years), gender, completed education level ${ }^{23}$, main task performed in the school (we distinguish 5 categories: classroom teachers, administration, support staff, interest group teachers, and pre-school staff), number of workloads carried by the teacher, and whether the given school is the teacher's main job; for classroom teachers - also main subject taught. Unobserved teacher characteristics, such as quality of teaching will be reflected by the random error part of the model. Moreover, as discussed in Section 3.2, individual wage rates and earnings depend on strategies followed by school principals and on recommendations by the local education authorities, i.e. on school-specific and municipality-specific effects.

\footnotetext{
${ }^{21}$ The $10 \%$ proportion mentioned in Section 1 is respected by most municipalities, yet some (including Riga) vary it by school size.

${ }^{22}$ When total rather than state-funded wage bill is considered, $c_{m}\left(\mathbf{Z}_{\mathrm{s}}\right)$ and $\xi_{\mathrm{s}}$ are to be modified to account for the municipal contribution (which is county specific but can vary by school.

${ }^{23}$ Most teachers have higher education, but about $4.5 \%$ are still studying, reporting secondary general or secondary professional education.
} 
To sum up, teacher's $i$ compensation $w_{\text {is }}$ for work in school $s$ located in municipality (city or county) $m$ can be modeled as follows:

$$
\log \left(w_{\text {is }}\right)=\alpha+\mathbf{X}_{\mathrm{i}} \boldsymbol{\beta}+\mathbf{Z}_{\mathrm{s}} \gamma+\mathbf{V}_{\mathrm{m}} \boldsymbol{\delta}+\mu_{\mathrm{m}}+v_{\mathrm{s}}+\varepsilon_{\text {is }}
$$

Here $w_{\text {is }}$ might measure any of the following: total earnings, total teaching-related earnings or total state-funded earnings in the given school; total or only state-funded earnings per workload in all jobs/tasks in the given school ${ }^{24}$; earnings per workload only for teaching in the given school; earnings per workload only for contact teaching hours in the given school; 'Earnings' are gross monthly earnings. Row vectors $\mathbf{X}, \mathbf{Z}$, and $\mathbf{V}$ include above mentioned teacher, school and municipality characteristics, respectively; $\beta, \gamma$ and $\delta$ are vectors of coefficients to be estimated along with constant $\alpha$ and parameters of the random part of the model; $\varepsilon_{\text {is }}$ is observation level random error; $\mu_{\mathrm{m}}$ and $v_{\mathrm{s}}$ are municipality and school specific random effects which have zero means and are uncorrelated with each other and with $\varepsilon_{\text {is }}$. Note that the model might include also municipality and/or school specific fixed effects as parts of terms $\left(\mathbf{Z}_{\mathrm{s}}\right)^{\prime} \gamma$ and $\left(\mathbf{V}_{\mathrm{m}}\right)^{\prime} \boldsymbol{\delta}$ in (5).

The models discussed further are meant to shed light on the following questions:

(A) How are teacher earnings per workload (or per contact hour) related to efficiency indicators, such as student/teacher ratio and class size?

(B) How are teacher earnings per workload, as well as total monthly earnings, related to observable school and teacher characteristics?

We will use the econometric framework known as linear mixed models or hierarchical models ${ }^{25}$, as well as population averaged approach (Zeger, Liang, \& Albert 1988) to panel data and, more general, to common effects models. These methods, in contrast with the 'classic' fixed effects and random effects methods for panel data, allow to include in the models both time invariant variables (including fixed effects) and random effects, and do not require an assumption that random effect are not correlated with the explanatory variables ${ }^{26}$.

Equation (5) generates a variety of models either by restricting the sample to some category of teachers (e.g. classroom teachers, administrative staff, or teachers working full-time in the given school) or by including extra variables, such as indicator of the main subject taught (for classroom teachers). Here we restrict the discussion to earnings of school staff members whose main function in the given school (defined as the one with the largest workload) is teaching. Special, board, and private

\footnotetext{
${ }^{24}$ When the earnings per teaching workload (rather than total earnings) are of interest, the net S/T (number of students per teaching workload) enters the equation instead of gross S/T; however, the net S/T can be decomposed into a product of the gross $\mathrm{S} / \mathrm{T}$ and the inverse of the school average number of teaching workloads per classroom teacher, a variable which we will consider as a part of school specific effect; hence we use gross $\mathrm{S} / \mathrm{T}$ as explanatory variable in all models.

${ }^{25}$ See e.g. Rabe-Hesketh \& Skrondal (2005); Greene (2008: 233-238).

${ }^{26}$ Mixed models allow for some of the coefficients in $\beta, \gamma$ and $\delta$ to include random effects, i.e. to vary across observations or groups of observations (for instance, schools). These results are not included in the current version of the paper.
} 
schools are excluded. Due to space limitations, only the situation after the increase of financing in January 2010 is considered.

Table 8 presents 6 specifications of mixed models, all of which include random municipalityspecific effects, as well as random school effects. Alternative specifications with population averaged random effects produce very similar results which are available on request. Except for [1], all models control for the main subject taught. Specifications [1] and [2a] exclude evening (part-time) schools, whilst other models include them. Models [1], [2a], [2b], [3] consider only teaching-related earnings, ignoring other tasks (this implies that in fact only state-funded earnings are included, as the share of other sources in compensation for teaching in grades 1-12 is negligible, see Figure 20, middle chart). The first three specifications deal with earnings per workload. Specification [3] looks at earnings per contact hours and aims to shed light on differences in earnings across subjects taught due to different allocation of paid hours for complementary tasks. Models [4] and [5] consider, respectively, statefunded and total earnings per workload from all jobs/tasks in the given school. Finally, model [6] looks at total monthly earnings in the given school. While earnings per workload are, in principle, comparable across all teachers (including those working part-time), teachers, which have less than one full workload in the given school or work in more than one school, are excluded from the monthly earnings model. Thus, we have about 18600 observations in each of the specifications [1]-[5] and about 12500 observations in specification [6].

Table 9 looks at the determinants of full-time teacher's earnings from all jobs and schools. Here 'full-time' means that person's total workload in all jobs/schools is no less than 1 full workload. Specifications [1]-[3] (based on more than 14000 observations) deal with classroom teachers (as of main job); the first two analyze only compensation for teaching-related tasks, while [3] covers compensation for all tasks. Last two specifications cover all full-time teachers (about 17000 observations); one analyzes only state-funded earnings, but the other includes also earnings funded by local governments or from other sources. Note that when modeling total monthly earnings (i.e. in Table 9 and col. [6] of Table 8), the number of workloads (or hours worked per week) is not controlled for, because we want to see school and teacher characteristics' overall effect on earnings through all channels, including the workload. Results are described in detail in the following sub-sections.

\subsection{Teachers' pay and efficiency before and after the reform}

Before the reform, due to input-based financing combined with specific regulations which allocated the same number of hours for homework correction and class supervision for class size between 16 and 25 students, schools had financial incentives to increase number of classes (given the number of students) and hence to lower the student-teacher ratio. As the result, teachers' earnings per workload were negatively related to the student-teacher ratio. 
According to a model (see Table 10, col. [1a]) based on teacher level data (a representative sample $^{27}$ with $\mathrm{N}=832$ full-time teachers with completed higher education), which controls for gender, age, ethnicity, tenure, job category (secondary school teacher, primary school teacher, and other teaching professionals ${ }^{28}$ ) and school size (proxied by the number of employees), in the pre-reform period between January 2008 and August 2009, an increase in the city/district level student/(teaching workloads) ratio (i.e., net $S / T$ ) by one unit resulted in a decline in the teacher's net hourly earnings at the main job by $5 \%$ (significant at $1 \%$ level). Note that the same result holds for earnings per workload, because one workload is equivalent to fixed, within each job category, number of hours (21 for classroom teachers).

After introducing per-student financing, the incentive structure has changed from counter-efficient to pro-efficient. In the spring 2010, according to models (with almost identical control variables as above) based on full coverage ${ }^{29}$ school-teacher level payroll data (see Table 10, col. [3a], Models A E), earnings per workload are positively related to the net student-teacher ratio ${ }^{30}$. The size of the effect is maximal (and matches exactly the size of the opposite pre-reform effect, i.e. $5 \%$ per unit of $S / T$ ) when the student-teacher ratio is measured at the level of new municipalities (Model C). This makes sense, because it is the level to which money follows student. School level student/teacher ratio also has a significant positive effect, but its estimated size is much smaller: $2.75 \%$ per unit change in $S / T$ (Model D; as argued in Section 4.2, actual size might be even smaller due to endogeneity of S/T in models $\mathrm{D}$ and $\mathrm{E}$ ); this is consistent with the fact that municipalities redistribute funds from high $\mathrm{S} / \mathrm{T}$ schools to low S/T ones (see Section 3.5), thus weakening the correlation between school level efficiency and teacher compensation. On the other hand, when the student teacher ratio is measured at the old municipality level (i.e., as in the pre-reform model), the effect is also weaker but still sizable (2.28\% per unit of $S / T$ ) and statistically significant (Model B). The effect declines further (remaining significant though) when student/teacher ratio is measured using September school census (rather than the current payroll) data on the number of teaching workloads (Models A and E).

Interestingly, immediately after the reform (before the increase in per-student financing in 2010) teacher earnings per workload were still negatively related to net $\mathrm{S} / \mathrm{T}$ measured at the old municipality level (Table 10, col. [2a], Models A, B); when S/T is measured at the new municipality level or at the school level, the effect is positive but weak ( $0.3 \%$ per unit change in $S / T$, see Models C and E) and significant only in one out of three specifications. The reasons are two-fold. First, because the level of per student financing was extremely low, earnings per workload have been compressed near the lower legal limit (Figure 20). Second, as already mentioned in Section 3.5, the counter-efficient

\footnotetext{
${ }^{27}$ The data come from teachers' sub-sample of the Labour Force Survey, augmented with city/district level administrative data on number of students, teachers and teachers' workloads.

${ }^{28}$ We have excluded special school teachers for better comparability with the post-reform results; when they are kept in the sample (which makes $\mathrm{N}=900$ ) or, alternatively, when only classroom teachers are included ( $\mathrm{N}=798$ ) the effect is just slightly weaker: $4.6 \%$ (significant at 5\% level, see Table 10, col. [1b]).

${ }^{29}$ Special, board, and private schools, as well as school directors and deputy directors are excluded.

30 This is also true for the gross student-teacher ratio (see Table 8, col. [1]-[5]).
} 
redistribution performed by the local governments has been more pronounced before the January increase in financing (Figure 24, bottom chart).

Results are similar when compensation for non-teaching tasks is excluded and only classroom teachers (as of main job in the school) are considered (Table 10, col. [1b], [2b], [3b]). We have chosen this case for graphical presentation (Figure 27), as it refers to a homogenous category of school staff with identical number of hours per workload, and comparison between the periods is not affected by the changes in the proportion of non-teaching staff.

To sum up, a switch from a counter-efficient to pro-efficient remuneration system is certainly one of the reform's achievements; it did not work, however, while the level of per-student financing was too low (in September - December 2009). Moreover, the full effect of school-level cost efficiency on teacher earnings is not revealed yet because of the redistribution of funds between schools performed by local governments.

\subsection{School level determinants of teacher earnings}

This subsection analyzes how teacher earnings per workload, per contact hour, and total monthly earnings depend on school location, as well as class size, composition of students by level (primary, lower secondary and upper secondary), type of program (standard full-time, evening/distant or special needs program) and language of instruction. Results related both to state-funded and to total earnings are presented. Recall that special, board, and private schools are excluded from consideration, because they are financed via separate schemes.

We start with the school location. In the republican cities, full-time teachers' state-financed monthly earnings in a given school are by $9 \%$ less then earnings of teachers in otherwise similar (in terms of student-teacher ratio, class size, students' composition by grade and instruction language) schools in other cities (Table 8, col. [6]). Moreover, when one takes into account earnings in all schools $^{31}$, teachers in the republican cities earn (from state budget) 15 to $16 \%$ less than their otherwise similar counterparts in other cities (Table 9, col. [3], [4]) (2) $^{32}$

Other things equal, classroom teacher state-funded earnings per workload from teaching in the republican cities are also lower than in small cities; the difference is 5 to $6 \%$ (Table 8, col. [1], [2a], [2b]), and earnings per contact hour are by 7\% lower (Table 8, col. [3]).

Classroom teachers in rural schools earn about $2.6 \%$ less per month than teachers in otherwise similar (in terms of student-teacher ratio, school type and students' composition by grade and instruction language) schools in small cities (Table 8, col. [6]); when earnings in all schools are considered, this gap reaches 5 to $6 \%$ (Table 9, col. [1]-[5]) ${ }^{33}$. Rural teachers' earnings per workload

\footnotetext{
${ }^{31}$ Recall that $10.2 \%$ of teachers in republican cities, $14.4 \%$ in other cities and $12.8 \%$ in rural areas work in more than one school (Table 5). We classify teachers by type of settlement according to location of their main job.

${ }^{32}$ When local funding is included, the gap is $12 \%$, see Table 9, col. [5]. On average (for all school staff members carrying in total at least one full workload), teacher state-funded earnings from all jobs in republican cities are by $14 \%$ lower than in other cities, whilst for classroom teachers this gap is $10 \%$.

${ }^{33}$ On average, rural teachers' state-funded earnings from all jobs are by more than $20 \%$ lower than those of teachers in small cities (and by 11\% lower than in the republican cities).
} 
are not significantly different than those of small cities' teachers after controlling for other factors (Table 8, col. [1], [2a], [2b], [4], [5]), but earnings per contact hour are by $4 \%$ lower in rural schools than in small cities (Table 8, col. [3]).

Both gross student-teacher ratio and average class size in the school have positive and significant effect on teacher earnings per workload, as well as on total monthly earnings. When both variables enter the models, a unit increase in either gross $\mathrm{S} / \mathrm{T}$ or class size raises earnings per workload by $0.6 \%$ to $1 \%$, other things equal (see Table 8, col. [1]-[5] for details); the effects on total monthly earnings of classroom teachers working fill-time are $0.5 \%$ for class size and 3.5\% for gross $\mathrm{S} / \mathrm{T}$ (Table 8 , col. [6]). As argued in Section 4.2, both these variables are likely endogenous to earnings, and their effects are overestimated, but relative bias in estimated coefficients on gross $\mathrm{S} / \mathrm{T}$ is negligible. Likewise, using the fact that a 50\% cut in teacher earnings between September 2008 and September 2009 led to an increase in average class size by 0.8 students (or by $4.7 \%$, see Table 2, panel B), one can argue that bias in class size effects in Tables 8, 9 is also negligible. Gross S/T and class size are of course positively correlated, so when class size is not controlled for, the effect of gross $\mathrm{S} / \mathrm{T}$ becomes stronger, as shown in the bottom panel of Table 8, which also reports earnings elasticities with respect to the school level gross S/T: 0.14 for earnings per workload, 0.22 for earnings per contact hour, and 0.39 for total monthly earnings. Under per-student financing, one would expect the latter elasticity to be close to 1 in absence of redistribution.

We now turn to student composition. For readers not interested in details, here are some hints on interpretation of the coefficients. The first three variables under the heading "Share of students in:" (grades 1 to 4 , grades 10 to 12 (day programs), and evening or distant programs), together with omitted category - students in grades 5 to 9 (day programs), sum up to 1 . Hence, significantly positive (respectively, negative) coefficients indicate categories which are, under given coefficients in the financing scheme and given redistribution policies, more (respectively, less) beneficial for the school from the teacher earnings perspective than students in grades 5 to 9 (day programs); note that meaning of 'earnings' varies from column to column. Three coefficients are also comparable to each other - a larger coefficient indicates a more beneficial category.

Three other variables (shares of students in minority programs ${ }^{34}$, special needs programs ${ }^{35}$, as well as professionally oriented programs with in-depth study of specific subjects) have a slightly different interpretation, because these categories overlap with the above mentioned four categories. For minority programs, the value of the variable in most cases is either 0 (Latvian schools) or 1 (Russian and other minority schools), although there are also some mixed schools. Thus, respective coefficients show (roughly) the difference in earnings between Russian and Latvian schools, other things equal. Finally, positive coefficients on special needs and in-depth programs indicates that having such programs in a school, under given coefficients in the financing scheme and given

\footnotetext{
${ }^{34}$ Programs with instruction in Russian or other minority languages.

${ }^{35}$ Including special needs students integrated into standard programs.
} 
redistribution policies, have a positive effect on teacher earnings (per workload or per month, depending on specification).

When only state funded compensation for teaching is considered (Table 8, col. [1] - [3]), there is no significant difference in classroom teachers' earnings per workload or per contact hour depending on the share of students in grades 1 to 4 vs. grades 5 to 9 (other things equal).

Teachers working in schools with larger proportions of full-time upper secondary students have a statistically significant advantage over other teachers in terms of earnings per teaching workload (Table 8, col. [1], [2a], [2b]), but especially in terms of earnings per contact hour and total monthly earnings (Table 8, col. [3], [6]; Table 9, col. [1]-[5]).

Teachers in state gymnasia (grammar schools) have a 7 to $8 \%$ advantage over similar teachers in otherwise similar secondary schools without such status, in terms of earnings either per month or per workload (Table 8).

Classroom teachers in minority schools earn almost $4 \%$ less per contact hour and 7 to $8 \%$ less per month than otherwise similar teachers in Latvian schools; this is true for both state funded and total earnings, either in the given school or in all schools/jobs (Table 8, col. [3], [6]; Table 9, col. [1] - [3]). For all teachers, the gap is $5 \%$ for state-funded and $8 \%$ for total earnings (Table 9, col. [4] - [5]). The gap in average total earnings (in all schools/jobs) of classroom teachers between Russian and Latvian schools is $8 \%$ in republican cities and $12 \%$ in other cities (Figure 28). Note that there is no difference in earnings per workload, so the immediate reason for the gap is smaller number of workloads available in Russian schools. But why is it so, is not completely clear. Smaller municipal contribution to teacher compensation in Russian schools in Riga (Table 5) and some redistribution of the state subsidy in favor of Latvian schools in urban-rural counties (Table 6) explain only part of this effect ${ }^{36}$. Given that most Russian-language schools are in big cities, this overlaps with the negative big city effect, so a teacher in a school with instruction in Russian located in one of the republican cities earns (in the given school) 5\% less per workload and 15\% less in total than a teacher in otherwise similar Latvian school located in a small city. When earnings in all schools are included, the gap is even larger. On average, when all urban schools are considered, full-time teachers working only in school/schools with instruction in Russian earns per month $11-12 \%$ less than teachers in Latvian schools (see Figure 28).

Students in evening or distant programs in day schools are slightly 'more beneficial' than students in upper secondary grades of day programs in terms of classroom teacher earnings per workload or per contact hour (Table 8, col. [1], [2a]) and equally beneficial in terms of total teaching-related monthly earnings of full-time teachers in all jobs/schools, although generate less earnings for non-teaching tasks (Table 9, col. [1] - [3]).

Coefficients on shares of students in special needs (respectively, in-depth) programs are positive and significant in all models of earnings from teaching (respectively, all models) in Tables 8-9,

\footnotetext{
${ }^{36}$ Plausibly, there are some extra functions, tasks and/or program elements in Russian/minority schools which are not reflected in the coefficient system but prevent teachers from taking on extra load.
} 
indicating that such programs positively affect teacher earnings per workload, per contact hour and per month. For an average teacher, these shares are about 0.01 and 0.05 , respectively (Table 7), so the effects on earnings are fairly small; however, in a school where, say, $40 \%$ of students are claimed to study in-depth programs (which is the case for $5 \%$ of teachers) the predicted increase in total monthly earnings is $4 \%$.

\subsection{Individual determinants of teacher earnings}

Recall that for every staff member our data provides information on gender, educational attainment and work experience (as a teacher) - these are commonly used explanatory variables in earnings models. In addition, for every school the where the teacher is employed, the data include an indicator the job being primary one ${ }^{37}$, the number of contact hours in every subject taught, as well number of paid hours spent performing non-teaching tasks. This allows classifying classroom teachers according to main subject taught. Subject effects, however, are not discussed in this paper.

All models of earnings per workload predict maximum at 14-15 years of experience, while earnings per contact hour and total monthly earnings seem to peak at 10-11 years of experience. More importantly, returns to experience are, on average, very modest: predicted total earnings at 11 years of experience exceed those at the beginning of the career by no more than 5\%. For comparison, in most OECD countries teachers' statutory salaries vary strongly with experience: on average, salary at top of scale exceeds starting salary by more than 70\% (see OECD 2009: Table D3.1).

Just 3\% of classroom teachers have not completed higher education (mostly, these are senior students). Their earnings per workload are 1 to $2 \%$ lower, but total monthly earnings - 8 to $9 \%$ lower than those of teachers with a university degree (Tables 8-9).

Male teachers are quite rare in Latvian schools: just $11 \%$ of all classroom teachers are male, and this proportion falls to $7 \%$ among full-time teachers. After controlling for other characteristics, including main subject taught, their state-funded teaching-related earnings per workload and statefunded total earnings are hardly different from those of female teachers (Table 8, col. [1], [2a], [2b]; Table 9, col. [2]-[3]); total earnings per workload are $2 \%$ higher, but total monthly earnings - $2 \%$ lower in the given school (Table 8, col. [5], [6]) and by 6\% lower if earnings in all schools/jobs are accounted for (Table 9, col. [1]).

Perhaps the most interesting feature of all estimated models is the high degree of individual heterogeneity: after controlling for all above mentioned school and personal characteristics, including subject taught, on top of county level and school level random effects, residual standard deviation is as big as 0.08 to $0.10 \log$ points for wage per workload and 0.20 to $0.22 \log$ points for total monthly earnings.

\footnotetext{
${ }^{37}$ In other words, given school is officially the main employer of this person.
} 


\section{Conclusion and policy recommendations}

This paper documents the reform of teacher compensation and optimization of school network, which occurred in Latvia amidst the economic crisis of 2008-2010, immediately after territorial reform and municipal elections. Starting from school year 2009/2010, input-based financing of teacher salaries has been replaced, at the municipality level, by per-student financing. As before, this financing comes in the form of earmarked grants from central budget to local governments, but due to general fiscal tightening, it has been cut roughly by half in September 2009, following though by a one third increase in January 2010. Almost 60\% of schools report under-financed study programs in SeptemberDecember 2009. The January increase in funding allowed addressing the problem of under-financed programs to a large extent, but even after that more than $20 \%$ of schools are under-financed. As expected, introduction of per-student financing resulted in significant efficiency gains: average class size went up by almost 5\%, number of students per teacher post - by 7\%, and number of students per teaching workload (the net student/teacher ratio) - by $13 \%$.

Apart from efficiency gains, the reform has triggered positive developments in two other areas: incentives in the teacher compensation system and school autonomy. Before the reform, schools had financial incentives to increase number of classes (given the number of students) and hence to lower the student-teacher ratio. As the result, teachers' earnings per workload were negatively related to the municipality-level student-teacher ratio. After the reform, this effect has changed its sign: the compensation system is now pro-efficient.

Transition to per-student financing has been accompanied by lifting regulations on class size and on the number of administrative and support staff members, and by relaxing substantially regulations on compensated hours for complementary instructional tasks, allowing school directors (or local governments, if they intervene) to use available funds as they find fit. This is an important step in the right direction, in line with well-established in the literature findings that "school autonomy in personnel and process decisions can be beneficial for student learning, at least in systems where external exit exams introduce accountability” (Wößmann and Schütz 2006; note that Latvia has a centralized exit examination system); recent results by Lavy (2009: p.25 and Table 10) also suggest that 'school autonomy in personal and budgetary issues' enhances student achievement. Note that before the reform Latvian schools were heavily over-regulated; World Bank (2007), Rural Schools' Support Group (2009), and the previous version of this paper have all argued for lifting most process regulations.

Apart from school autonomy, another policy with the potential to increase efficiency in the school system is introduction of performance-related pay for teachers (see Wößmann and Schütz 2006 and references therein). Wößmann and Schütz (2006) report improvements in student performance which derive from changes in teaching methods, after-school teaching and increased responsiveness to students' needs. In this study, we provide evidence for a substantial incidence of using performancerelated criteria for teacher base salary differentiation: $15 \%$ of schools report differentiation based on 
teacher reputation, quality of work and innovation, students' exam results and special achievements, and the same proportion takes into account teachers' extra activities in the school. Note that such practices are yet to become common also on OECD member and partner countries ${ }^{38}$. So, Latvian schools seem to be quite innovative in this respect. Overall, half of Latvian schools vary base salary by at least $4 \%$, almost a quarter of schools - by at least $10 \%$, and one in ten schools - by $30 \%$ or more; only a small part of this variation is related to experience. Furthermore, both base salaries and gross monthly earnings of teachers vary strongly across schools. Both average earnings and between-school variation in earnings are increasing with school size, thus creating financial incentives for consolidation.

Notwithstanding the reform's achievements, several problems in its implementation await solutions. Under current design of the per-student financing, local governments can use their own rules to redistribute funds across existing schools. Such a possibility, in our opinion, undermines the very idea of the per-student financing and has a potential to kill directors' motivation to improve their schools beyond the level which guarantees survival. Due to redistribution, elasticity of teacher monthly earnings with respect to the school level gross student/teacher ratio is just 0.39 , while in absence of redistribution one would expect elasticity close to 1 . Moreover, in cases of urbanrural municipalities possibility of redistribution might undermine motivation of the local governments to close inefficient schools if they can keep them alive by taking some money from larger urban schools. Thus, the money should go first to the local governments, to give them possibility to decide on school closures and consolidations when necessary; after the deadline for such decisions (March 1 of each year), the money should follow to schools proportionally to the normalized number of students, with very few exceptions which require special treatment.

The arguments above only work if the design of the per-student financing is equitable, i.e. does not imply unjustified differences in compensation between different schools. This is not the case for the current scheme (which can be explained by the urgency with which it has been designed amid the crisis). A range of findings of this study suggest that current system strongly favors schools in small towns compared to all other schools, but especially to schools in the republican cities. For most teachers working in small towns, density of the student population is in the same range as in the republican cities, while the state funding per student is by $27.5 \%$ higher. Other distortions in the current scheme are found in Hazans (2010).

Faced with distortions in the original design, municipalities deviate from it when allocating funds to schools. We find clear evidence that municipalities redistribute funds from big schools to small ones, from schools located in towns to rural schools, and from secondary schools to elementary and basic schools (although the latter category features quite wide variation in the proportion of baseline wage bill received). Underlying pattern is that funds are taken from schools with high student/teacher

\footnotetext{
${ }^{38}$ Only in 10 out of 37 of these countries performance-based criteria are used for decisions on base salary, and only in 5 countries these decisions are made at the school level (OECD 2009: Tables D3.3a, D3.3b). Lavy (2009: p.23), based on PISA 2006, reports that only 29\% of schools in OECD used student achievement in teacher evaluation.
} 
ratio and given to those with low student/teacher ratio. In other words, local governments perform counter-efficient redistribution.

In some cases this redistribution is driven by equity (or 'minimum acceptable wage') considerations; corrections in the system design should reduce the number of such cases to a minimum.

Another model of redistribution applies to schools which are economically not sustainable but cannot be closed for some good reasons (for instance, being unique in some sense, or providing education of extraordinary quality). While some of these cases indeed need special treatment, vertical or horizontal integration with larger schools might be an alternative solution, which will create economies of scale and provide some control (and hence incentives) to the management of the donor schools. On the other hand, one can think about creating a legal framework which would allow parents to co-finance school maintenance expenditures (currently covered by municipalities) for a small but 'very good' school if they do not want it to be merged with a larger one. One more consideration which should be taken into account is that consolidation of the school network should not eliminate school competition and school choice, both of which usually have a positive effect on student achievements (Gibbons, Machin, and Silva (2008); Bayer and McMillan (2010); Lavy (2010) among others). In Latvia, number of schools in some municipalities is too small to provide either choice or a competitive environment, hence using functional overlapping and competing jurisdictions (Frey and Eichenberger (2006); Reiljan and Friedrich (2010)), which coordinate use of educational resources and pool some of them, should be considered. In fact, many of the new municipalities have created educational authorities responsible for several municipalities, but all financial decisions are still made separately.

\section{References}

Baicker, Katherine and Gordon, Nora (2006). The effect of state education finance reform on total local resources, Journal of Public Economics, 90 (8-9): 1519-1535.

Ballou, Dale (2001). Pay for performance in public and private schools. Economics of Education Review, 20 (1): 51-61.

Bayer, Patrick J. and McMillan, Robert (2010). Choice and competition in education markets, Economic Research Initiatives at Duke (ERID) Working Paper No. 48. Available at SSRN: http://ssrn.com/abstract=1601325

BenDavid-Hadar, Iris and Ziderman, Adrian, A new model for equitable and efficient resource allocation to schools: The Israeli case. IZA Discussion Paper No. 4822.

Billger, Sherrilyn M., Demographics, Fiscal health, and school quality: Shedding light on school closure decisions. IZA Discussion Paper No. 4739. 
Bu, Zizhou, Wang, Youqiang and Hou, Yilin (2010), Central financing, sub-central redistribution, and funding adequacy in heterogeneous localities - evidence from China's recent reform .

Available at SSRN: http://ssrn.com/abstract=1596289

EACEA P9 Eurydice (2009). Key Data on Education in Europe 2009. Brussels: EC.

Frey B. S.; Eichenberger R. (2006). Functional overlapping and competing jurisdictions (FOCJ): A component and alternative to today's federalism, in Ahmal Etisham and Giorgio Brosios (eds) Handbook of Fiscal Federalism. Amsterdam: Elgar pp. 154-181.

Gibbons, Stephen, Machin, Stephen and Silva, Olmo (2008). Choice, competition and pupil achievement, Journal of European Economic Association, 6 (4): 912-947

Gordon, Nora, and Knight, Brian (2008). The Effects of School District Consolidation on Educational Cost and Quality, Public Finance Review, 36(4), pp. 408-430.

Greene, William H. (2008). Econometric Analysis. 6th Ed. Upple Saddle River: Pearson Prentice Hall.

Hazans, Mihails (2010), Teachers' pay, class size, and local governments: A reform amidst the crisis, Background study for the World Bank (2010) Republic of Latvia Public Expenditure Review.

Kenny, Lawrence W., and David A. Denslow, Jr. (1980). Compensating differentials in teachers' salaries. Journal of Urban Economics, 7(2):198-207.

Lavy, Victor (2009). The effect of instructional time on achievements in math, science and reading: Evidence from developed and developing countries. Paper presented at EALE Conference 2010.

Lavy, Victor (2010). Effects of free choice among public schools. Review of Economic Studies 77(3): 1164-1191.

Nir, Adam, and Melly Napcha (2007). Teachers' salaries in public education: Between myth and fact. International Journal of Educational Management, Vol. 21(4):315-328.

OECD (2009). Education at a glance 2009. Paris: OECD, www.oecd.org/edu/eag2009.

Rabe-Hesketh, Sophia and Skrondal, Anders (2005). Multilvel and Longitudinal Modeling Using Stata. College Station, Texas: Stata Press.

Reiljan, Janno and Friedrich, Peter (2010). Strategies in the Fiscal Reform of Estonian General Education. University of Tartu Economics and Business Administration Working Paper No.732010. Available at SSRN: http://ssrn.com/abstract $=1646930$

Republic of Latvia Cabinet of Ministers (2004-2009). Regulations on pedagogical workers' salaries No. 746, 545, 735, 836, 1616.

Rivkin, Steven G., Hanushek, Eric A. and Kain, John F. (2005). “Teachers, Schools, and Academic Achievement.” Econometrica 73(2): 417-58

Rural Schools’ Support Group (2009). A plan to save rural schools (in Latvian). http://news.frut.lv/lv/education/72173

Southwick, Lawrence (Jr), and Gill, Indermit S. (1997). Unified salary schedule and student SAT scores: Adverse effects of adverse selection in the market for secondary school teachers.

Economics of Education Review, 16(2): 143-153 
Stoddard, Christiana (2005). Adjusting teacher salaries for the cost of living: The effect on salary comparisons and policy conclusions. Economics of Education Review, 24(3): 323-339.

Tuck, Bradford, Berman, Matthew and Hill, Alexandra (2009). Local amenities, unobserved quality, and market clearing: Adjusting teacher compensation to provide equal education Economics of Education Review, 28(1): 58-66.

Walden, Michael L. and Newmark, Craig M. (1995). Interstate variation in teacher salaries. Economics of Education Review, 14(4): 395-402.

Walden, Michael L. and Sogutlu, Zulal (2001). Determinants of intrastate variation in teacher salaries. Economics of Education Review, Volume 20(1): 63-70.

World Bank (2007). Background Report for Bank-Fund Technical Assistance Mission on Public

Expenditure Review and Public Finance Management Issues in Latvia (unpublished).

Wößmann, Ludger and Gabriela Schütz (2006). Efficiency and Equity in European Education and Training Systems. Analytical Report for the European Commission. http://www.eenee.de/portal/page/portal/EENEEContent/_IMPORT_TELECENTRUM/D OCS/SWP\%20EENEE-Part\%20060426.pdf

Wößmann, Ludger and West, Martin R. (2006). Class-size effects in school systems around the world: Evidence from between-grade variation in TIMSS, European Economic Review, 50(3): 695-736. Zeger, Scott L., Liang, Kung-Yee, and Albert, Paul S. (1988), Models for Longitudinal Data: A Generalized Estimating Equation Approach, Biometrics 44: 1049-1060. 
Table 1 - Teacher remuneration from the state budget before and after the reform

\begin{tabular}{|c|c|c|}
\hline & Before the reform & $\begin{array}{c}\text { After the reform } \\
\text { (since Sept 1, 2009) }\end{array}$ \\
\hline & \multicolumn{2}{|c|}{ School wage bill } \\
\hline & $\begin{array}{l}\text { Given the approved study programs } \\
\text { implemented by the school, the wage } \\
\text { bill is determined mainly by the } \\
\text { number of classes at each grade level } \\
\text { (as well as by approved optional and } \\
\text { interest subjects). }\end{array}$ & $\begin{array}{l}\text { Determined by: (i) the number of students } \\
\text { at grades } 1-4,5-9 \text {, and } 10-12 \text {; (ii) the } \\
\text { number of students in special, advanced, } \\
\text { part-time, and correspondence programs; } \\
\text { (iii) school location ( } 9 \text { republican cities vs. } \\
\text { the rest of the country). }\end{array}$ \\
\hline & \multicolumn{2}{|c|}{ Statutory wage rate $W_{t}$ for one teacher workload (21 hours per week) ${ }^{\text {a }}$} \\
\hline & $\begin{array}{l}\text { At least LVL 340, } 345 \text { or } 350 \text { if } \\
\text { experience is less than } 5 \text { years, } \\
5 \text { to } 10 \text { years or more than } 10 \text { years. } \\
\text { In fact, only the lower limit applied. }\end{array}$ & $\begin{array}{c}\text { At least LVL 245, } 250 \text { or } 255 \text { if } \\
\text { experience is less than } 5 \text { years, } \\
5 \text { to } 10 \text { years or more than } 10 \text { years. } \\
\text { In fact, the wage rates vary significantly } \\
\text { both across and within schools. }\end{array}$ \\
\hline & \multicolumn{2}{|c|}{ Paid hours per week in addition to contact hours } \\
\hline Preparation & 2 & Up to $2^{\text {b }}$ \\
\hline Individual consultations & 2 & Up to $2^{b}$ \\
\hline $\begin{array}{l}\begin{array}{l}\text { Homework and test } \\
\text { correction (mathematics } \\
\text { \& languages) }\end{array} \\
\end{array}$ & $\begin{array}{c}3,4 \text { or } 6 \text { (if class size is } 8 \text { to } 15,16 \text { to } \\
25 \text { or }>25 \text { students) }\end{array}$ & Up to $6^{b}$ \\
\hline $\begin{array}{l}\text { Homework and test } \\
\text { correction (other subjects) }\end{array}$ & $\begin{array}{c}1 \text { hour per week } \\
\text { (sciences, history and geography) }\end{array}$ & $\begin{array}{l}\text { Up to } 1 \text { hour per week }{ }^{b} \\
\text { (all subjects) }\end{array}$ \\
\hline \multirow[t]{2}{*}{ Class supervision $^{\mathrm{c}}$} & $\begin{array}{c}\text { Up to } 4,5 \text { or } 6 \text { hours per week }{ }^{b} \text { (if } \\
\text { class size is up to } 15,16 \text { to } 25 \text { or }>25 \\
\text { students) }\end{array}$ & Up to 6 hours per week ${ }^{b}$ \\
\hline & \multicolumn{2}{|c|}{ Pay supplements } \\
\hline For quality & $\begin{array}{l}\text { Up to } 10 \% \text { (before } 01.01 .2009 \text { ); } \\
\text { Up to } 7 \% \text { in January - June } 2009 \text {; }\end{array}$ & $\begin{array}{c}\text { Up to 7\% } \\
\text { (suspended in 2010-2011 by a special law) }\end{array}$ \\
\hline $\begin{array}{l}\text { Teachers in state } \\
\text { gymnasiums }\end{array}$ & $10 \%$ & $10 \%$ \\
\hline $\begin{array}{l}\text { For split working day } \\
\text { (if teacher's total } \\
\text { workload does not exceed } \\
\text { one full load) }\end{array}$ & $20 \%$ & $20 \%$ \\
\hline $\begin{array}{l}\text { For increased amount of } \\
\text { work (e.g. multiple jobs } \\
\text { within school) }\end{array}$ & $\begin{array}{l}\text { Up to } 50 \% \text { (at the director's } \\
\text { discretion, within given wage bill) }\end{array}$ & $\begin{array}{l}\text { Up to } 20 \% \text { (at the director's discretion, } \\
\text { within given wage bill) }\end{array}$ \\
\hline $\begin{array}{l}\text { For work with special } \\
\text { needs students integrated } \\
\text { in usual classes }\end{array}$ & & $10 \%$ \\
\hline $\begin{array}{l}\text { For work with special } \\
\text { needs in special schools, } \\
\text { classes or hospitals }\end{array}$ & 10 to $20 \%$ & 10 to $20 \%$ \\
\hline $\begin{array}{l}\text { For work in social } \\
\text { correction schools or } \\
\text { classes }\end{array}$ & $30 \%$ & $30 \%$ \\
\hline $\begin{array}{l}\text { Individual bonuses } \\
\text { (within given wage bill) }\end{array}$ & $\begin{array}{r}\text { At the director's discretior } \\
\text { for directors - at the }\end{array}$ & $\begin{array}{l}\text { (according to approved criteria); } \\
\text { ocal government discretion }\end{array}$ \\
\hline & Minimal salary for one administrc & ive workload (40 hours per week), LVL \\
\hline $\begin{array}{l}\text { School size up to } 400 \\
\text { School size } 401 \text { to } 800 \\
\text { School size }>800\end{array}$ & $\begin{array}{l}\text { Director:612-664; Deputy: 494-500 } \\
\text { Director: 695-738; Deputy: 503-539 } \\
\text { Director:782-854; Deputy: 554-598 }\end{array}$ & $\begin{array}{l}\text { Director:447-486; Deputy: 340-361 } \\
\text { Director: 508-539; Deputy: 367-393 } \\
\text { Director: 571-624; Deputy: 404-437 }\end{array}$ \\
\hline
\end{tabular}

Notes: ${ }^{\mathrm{a}} 1 \mathrm{LVL}=1.42$ EUR. ${ }^{\mathrm{b}}$ At school or local government discretion. ${ }^{\mathrm{c}}$ Hours for class supervision are not allocated in board schools, evening schools and social correction schools/classes.

Sources: Cabinet regulations Nr. 746 (before the reform) and Nr. 836 (after the reform). 
Table 2 - Evolution of efficiency parameters in primary and general secondary education, 2007-2010

\begin{tabular}{|c|c|c|c|c|c|c|}
\hline & \multicolumn{6}{|c|}{ A. All schools (as of the beginning of school year) } \\
\hline & \multirow{2}{*}{\multicolumn{2}{|c|}{$\begin{array}{lc} & \% \\
2008 & \text { Change }\end{array}$}} & \multicolumn{4}{|c|}{$\%$} \\
\hline & & & \multicolumn{2}{|c|}{ 2008/2009 } & Change & 2009/2010 \\
\hline Students ${ }^{a}$ & 263140 & $-5.5 \%$ & \multicolumn{2}{|c|}{248647} & $-3.8 \%$ & 239139 \\
\hline Schools & 992 & $-1.0 \%$ & \multicolumn{2}{|c|}{982} & $-10.7 \%$ & 877 \\
\hline Class sets ${ }^{\mathrm{b}}$ & 14399 & $-3.0 \%$ & \multicolumn{2}{|c|}{13971} & $-7.8 \%$ & 12887 \\
\hline Total workloads & 45139 & $1.4 \%$ & \multicolumn{2}{|c|}{45783} & $-28.9 \%$ & 32564 \\
\hline Teaching workloads & 32928 & $1.4 \%$ & \multicolumn{2}{|c|}{33419} & $-24.9 \%$ & 25099 \\
\hline Share of non-teaching workloads & $27.1 \%$ & $-0.1 \%$ & \multicolumn{2}{|c|}{$27.0 \%$} & $-15.2 \%$ & $22.9 \%$ \\
\hline Total school staff (number of posts) ${ }^{\mathrm{c}}$ & 33605 & $-0.8 \%$ & \multicolumn{2}{|c|}{33321} & $-15.5 \%$ & 28153 \\
\hline Teaching staff (number of posts) ${ }^{c, d}$ & 26537 & $0.6 \%$ & & & $-12.1 \%$ & 23469 \\
\hline Total school staff (persons, main job) & NA & NA & & & $-14.4 \%$ & 24091 \\
\hline Teaching staff (persons, main job) & NA & NA & & & $-10.7 \%$ & 20228 \\
\hline Workloads: total/teaching & 1.37 & $0.0^{\circ}$ & & & $-5.3 \%$ & 1.30 \\
\hline Teaching workloads per teacher post & 1.24 & $0.8 \%$ & & & $-14.5 \%$ & 1.07 \\
\hline Total workloads per school staff post & 1.34 & $2.2^{\circ}$ & & & $-15.8 \%$ & 1.16 \\
\hline Students/teaching staff (gross S/T) & 9.9 & -6.1 & & & $9.4 \%$ & 10.2 \\
\hline Students/teaching workloads ${ }^{\mathrm{e}}$ & 8.0 & $-6.8^{c}$ & & & $27.9 \%$ & 9.5 \\
\hline Average class size ${ }^{\mathrm{f}}$ & 19.0 & $-2.8 \mathrm{c}$ & & & $4.2 \%$ & 19.3 \\
\hline & & Without & private, sI & cial, and & I board scho & ools \\
\hline & Annual s & chool cen & us data & & Payroll da & \\
\hline & $\begin{array}{l}\text { Sept, } \\
2008\end{array}$ & $\begin{array}{c}\% \\
\text { Change }\end{array}$ & $\begin{array}{l}\text { Sept., } \\
2009\end{array}$ & $\begin{array}{l}\text { Sept., } \\
2009\end{array}$ & $\begin{array}{c}\% \\
\text { Change }\end{array}$ & $\begin{array}{c}\text { April, } \\
2010\end{array}$ \\
\hline Students & 234931 & $-3.9 \%$ & 225706 & 220872 & - & 220872 \\
\hline Schools & 870 & $-12.6 \%$ & 760 & 739 & - & 739 \\
\hline Total workloads & 39685 & $-30.2 \%$ & 27687 & 27631 & $12.7 \%$ & 31150 \\
\hline Teaching workloads & 30074 & $-25.9 \%$ & 22280 & 22412 & $11.6 \%$ & 25012 \\
\hline Share of non-teaching workloads & $24.2 \%$ & $-19.4 \%$ & $19.5 \%$ & $18.9 \%$ & $4.3 \%$ & $19.7 \%$ \\
\hline Total school staff (number of posts) ${ }^{\mathrm{c}}$ & 28926 & $-16.5 \%$ & 24153 & 22645 & $3.8 \%$ & 23496 \\
\hline Teaching staff (number of posts) ${ }^{c, d}$ & 23643 & $-12.9 \%$ & 20603 & 20235 & $3.1 \%$ & 20859 \\
\hline Total school staff (persons, main job) & 24404 & $-15.1 \%$ & 20714 & 20697 & $2.6 \%$ & 21238 \\
\hline Teaching staff (persons, main job) & 20045 & $-11.2 \%$ & 17798 & 18565 & $2.1 \%$ & 18954 \\
\hline Workloads: total/teaching & 1.32 & $-5.8 \%$ & 1.24 & 1.23 & $1.0 \%$ & 1.25 \\
\hline Teaching workloads per teacher post & 1.27 & $-15.0 \%$ & 1.08 & 1.11 & $8.3 \%$ & 1.20 \\
\hline Total workloads per school staff post & 1.37 & $-16.4 \%$ & 1.15 & 1.22 & $8.7 \%$ & 1.33 \\
\hline Students/teaching staff (gross S/T) & 9.9 & $10.2 \%$ & 11.0 & 10.9 & $-3.0 \%$ & 10.6 \\
\hline Students/teaching workloads ${ }^{\mathrm{e}}$ & 7.8 & $29.7 \%$ & 10.1 & 9.9 & $-10.4 \%$ & 8.8 \\
\hline Average class size ${ }^{\mathrm{f}}$ & 18.8 & $4.7 \%$ & 19.6 & & & \\
\hline
\end{tabular}

Notes: ${ }^{\text {a }}$ Number of students is slightly smaller than in official statistics because it excludes students of 10 vocational schools studying according to the general education school program. ${ }^{b}$ Class sets refer to either single classes or merged classes (maybe from different grades) simultaneously instructed by one teacher. Calculation of classes and class sets includes also groups of distant students. ${ }^{\circ}$ Each staff member counts once in every school he/she works at. ${ }^{\mathbf{d}}$ As in MoES statistics, here teaching staff refers to all staff members performing some teaching in grades 1-12, even if this is not their main function in the school. ${ }^{e}$ This ratio is slightly lower than net S/T calculated according to OECD and Eurostat methodology (see Figure 4) which includes only staff members whose main task function is teaching. ${ }^{\mathrm{f}}$ According to OECD and Eurostat methodology, calculation of class size excludes special schools and classes. Sources: Calculation with annual School Census data and school payroll data provided by MoES (21 schools are missing from the payroll data for September). 
Table 3 - Differentiation of classroom teachers' base salary, Spring 2010.

Results of local authorities' survey, schools heads survey, and payroll data compared

School directors' survey

(577 municipal schools):

proportion of schools where base

salary (wage per workload) is "the

same for all classroom teachers

except school management" a
School payroll data

(820 municipal schools)

Wage per workload is the

same for all classroom

teachers except school

management (or varies within a $10 \mathrm{LVL}$ range) ${ }^{\mathrm{a}}$

\begin{tabular}{|c|c|c|c|c|c|c|c|c|}
\hline \multirow{3}{*}{$\begin{array}{l}\text { Because of } \\
\text { recommendation } \\
\text { of local education } \\
\text { authority }\end{array}$} & \multirow{3}{*}{$\begin{array}{l}\text { For } \\
\text { other } \\
\text { reasons }\end{array}$} & & \multirow[b]{3}{*}{$\begin{array}{l}\% \text { of } \\
\text { schools }\end{array}$} & \multirow{2}{*}{\multicolumn{2}{|c|}{$\begin{array}{l}\% \text { of counties } \\
\text { where at least } 3 / 4 \text { of } \\
\text { schools } b \\
\text { have wage per load }\end{array}$}} & \multirow{2}{*}{\multicolumn{2}{|c|}{$\begin{array}{l}\text { Provide some rules or } \\
\text { recommendations }\end{array}$}} & \multirow{3}{*}{$\begin{array}{l}\text { Do not } \\
\text { provide any } \\
\text { guidance } \\
\text { on base } \\
\text { salary } \\
\text { differentiation }\end{array}$} \\
\hline & & \multirow[b]{2}{*}{ Total } & & & & & & \\
\hline & & & & $\begin{array}{l}\text { Within } \\
\text { a } \\
10 \mathrm{LVL} \\
\text { range }\end{array}$ & $\begin{array}{l}\text { Varying } \\
\text { in a } \\
\text { range } \\
\text { wider } \\
\text { than } \\
10 \mathrm{LVL} \\
\end{array}$ & $\begin{array}{l}\text { which do not } \\
\text { encourage } \\
\text { base salary } \\
\text { differentiation }\end{array}$ & $\begin{array}{l}\text { which include } \\
\text { criteria for } \\
\text { base salary } \\
\text { differentiation }\end{array}$ & \\
\hline $26.2 \%$ & $31.9 \%$ & $58.1 \%$ & $63.4 \%$ & $60.6 \%$ & $7.3 \%$ & $28.2 \%$ & $17.6 \%$ & $54.1 \%$ \\
\hline
\end{tabular}

Notes: ${ }^{\text {a }}$ Base salary variation within a $10 \mathrm{LVL}$ range can be considered as no variation, because the minimum rates mentioned in the Cabinet regulation vary between 245 and 255 LVL depending on teacher experience (see Table 1). ${ }^{\mathrm{b}}$ When calculating these proportions, 9 counties with just one school are excluded.

Source: Calculation with survey data and school payroll data.

Table 4 - School level determinants of the share of municipal funding $(y)$ in teachers' compensation, April 2010

Riga

$(\mathrm{E}[y]=0.129 ;$

$\mathrm{E}[y \mid y>0]=0.129)$

$$
\mathrm{d} y / \mathrm{d} x^{\mathrm{a}} \quad \text { S.e. }{ }^{\mathrm{b}}
$$

Log (school size)

$$
-0.023 * * * \quad 0.008
$$

Preschool students)

(School students)

Share of students

instructed in minority

languages

Rural school

County fixed effects

N obs.

Of which with $y=0$

$0.780 * * *$

0.131
Other republ. cities

$$
\mathrm{E}[y]=0.017)
$$

$\mathrm{E}[y \mid y>0]=0.022$

$$
\mathrm{d} y / \mathrm{d} x^{\mathrm{a}} \quad \text { S.e. }{ }^{\mathrm{c}}
$$

$-0.001$

0.003

$0.115^{* * *}$

0.041

0.000

0.001

0.002

0.007

0.008

0.004
Other cities and rural ${ }^{d}$

$(\mathrm{E}[y]=0.041)$

$\mathrm{E}[y \mid y>0]=0.074)$

$\mathrm{d} y / \mathrm{d} x^{\mathrm{a}} \quad$ S.e. ${ }^{\mathrm{c}}$

$-0.007 * * \quad 0.003$

$0.128 * * * \quad 0.014$

Notes: ${ }^{a}$ Marginal effects (change in $y$ caused by a unit change in $\mathrm{x}$ ) estimated from tobit models.

${ }^{\mathrm{b}}$ Robust standard errors. ${ }^{\mathrm{c}}$ Robust standard errors adjusted for correlation within city or county (novads)

d 20 schools

with very high proportions of pre-school students excluded. $* *, * * *$ - estimates significantly different from 0 at 5\% (resp. 1\%) level. Source: Calculation with payroll data provided by MoES. 


\section{Table 5 - Municipal level determinants of the proportion of state subsidy transferred to school wage bills, April 2010}

Proportion

Dependent variable of the baseline wage bill
Proportion

of the extended wage bill
Proportion of the full (actual) subsidy

\section{Characteristics of the local school system}

Coef. S. E. Coef.

S. E.

Coef.

S. E. Coef.

S. E.

Gross student/teacher ratio

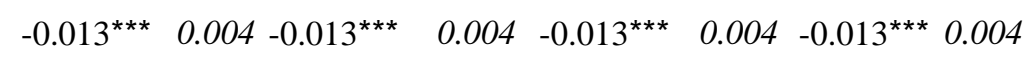

Share of students in:

$$
\begin{aligned}
& \text { grades } 1 \text { to } 4 \text { (day programs) }{ }^{\text {a }} 0.038 \\
& \text { grades } 10 \text { to } 12 \text { (day programs) }{ }^{\mathrm{b}} 0.201 \\
& \text { evening programs }{ }^{\mathrm{c}}-0.127 \\
& \text { distant programs }{ }^{\mathrm{c}}-0.102
\end{aligned}
$$

$0.193-0.030$

$0.197-0.022$

$0.194-0.051$

0.187

$0.166 \quad 0.160$

$0.163 \quad 0.143$

$0.170 \quad 0.138$

0.157

$0.170-0.396$

$0.300-0.092$

$0.177-0.379$

0.296

$0.164-0.274$

$0.217-0.320$

$0.237-0.303$

0.201

licensed special needs programs ${ }^{\mathrm{d}}-1.770^{\star *}$

$0.717-2.247^{\star \star \star}$

$0.679-1.842^{\text {** }}$

$0.743-2.264^{\star \star \star} 0.639$

other claimed special programs ${ }^{\mathrm{e}} 0.724^{\star \star \star}$

$0.2350 .684^{\star \star \star}$

programs with in-depth study of specific subjects ${ }^{\mathrm{f}} 0.294^{\star \star}$

0.1140 .151

$0.215 \quad 0.078$

0.2110 .055

0.201

Some schools are rural

-0.049 ** $0.019-0.048^{\star \star}$

$0.095 \quad 0.092$

$0.092 \quad 0.150^{\star} \quad 0.089$

Municipality in debt to state budget

$0.019-0.048^{\star *}$

$0.019-0.040^{* *}$

$0.019-0.051^{* * *} 0.018$

Constant

$1.082^{\star \star \star} 0.1121 .115^{\star \star \star}$

$0.018-0.078^{\star \star \star}$

$0.025-0.093^{\star * *} 0.017$

R-squared

0.3405

0.3528

0.112

$1.101^{\star \star \star}$

0.11

Root MSE

0.0634

0.0666

0.2774

0.0631

$1.128^{\star \star \star} 0.107$

$\mathrm{N}$ observations

118

118

111

0.0617

118

Method

Linear regression with robust S.E.'s

Interval

Notes: Private, special and board schools are financed separately and not considered in this table. State subsidy here refers to the budget transfers for teacher compensation in municipal schools of general education. It excludes the subsidy for the mandatory schooling of 5-6 years olds, as well as for interest groups education. According to local governments' officials, they keep part of the subsidy as an 'emergency fund'. One purpose of such a fund is to provide compensation to teachers who substitute absent colleagues (for instance, those on a sick leave); such compensation, which might account to $2-3 \%$ of the annual wage bill, is for technical reasons not reflected in the payroll files. However, in some municipalities the 'emergency fund' is substantially larger than seems necessary for substitution purposes.

a, b, c, These students enter the financing formula with coefficients $0.75,1.25,0.82$, respectively (unless enrolled in special or in-depth programs, see ${ }^{\mathrm{d}, \mathrm{e}, \mathrm{f}}$ ).

${ }^{\mathrm{d}}$ Number of students in special programs according to MoES statistics. Coefficient 1.47 applies.

e Number of claimed students in special programs in excess of that in MoES statistics. All claims by the local governments have been accepted. Coefficient 1.47 applies to this category, but this is not accounted for in the baseline wage bill, as well as in the extended wage bill due to data limitations. Thus total state-funded compensation found in payroll data can exceed the extended wage bill.

$\mathrm{f}$ The concept of 'professionally oriented programs with in-depth study of some subject [in addition to standard program in other subjects]' emerged immediately before the reform without a strict definition; nevertheless the financing scheme applies coefficient 1.31 to students of such programs. In fact, all claims by local governments for running such programs have been accepted. This category is not accounted for in the baseline wage bill, but it is accounted for in the extended wage bill.

${ }^{g}$ For 7 counties with unlisted special programs, for which some schools were missing in April payroll files, upper and lower estimates of the actual subsidy to non-missing schools have been used.

Source: Calculation with administrative data and school payroll data. 


\section{Table 6 - School level determinants of the proportion of state subsidy transferred to school wage bills, April 2010}

A. Proportion of the baseline wage bill

Schools in urban Schools in mixed

All schools municipalities urban-rural Schools in rural municipalities municipalities

School characteristics Coef. $\quad$ S. E. Coef. S. E. Coef. S. E. Coef. S. E.

School size (log)

$-0.133^{\star \star \star} \quad 0.016-0.103^{\star \star \star} \quad 0.032-0.213^{\star \star \star} \quad 0.026-0.043^{\star} \quad 0.031$

Share of students in:

$\begin{array}{lllllll}\text { grades } 1 \text { to } 4 \text { (day programs) }{ }^{\mathrm{a}}-0.013 & 0.080-0.113 & 0.181 & 0.018 & 0.105 & -0.136 & 0.141\end{array}$

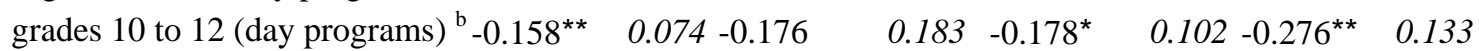

evening programs ${ }^{\mathrm{c}}-0.032 \quad 0.073-0.051 \quad 0.139-0.077 \quad 0.135-1.185 \quad 2.829$

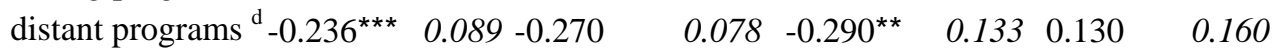

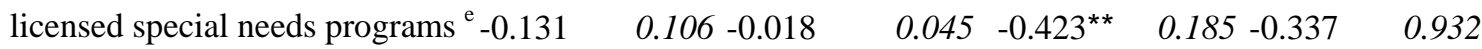

programs with in-depth study of

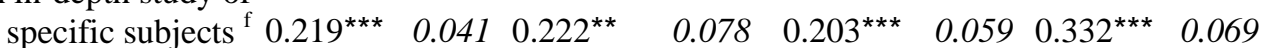

$\begin{array}{lllllll}\text { Mixed Latvian-Russian school } & 0.005 & 0.022-0.008 & 0.024 & 0.004 & 0.038-0.027 & 0.029\end{array}$

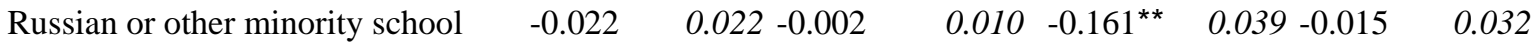

Rural school

$0.080^{\star * *} \quad 0.024 \quad-0.030 \quad 0.032$

Constant

Municipality fixed effects

R-squared

$1.850^{\star \star \star} 0.1131 .688^{\star \star \star}$

$0.292 \quad 2.344^{\star * *} \quad 0.190 \quad 1.560^{\star \star *} 0.150$

yes yes yes yes

$\begin{array}{llll}0.6457 & 0.4167 & 0.7163 & 0.5826\end{array}$

$\begin{array}{lllll}\text { Root MSE } & 0.1372 & 0.1107 & 0.1451 & 0.1187\end{array}$

$\begin{array}{lllll}\text { N observations } & 739 & 210 & 374 & 155\end{array}$

B. Proportion of the extended wage bill

Share of students in:

programs with in-depth study of

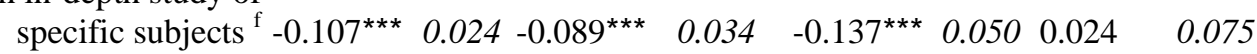

Other variables

Coefficients similar to those in panel A

Method

Linear regression with robust standard errors adjusted for clustering on municipality

Notes: ${ }^{\mathrm{a}, \mathrm{b}, \mathrm{c}, \mathrm{d}}$ These students enter the financing formula with coefficients $0.75,1.25,0.82,0.82$ respectively (unless enrolled in special or in-depth programs, see ${ }^{\mathrm{e}, \mathrm{f}}$ ).

${ }^{\mathrm{e}}$ Number of students in special programs according to MoES statistics. Coefficient 1.47 applies.

${ }^{\mathrm{f}}$ The concept of 'professionally oriented programs with in-depth study of some subject' (coefficient 1.31 applies) emerged immediately before the reform without a strict definition. In fact, all claims by local governments for running such programs have been accepted. This category is not accounted for in the baseline wage bill, but it is accounted for in the extended wage bill.

Source: Calculation with administrative data and school payroll data. 
Table 7 Classroom teachers by school and personal characteristics, April 2010

(descriptive statistics of key explanatory variables in Tables 8-9)

Percentiles based on teacher posts, i.e. 'at the given school'

Applicable for Table 9

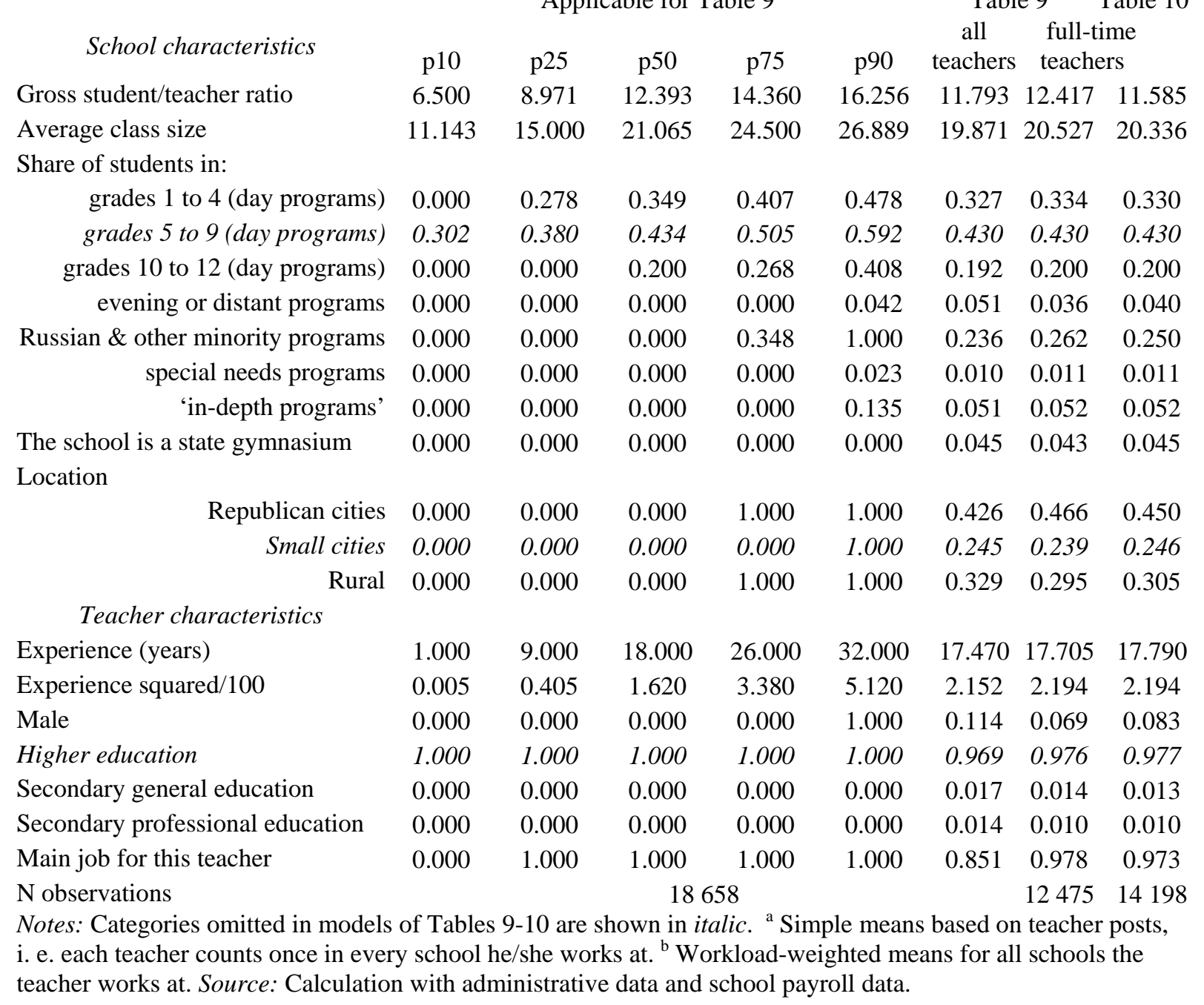




\section{Table 8 - Determinants of classroom teacher earnings in the given school, April 2010}

Log gross earnings per:

workload

Mixed linear models

Tasks compensated

Source of financing

School characteristics

[1] $[2 \mathrm{a}]$
teaching
state

No evening schools

$0.006^{\star \star *} \quad 0.006^{\star \star \star}$

$0.009^{\star \star \star} \quad 0.009^{\star \star \star}$ contact hour

workload

month $^{\mathrm{a}}$

[2b] [3]

teaching state

$\begin{array}{cc}\text { [4] } & {[5]} \\ \text { all } & \text { all } \\ \text { state } & \text { all }\end{array}$

[6]

all

all

Gross student/teacher ratio

Average class size

Evening school included

Share of students in:

grades 10 to 12 (day programs) $0.050^{*}$

evening or distant programs $0.088^{*}$

Russian \& other minority programs -0.012

special needs programs $0.148^{\star \star}$

'in-depth programs' $0.060^{\star \star \star}$

$\begin{array}{llllll}-0.012 & -0.014 & 0.022 & -0.043 & -0.074^{\star \star} & -0.059 \\ 0.050^{\star} & 0.055^{\star} & 0.130^{\star \star} & 0.023 & 0.019 & 0.163^{\star \star \star} \\ 0.086^{\star} & 0.065^{\star \star \star} & 0.182^{\star \star \star} & 0.044^{\star} & 0.026 & 0.017 \\ -0.013 & -0.012 & -0.038^{\star} & -0.006 & -0.003 & -0.072^{\star \star \star} \\ 0.147^{\star \star} & 0.131^{\star \star} & 0.185^{*} & 0.088 & 0.044 & 0.179^{\star \star} \\ 0.060^{\star \star \star} & 0.065^{\star \star \star} & 0.070^{\star} & 0.053^{\star \star} & 0.057^{\star \star \star} & 0.103^{\star \star \star} \\ 0.071^{\star \star \star} & 0.071^{\star \star \star} & 0.052 & 0.083^{\star \star \star} & 0.067^{\star \star \star} & 0.078^{\star \star \star} \\ & & & & & \\ -0.056^{\star \star \star} & -0.049^{\star \star} & -0.077^{\star \star} & -0.025 & -0.035 & -0.092^{\star \star \star} \\ -0.006 & -0.005 & -0.042^{\star \star} & -0.012 & -0.010 & -0.026^{\star}\end{array}$

Teacher characteristics

Experience (years)

$0.002^{\star \star \star} \quad 0.002^{\star \star \star} \quad 0.002^{\star \star \star} \quad 0.004^{\star \star \star}$

$0.002^{\star \star \star} \quad 0.002^{\star \star \star} \quad 0.008^{\star \star \star}$

Experience squared/100

$-0.007^{\star \star \star}-0.007^{\star \star \star}-0.007^{\star \star \star}-0.021^{\star \star \star}$

$-0.006^{\star \star \star}-0.006^{\star \star \star}-0.036^{\star \star \star}$

Male

$\begin{array}{llll}-0.003 & -0.002 & -0.003 & -0.046^{* * *}\end{array}$

$0.011^{\star \star \star} 0.018^{\star \star}-0.020^{\star \star}$

Education (vs. Higher)

Secondary general $-0.023^{\star \star \star} \quad-0.023^{\star \star \star} \quad-0.024^{\star \star \star}-0.007$

$\begin{array}{lll}-0.019^{\star \star} & -0.014 & -0.081^{\star \star *}\end{array}$

Secondary professional $-0.011^{\star *} \quad-0.012^{\star \star} \quad-0.013^{\star \star} \quad-0.013$

Main job for this teacher

$0.004^{\star \star \star} \quad 0.003^{\star} \quad 0.005^{\star \star} \quad 0.067^{\star \star \star}$

$\begin{array}{lll}-0.006 & -0.009 & -0.088^{\star * *}\end{array}$

Main subject taught dummies (16)

County random effects - std. dev.

$\begin{array}{cccc}\text { no } & \text { yes } & \text { yes } & \text { yes } \\ 0.045^{\star * \star} & 0.045^{\star \star \star} & 0.046^{\star * \star} & 0.074^{\star \star *}\end{array}$

$-0.036^{\star \star \star}-0.049^{\star \star \star}$

$0.120^{\star \star \star}$

yes yes yes

School random effects - std. dev.

$0.080^{\star \star *} \quad 0.080^{\star \star \star} \quad 0.081^{\star \star \star} \quad 0.153^{\star \star \star}$

$0.047^{\star \star \star} \quad 0.052^{\star \star \star} \quad 0.075^{\star \star \star}$

Residual std. deviation

$0.074^{\star \star \star} \quad 0.074^{\star \star \star} \quad 0.075^{\star \star \star} \quad 0.161^{\star \star \star}$

$0.079^{\star \star \star} 0.083^{\star \star \star}$

$0.097^{\star * \star}$

LR test vs. lin. regression, chi2(2)

$\begin{array}{llll}14493.7 & 14507.8 & 15225.4 & 9908.28\end{array}$

$0.141^{\star \star \star} 0.157^{\star \star \star}$

$0.214^{\star \star \star}$

Coefficients on gross $\mathrm{S} / \mathrm{T}$ and elasticities with respect to gross $\mathrm{S} / \mathrm{T}$ in two similar models without class size control

Gross student/teacher ratio

$\begin{array}{ccccccc}0.013^{\star \star \star} & 0.013^{\star \star \star} & 0.013^{\star \star \star} & 0.020^{\star \star \star} & 0.014^{\star \star \star} & 0.017^{\star \star \star} & 0.039^{\star \star \star} \\ 0.136^{\star \star \star} & 0.136^{\star \star \star} & 0.137^{\star \star \star} & 0.228^{\star \star \star} & 0.138^{\star \star \star} & 0.162^{\star \star \star} & 0.385^{\star \star \star} \\ 17892 & 17892 & 18658 & 18596 & 18603 & 18658 & 12475\end{array}$

Log (gross student/teacher ratio)

$17892 \quad 17892 \quad 18658 \quad 18596$

860318658

12475

Notes: Special, board and private schools excluded. Teachers, whose main job in the school is not teaching, excluded. ${ }^{a}$ Model [6] excludes teachers which have less than 1 full workload in the given school or work in more than 1 school. ${ }^{* \star *},{ }^{* \star},{ }^{*}, *$ - estimates significantly different from 0 at $1 \%, 5 \%, 10 \%, 13 \%$ level.

Source: Calculation with school payroll data. 
Table 9 - Determinants of full-time teacher earnings in all schools/jobs, April 2010 Log gross earnings

Classroom teachers

Mixed linear models

Tasks compensated

Source of financing

School characteristics ${ }^{\text {a }}$

Gross student/teacher ratio

Average class size

[1]

[2]

[3]

teaching teaching state

state

all

$0.022^{\star \star \star}$

$0.023^{\star \star \star} 0.021^{\star \star \star}$

$0.008^{\star \star \star}$

Share of students in:

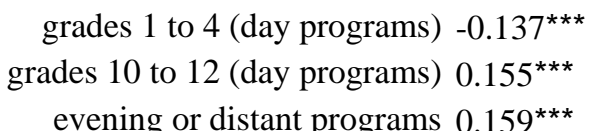

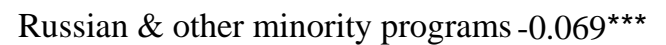

special needs programs $0.176^{\star \star}$

'in-depth programs' $0.083^{\star \star \star}$

The school is a state gymnasium

$0.061^{\star \star}$

Location (vs. small cities)

$$
\begin{array}{r}
\text { Republican cities }-0.116^{\star \star \star} \\
\text { Rural }-0.051^{\star \star \star}
\end{array}
$$

Teacher characteristics

Experience (years)

Experience squared/100

$$
0.009^{\star \star *}
$$$$
-0.038^{\star \star *}
$$

$0.008^{\star \star \star}$

$0.006^{\star \star \star}$

\section{$0.024^{\star \star \star}$}

$0.005^{\star * *}$

[4]

[5]

all

all

state all

Male

$$
-0.061^{\star \star \star}
$$

$\begin{array}{ll}-0.052 & 0.020 \\ 0.164^{\star \star \star} & 0.251^{\star \star \star} \\ 0.151^{\star \star \star} & 0.208^{\star \star \star}\end{array}$

$-0.079^{*}$

0.033

$0.151^{\star \star \star} 0.208^{\star \star \star}$

$0.196^{\star \star \star}$

$0.185^{\star \star \star}$

$-0.085^{\star * *}-0.085^{\star * *}$

$0.137^{\star \star \star}$

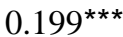

$0.194^{\star \star} 0.225^{\star \star *}$

$-0.054^{\star \star *}$

$0.150^{*}$

$-0.079 * \star \star$

$0.081^{\star * \star} 0.089^{\star \star *}$

$0.101^{\star \star *}$

$0.248^{\star \star \star}$

$0.054^{\star \star} 0.048^{*}$

0.039

$0.071^{\star \star *}$

$0.048^{\star *}$

Education (vs. Higher)

Secondary general $-0.081^{\star \star \star}$

Secondary professional $-0.103^{\star \star \star}-0.076^{\star \star \star}-0.087^{\star \star \star}$

One of the schools is teacher's main job

$0.131^{\star \star *}$

$0.114^{\star \star \star} 0.131^{\star \star \star}$

$-0.163^{\star \star \star}-0.125^{\star \star \star}$

$0.135^{\star \star \star}-0.168^{\star \star \star}$

$-0.056^{\star \star \star}$

$-0.050^{\star \star \star}$

Main job (vs. teaching grades 1-9)

Teaching grades 10-12

Main subject taught dummies (16)

County random effects - std. deviation ${ }^{\mathrm{b}}$

School random effects - std. deviation ${ }^{\mathrm{b}}$

Residual std. deviation

Degrees of freedom $(k)$

Wald chi2( $k)$

$\mathrm{N}$ observations

\section{Director}

Deputy Director Support staff ${ }^{\mathrm{c}}$

Pre-school

Interest groups

$\begin{array}{ccccc} & & & 0.054^{\star \star \star} & 0.053^{\star \star \star} \\ & & & 0.401^{\star \star \star} & 0.398^{\star \star \star} \\ & & & 0.246^{\star \star \star} & 0.243^{\star \star \star} \\ & & & -0.632^{\star \star \star} & -0.206^{\star \star \star} \\ & & & -0.600^{\star \star \star} & -0.275^{\star \star \star} \\ & & & -0.894^{\star \star \star} & -0.174^{\star \star \star} \\ \text { no } & \text { yes } & \text { yes } & \text { no } & \text { no } \\ 0.070^{\star \star \star} & 0.075^{\star \star \star} & 0.092^{\star \star \star} & 0.087^{\star \star \star} & 0.082^{\star \star \star} \\ 0.088^{\star \star \star} & 0.090^{\star \star \star} & 0.098^{\star \star \star} & 0.093^{\star \star \star} & 0.086^{\star \star \star} \\ 0.238^{\star \star \star} & 0.222^{\star \star \star} & 0.203^{\star \star \star} & 0.264^{\star \star \star} & 0.193^{\star \star \star} \\ 17 & 33 & 33 & 24 & 24 \\ 1605.61 & 3646.77 & 2812.55 & 11312.4 & 7712.8 \\ 14198 & 14198 & 14198 & 16860 & 16860\end{array}$

Notes: Special, board and private schools excluded.

Teachers with less than 1 full workload (in all schools) excluded. ${ }^{a}$ Average for all schools the teacher works at, weighted by workload. ${ }^{b}$ Models without random effects are rejected by LR test in all specifications. ${ }^{\mathrm{c}}$ Librarians, psychologists, social educators, etc. ***, **, *, * - estimates significantly different from 0 at $1 \%$, 5\%, 10\% level, respectively. Source: Calculation with school payroll data. 


\section{Table 10 - Net student/teacher ratio effect on teacher earnings per workload}

before and after the reform

\begin{tabular}{|c|c|c|c|c|c|c|}
\hline Dependent: & [1a] & [1b] & [2a] & {$[2 \mathrm{~b}]$} & [3a] & [3b] \\
\hline $\begin{array}{l}\text { Log earnings per workload } \\
\text { [1a], [2a], [3a] - all tasks } \\
\text { included; }\end{array}$ & \multicolumn{2}{|c|}{$\begin{array}{l}\text { Jan/2008- } \\
\text { Aug/2009 }\end{array}$} & \multicolumn{2}{|c|}{$\begin{array}{l}\text { Sep/2009- } \\
\text { Dec/2009 }\end{array}$} & \multicolumn{2}{|c|}{$\begin{array}{c}\text { Jan/2010- } \\
\text { Aug/2010 }\end{array}$} \\
\hline $\begin{array}{l}\text { 1b], [2b], [3b] - teaching-related } \\
\text { asks, only classroom teachers }\end{array}$ & \multicolumn{2}{|c|}{$\begin{array}{l}\text { Coef. } \times 100 \\
(\text { S.e. } \times 100)\end{array}$} & \multirow{2}{*}{\multicolumn{2}{|c|}{$\begin{array}{l}\text { Coef. } \times 100 \\
(\text { S.e. } \times 100) \\
\text { Model A }\end{array}$}} & \multicolumn{2}{|c|}{$\begin{array}{l}\text { Coef. } \times 100 \\
(\text { S.e. } \times 100)\end{array}$} \\
\hline & & & & & & \\
\hline $\begin{array}{l}\text { Students per teaching workload }{ }^{\mathrm{a}} \\
\text { - 'old' municipality }{ }^{\mathrm{b}} \text { average }\end{array}$ & $\begin{array}{l}-4.96^{\star \star \star} \\
(1.84)\end{array}$ & $\begin{array}{l}-4.60^{\star \star \star} \\
(1.83)\end{array}$ & $\begin{array}{r}-0.91^{\star *} \\
(0.42)\end{array}$ & $\begin{array}{l}-0.80^{*} \\
(0.44)\end{array}$ & $\begin{array}{l}1.65^{\star *} \\
(0.76)\end{array}$ & $\begin{array}{l}1.09 \\
(0.69)\end{array}$ \\
\hline $\begin{array}{l}\text { Students per teaching workload }{ }^{\mathrm{c}} \\
\text { - 'old' municipality }{ }^{\mathrm{b}} \text { average }\end{array}$ & NA & NA & $\begin{array}{r}\text { Mod } \\
-0.65^{*} \\
(0.38)\end{array}$ & $\begin{array}{l}\text { B } \\
-0.67^{*} \\
(0.38)\end{array}$ & $\begin{array}{r}2.39 \star \star \star \\
(0.80)\end{array}$ & $\begin{array}{r}1.90^{\star \star \star} \\
(0.71)\end{array}$ \\
\hline \multirow[t]{2}{*}{$\begin{array}{l}\text { Students per teaching workload }{ }^{\mathrm{c}} \\
\text { - 'new' municipality }{ }^{\mathrm{a}} \text { average }\end{array}$} & NA & NA & $\begin{array}{l}\text { Mod } \\
0.35 \\
(0.43)\end{array}$ & $\begin{array}{r}\text { C } \\
0.26 \\
(0.43)\end{array}$ & $\begin{array}{r}5.02^{\star \star \star} \\
(0.59)\end{array}$ & $\begin{array}{r}4.24^{\star \star \star} \\
(0.54)\end{array}$ \\
\hline & \multicolumn{6}{|c|}{ Model D } \\
\hline \multirow[t]{2}{*}{$\begin{array}{l}\text { Students per teaching workload }{ }^{\mathrm{c}} \\
\text { in the school }\end{array}$} & NA & NA & $\begin{array}{c}0.16 \\
(0.14)\end{array}$ & $\begin{array}{c}0.00 \\
(0.13)\end{array}$ & $\begin{array}{r}2.75^{\star \star \star} \\
(0.27)\end{array}$ & $\begin{array}{r}2.80^{\star * \star} \\
(0.23)\end{array}$ \\
\hline & \multicolumn{6}{|c|}{ Model E } \\
\hline $\begin{array}{l}\text { Students per teaching workload }{ }^{\text {a }} \\
\text { in the school }\end{array}$ & NA & NA & $\begin{array}{l}0.33^{\star *} \\
(0.16)\end{array}$ & $\begin{array}{r}0.18 \\
(0.15)\end{array}$ & $\begin{array}{r}0.96^{\star \star *} \\
(0.27)\end{array}$ & $\begin{array}{r}1.05^{\star \star \star} \\
(0.23)\end{array}$ \\
\hline $\begin{array}{l}\text { Other controls } \\
\text { (specifications [1a], [1b] include } \\
\text { also quarter fixed effects) }\end{array}$ & \multicolumn{6}{|c|}{$\begin{array}{l}\text { Teacher's gender; ethnicity ([1]) or language of instruction } \\
\text { ([2], [3]); job type ( } 4 \text { categories); age, age squared and } \\
\text { tenure ([1]) or experience as a teacher and its square ([2], } \\
\text { [3]); number of teachers in the school ( } 4 \text { cat.) }\end{array}$} \\
\hline Data source & \multirow{2}{*}{\multicolumn{2}{|c|}{$\begin{array}{l}\text { LFS } \\
\text { Survey interval } \\
\text { regression }\end{array}$}} & \multicolumn{2}{|c|}{ Payroll data } & \multicolumn{2}{|c|}{ Payroll data } \\
\hline Method & & & & odel w & municip & $\begin{array}{l}\text { ality and } \\
\text { ects }\end{array}$ \\
\hline N observations & 832 & 798 & 13592 & 10820 & 14714 & 13288 \\
\hline
\end{tabular}

Notes: Only full-time teachers at the main job with completed higher education included. School heads and deputy heads are excluded. Special, board, and private schools are excluded. ${ }^{\text {a }}$ September school census data. ${ }^{\mathrm{b}}$ Local governments of the 'old' municipalities (7 largest cities and 26 rajons (districts)) had an impact on teacher earnings before September 2009. ${ }^{c}$ Current payroll data. ${ }^{d}$ Local governments of the 'new' municipalities (9 republican cities and 109 novads) have an impact on teacher earnings since September 2009. Coefficients in models D, E might be somewhat overestimated due to endogeneity of school level student/teacher ratio in the earnings models. $\quad{ }^{\star \star \star},{ }^{\star \star},{ }^{*}$ - estimates significantly different from 0 at $1 \%, 5 \%, 10 \%$ level (based on robust standard errors adjusted to clustering on municipality).

Source: Calculation with LFS data and administrative data provided by MoES. 


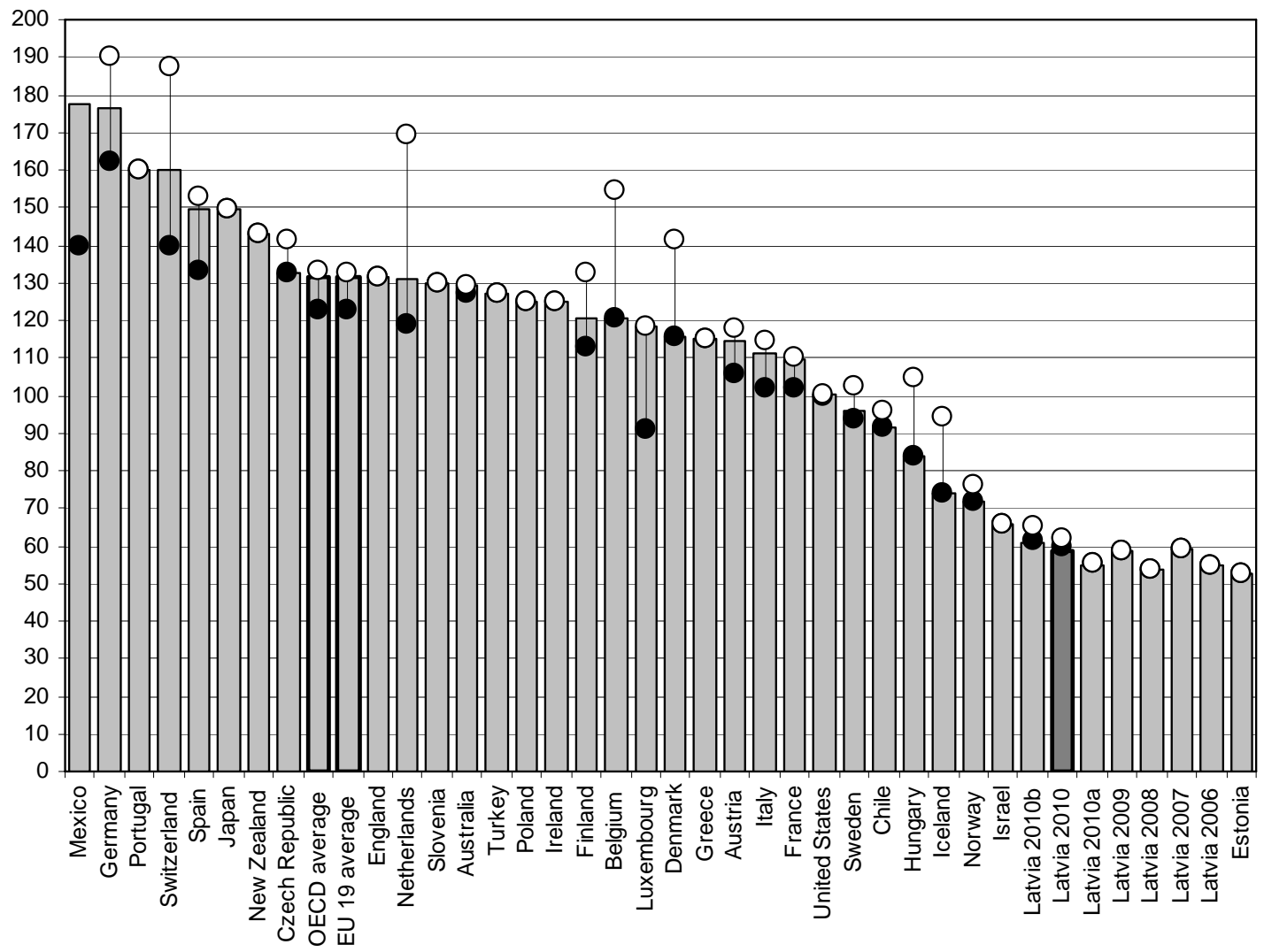

Figure 1 - Annual statutory teachers' salaries per workload in public schools as percentage of GDP per capita after 15 years of experience, by level of education.

OECD member and partner countries, 2007, and Latvia, 2006-2010.

Notes: OECD countries' data (with few exceptions) are for school year 2006/2007. Both for OECD countries and for Latvia, statutory salary in school year $t /(t+1)$ is related to GDP per capita in calendar year $t$.

Latvia 2010a: September- December 2009; Latvia 2010b: January-August 2010;

Latvia 2010: average for the school year 2009/2010.

Sources: All countries except Poland and Latvia: calculation based on OECD (2009, Tables D3.1 and X2.2), using GDP of 2006 (rather than 2007) as a base. Poland (2006): calculation based on ILO LABORSTA data; Latvia 2006-2009: calculation based on government regulations for teacher salaries. Latvia 2010: calculation based on school payroll data provided by MoES. 


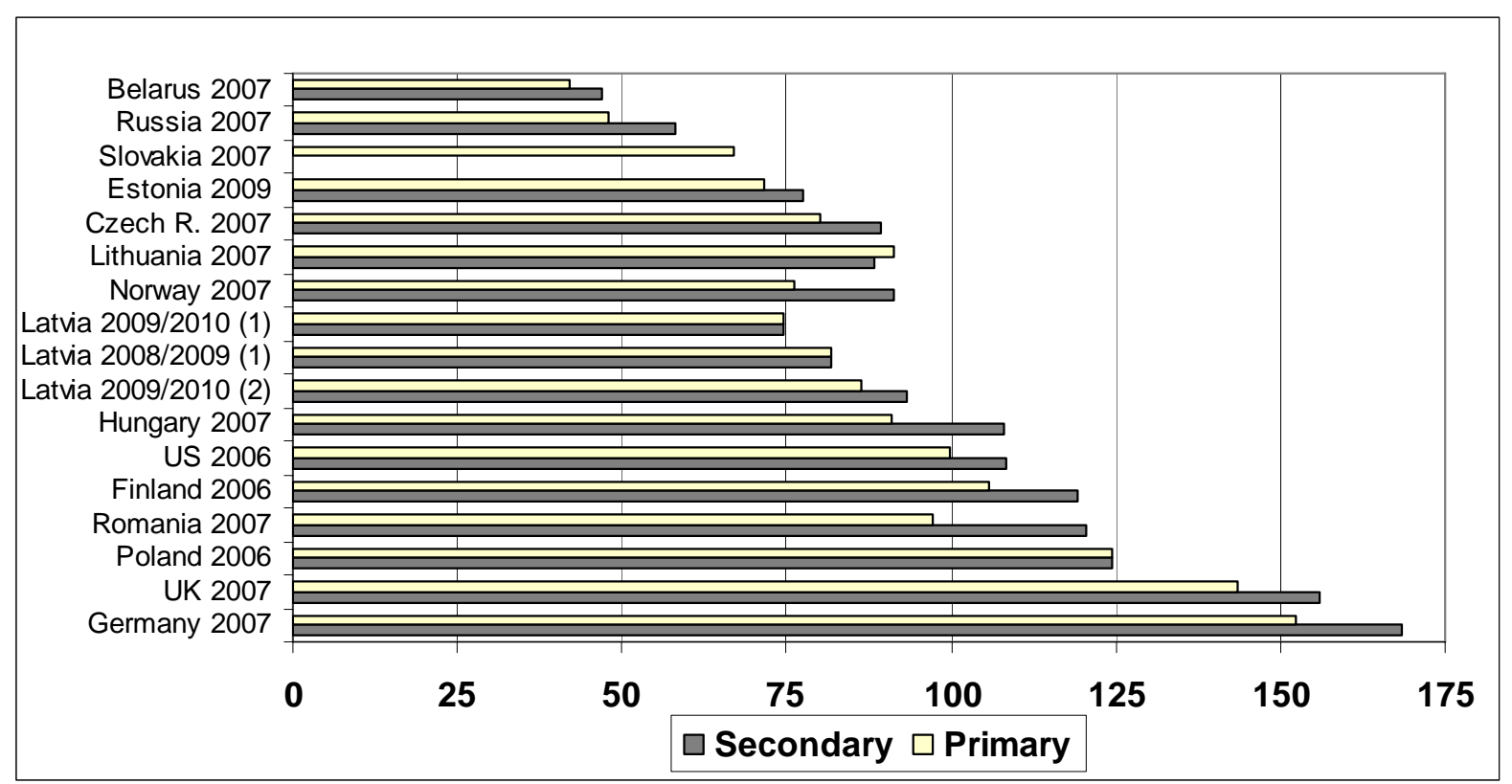

Figure 2 - Annual average gross teacher earnings in public schools (per cent of GDP per capita), by level of education.

Latvia, selected European countries, and the US.

Notes: Entries 'Latvia 2008/2009 (1)' and 'Latvia 2009/2010 (1)' refer to all teachers (including administrative and support staff, both full-time and part-time), while 'Latvia 2009/2010, (2)' and other countries' data refer only to classroom teachers with full-time workload. Source: Calculation with teacher earnings data (Latvia administrative data; Estonia - LFS data, other countries - ILO LABORSTA data), GDP (in national currency, current prices) and population data of Statistics Latvia, Statistics Estonia and UNESCO Institute of Statistics.

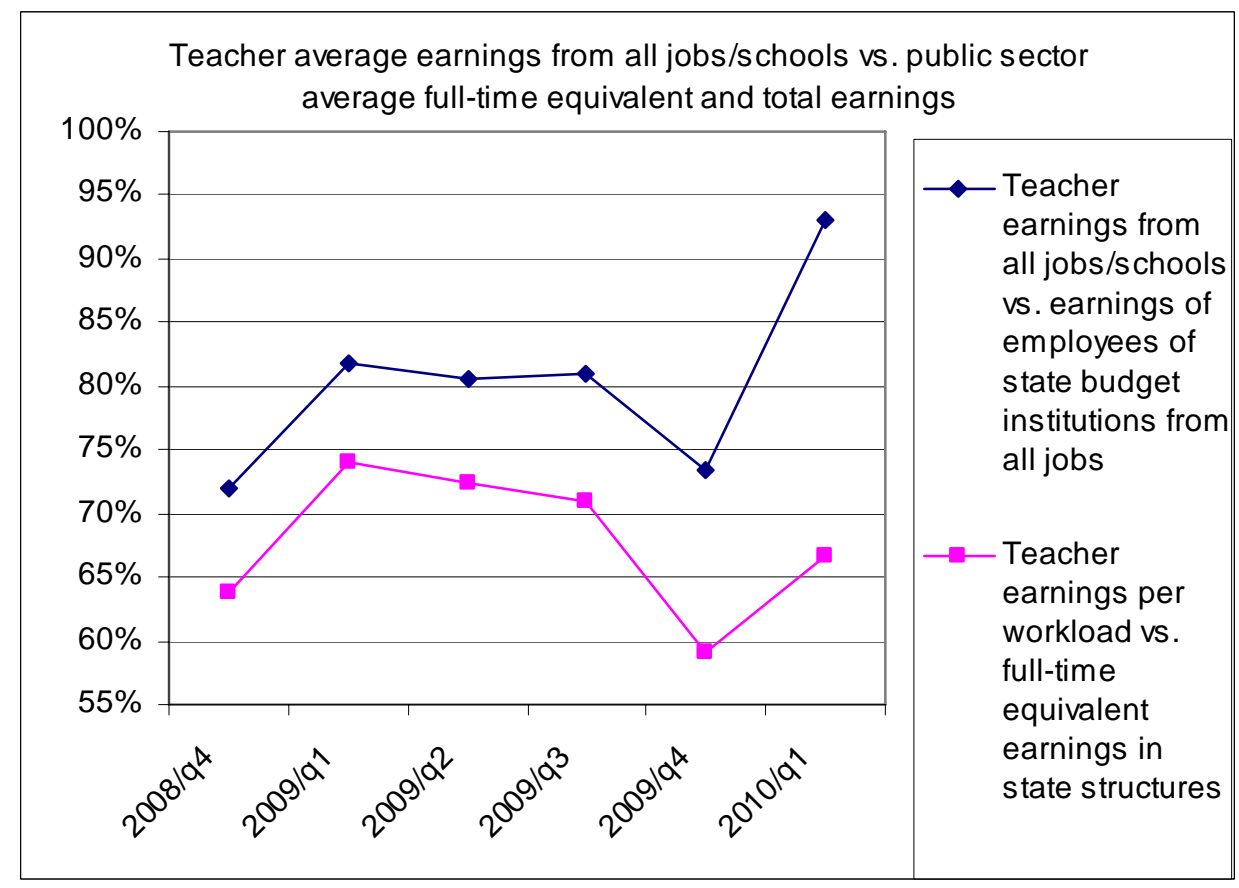

Figure 3 - Teacher average earnings per month and per workload vs. public sector average full-time equivalent earnings, 2008/Q4-2010/Q1.

Notes: Data on teacher earnings include both full-time and part-time workers. Monthly earnings are earnings per person from all jobs in all schools. All schools and all teachers, as well as administrative and qualified support staff, included. Note that teachers carry, on average, about 1.5 workloads. Sources: Public sector earnings: Statistics Latvia. Teacher earnings: Finance department of MoES (school year 2008/2009) and school payroll data (school year 2009/2010). 


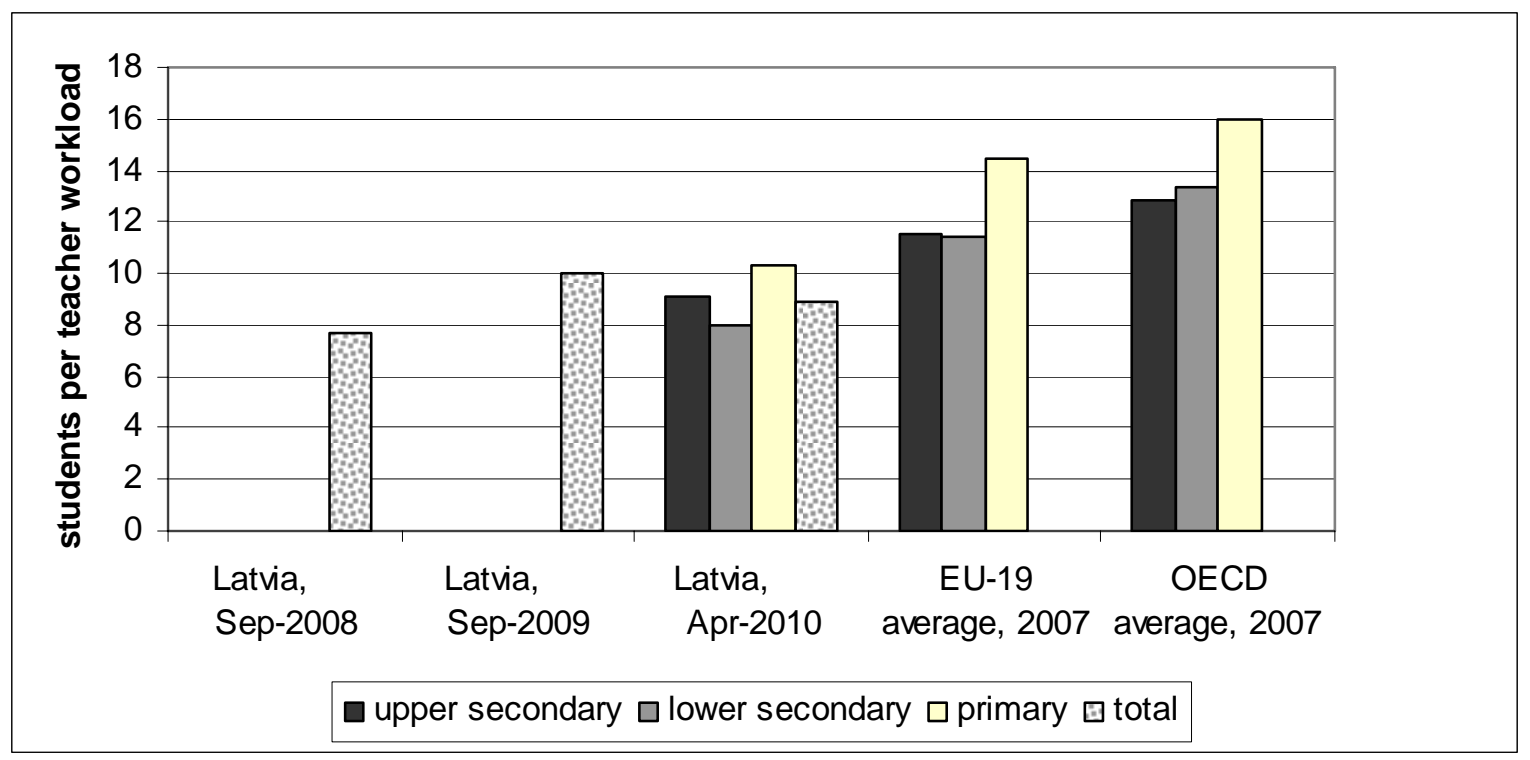

Figure 4 - Net student/teacher ratio in public schools of general education.

Latvia (2008-2010), EU-19, and OECD (2007).

Note: Calculation based on full-time equivalents. Teaching load of staff members, whose main task is not teaching, is excluded. For Latvia, boarding and special schools excluded. For primary education, EU-19 and OECD data refer to all (rather than just public) schools.

Source: Latvia - calculation with annual school census data and school level payroll data provided by MoES.

EU-19 and OECD - Education at a Glance, 2009, OECD, Paris, 2009, Tables D2.2 and D2.3

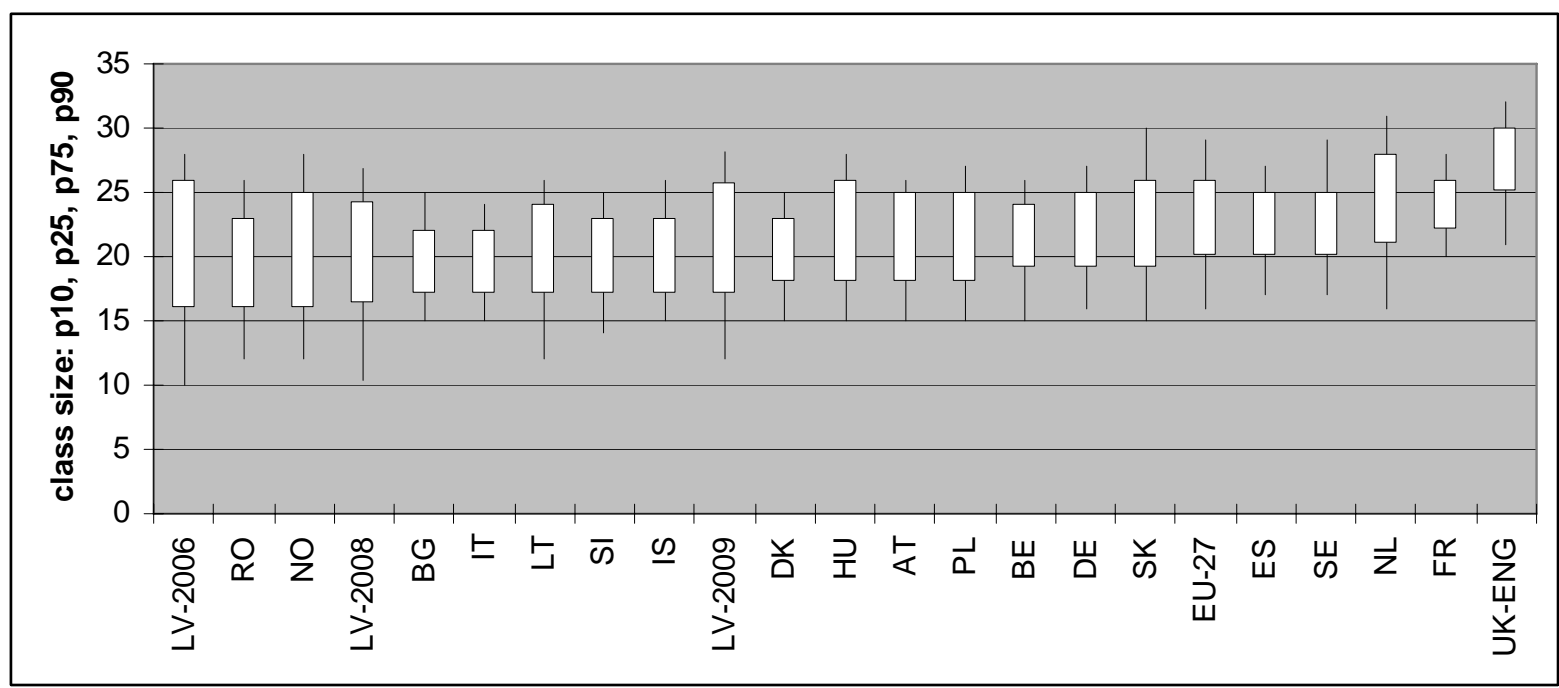

Figure 5 Percentiles (p10, p25, p75, and p90) of grade 4 students' distribution by class size. Selected European countries (2006) and Latvia (2006, 2008, 2009).

Countries sorted in ascending order of $p 25$.

Note: Interpretation: $p 25=17$ means that $25 \%$ of students in grade 4 are in classes of size $\leq 17$.

In other words, for a given country, $p 25$ (the lower base of the box) shows how small are 'small' classes there, and p10 (the lowest point of the lower segment) shows how small are 'very small' classes.

For Latvia 2008 \& 2009 data for grades 1-4 (rather than just grade 4) are presented. Boarding, special, and private schools excluded. Source: Elaboration on data from PIRLS 2006 database $^{39}$, as well as 2008 and 2009 data of Latvian school census provided by MoES.

${ }^{39}$ PIRLS - Progress in International Reading Literacy Study conducted every 5 years by the International Association for the Evaluation of Educational Achievement (IEA). Data are taken from p. 222 in Eurydice network publication „Key Data on Education in Europe 2009”: European Commisson, 2009. 


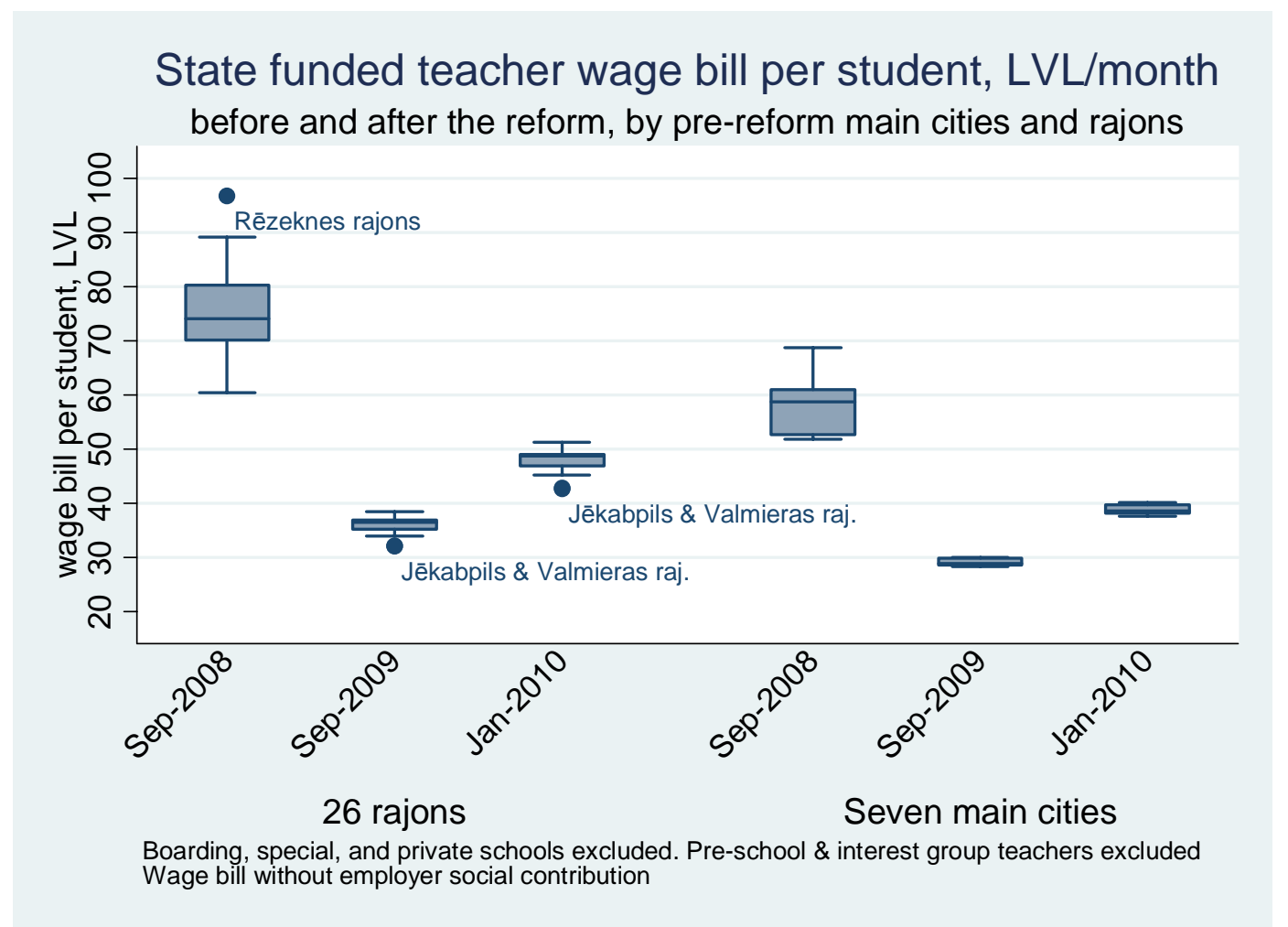

Figure 6 - The dispersion of state funded teacher wage bill per student among the seven main cities and among the 26 districts (rajons), September 2008, September 2009, and January 2010.

Notes: Boarding, special, and private schools excluded. Wage bill excludes compensation for pre-school and interest group teachers which is financed separately. Wage bill excludes employer social contribution. The boxplots present quartile distribution of each category; outliers are shown as separate points.

Source: Calculation with administrative data provided by MoES.

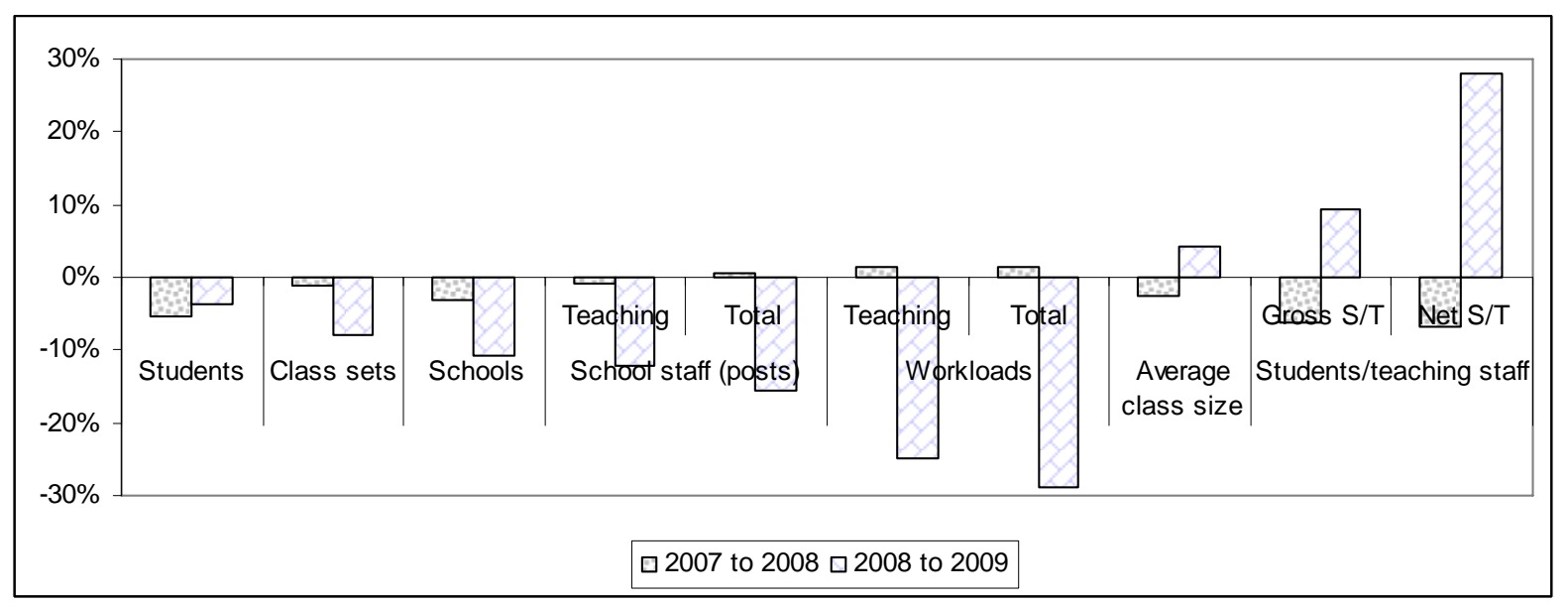

Figure 7 - Changes in Latvian general school system.

September 2007 - September 2009

Source Calculation with annual School Census data provided by MoES. 


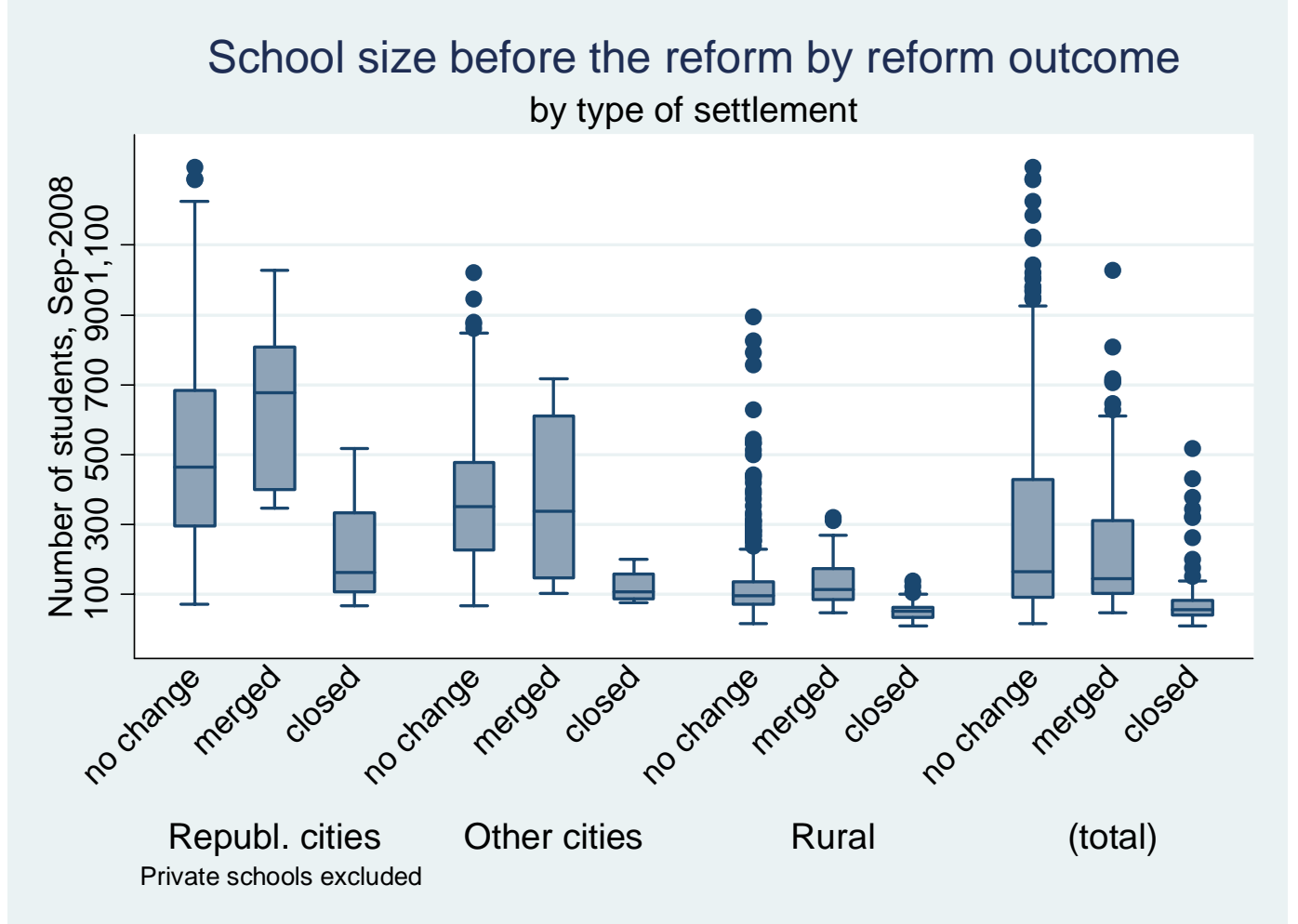

Figure 8 - Pre-reform size range of closed, reorganized and survived schools, by type of settlement

Note: The boxplots present quartile distribution of each category; outliers are shown as separate points.

Source: Calculation with administrative data provided by MoES.

Schools by change in workloads and staff, Sep-2009 vs. Sep-2008 by type of settlement

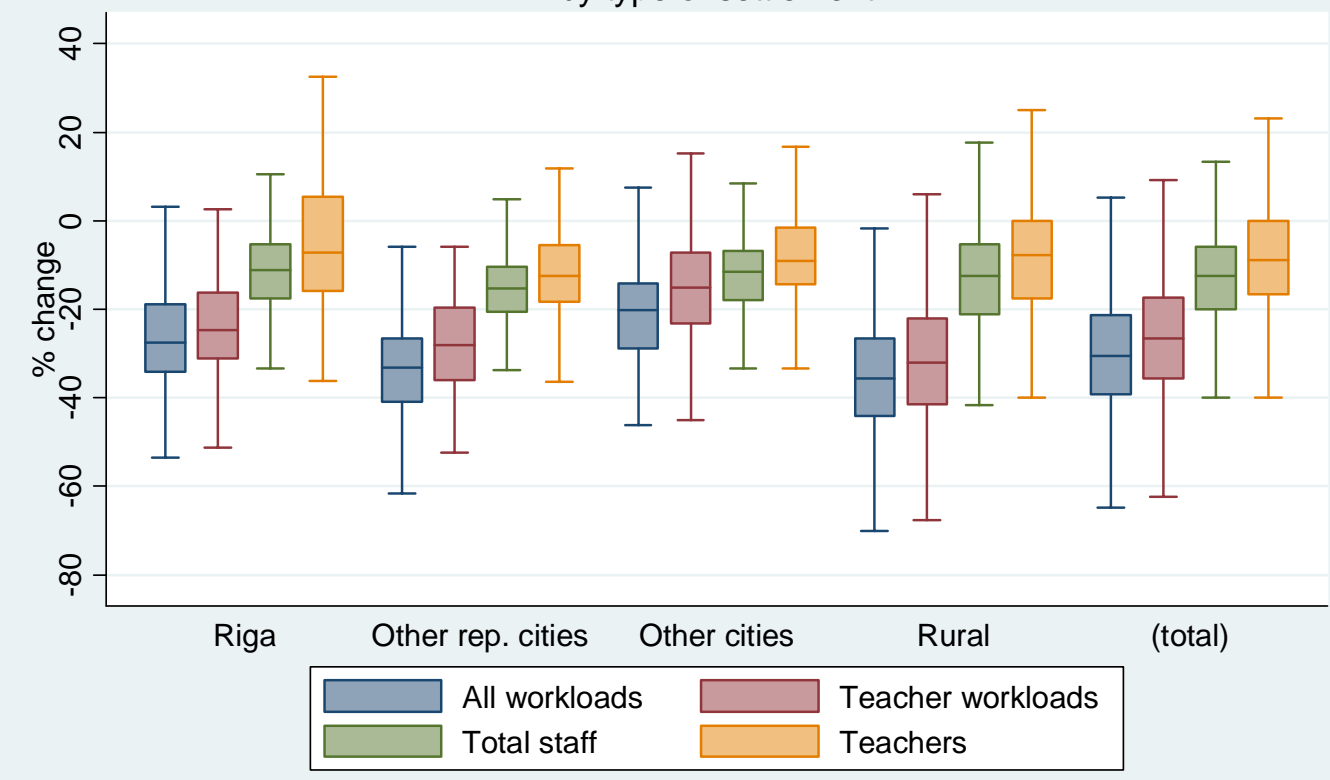

Boarding, special, and private schools, as well as schools reorganized during the reform, excluded Excludes outside values (schools with abnormally large positive or negative changes)

Figure 9 - Schools by \% change in workloads and staff, Sep-2009 vs. Sep-2008

Notes: Boarding, special, and private schools excluded. Schools reorganized (merged with other schools) during the reform, excluded. Schools with abnormally large positive or negative changes excluded. Source: Calculation with administrative data provided by MoES. 


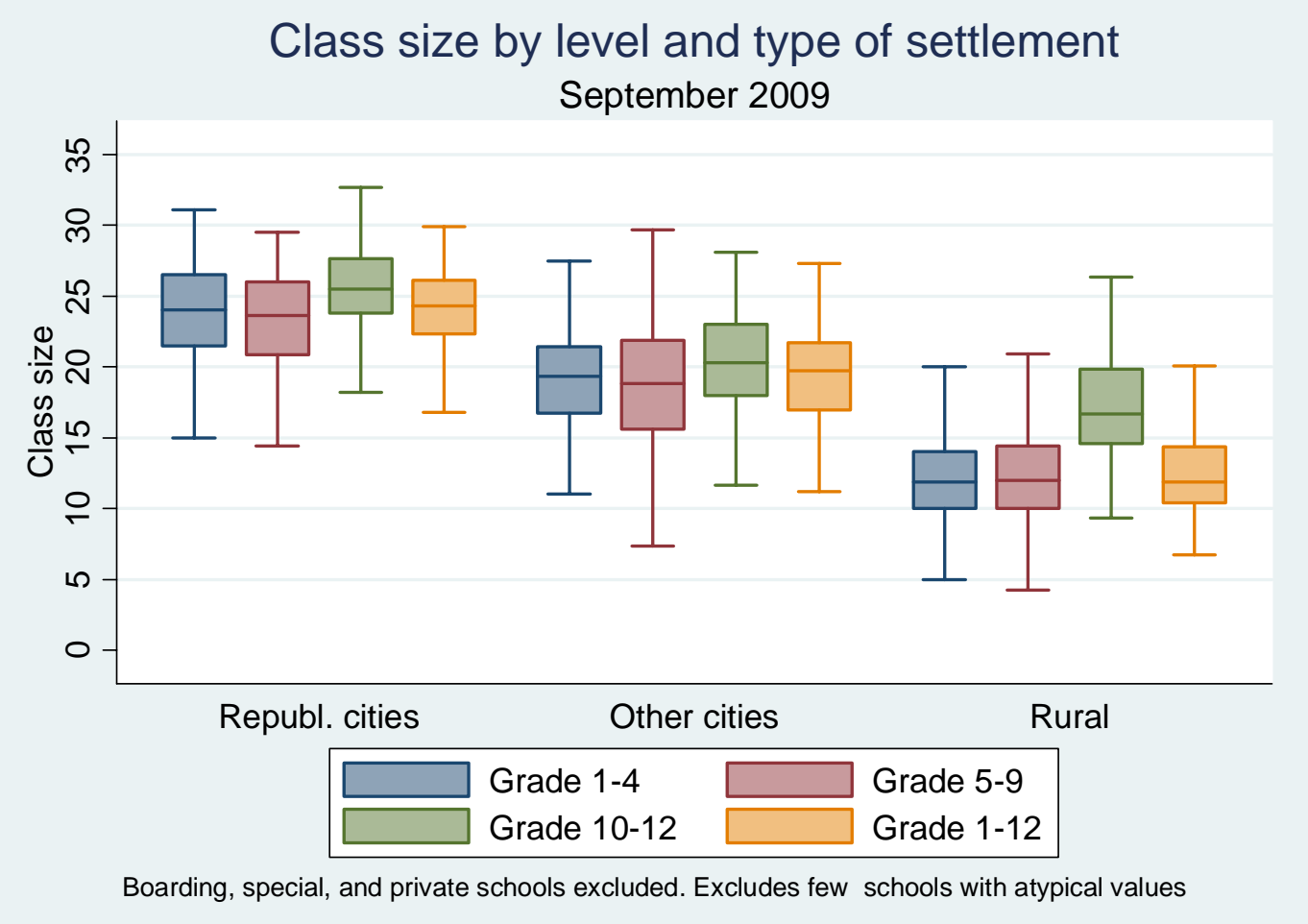

Figure 10 - Distribution of schools by class size in primary, lower secondary and upper secondary education, September 2009

(by type of settlement)

Note: Boarding, special, and private schools excluded.

Source: Calculation with annual school census data

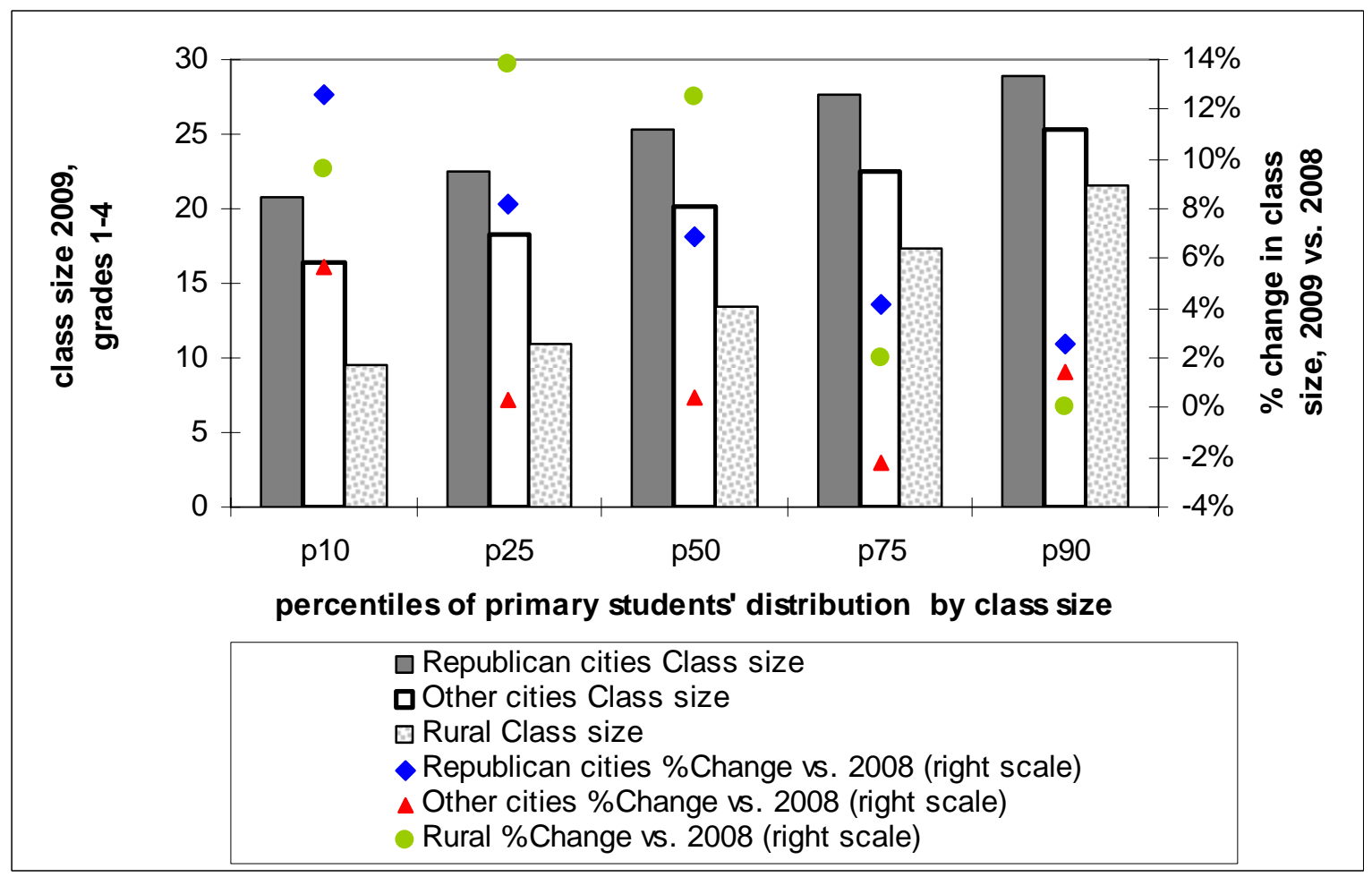

Figure 11- Percentiles (p10, p25, p75, and p90) of primary students' distribution by class size. Sep-2009 levels and changes vs. Sep-2008, by type of settlement.

Note: Boarding, special, and private schools excluded.

Source: Calculation with data of Latvian school census provided by MoES. 


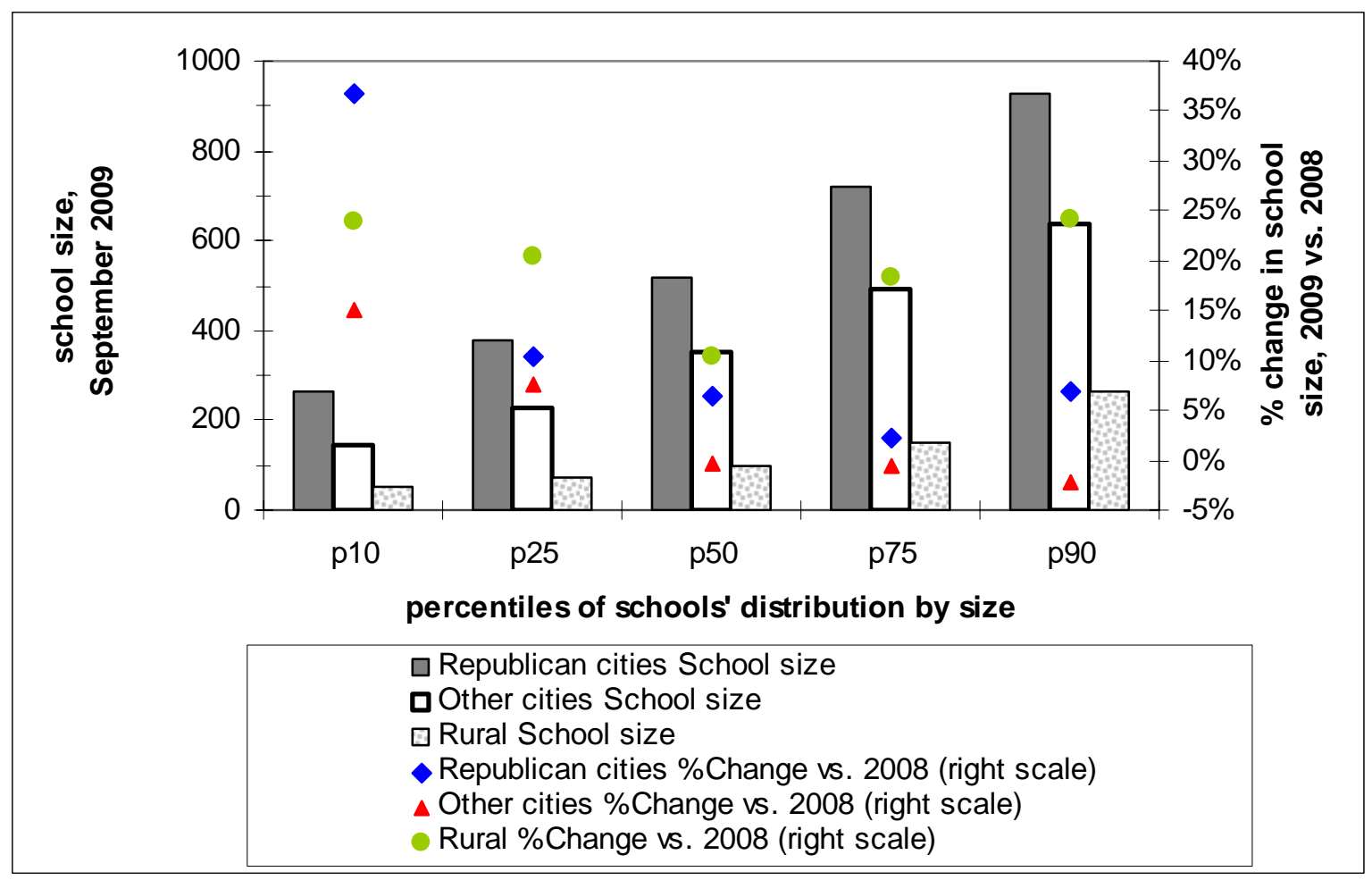

Figure 12 - Percentiles (p10, p25, p75, and p90) of schools' distribution by size.

September, 2009 and changes vs. September, 2008, by type of settlement.

Note: Boarding, special, and private schools excluded. Source: Calculation with administrative data.

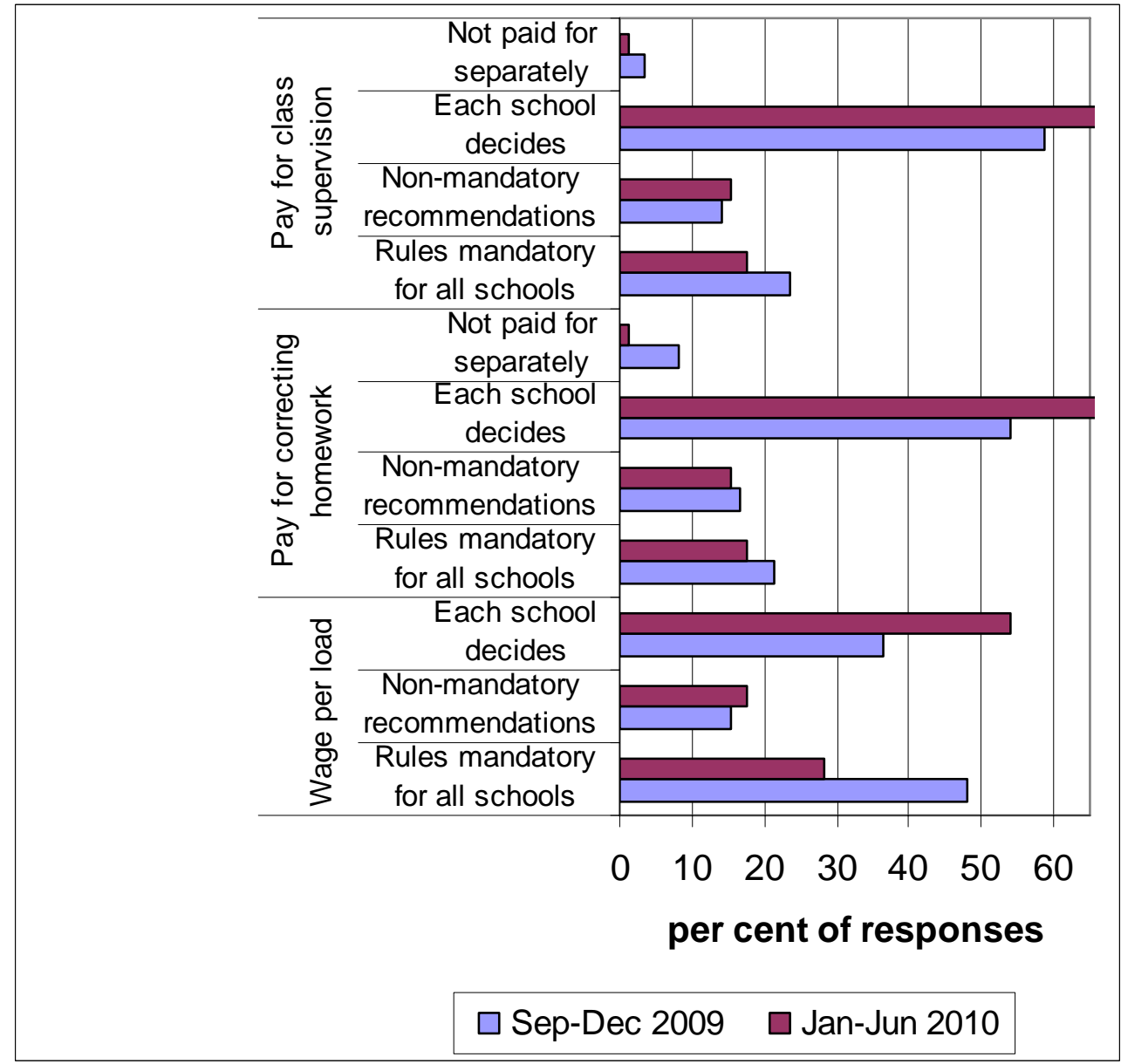

Figure 13 - Local regulations of wage per load, pay for homework correction, and pay for class supervision

Source: Calculation with data of the survey of local education authorities conducted in March 2010. 


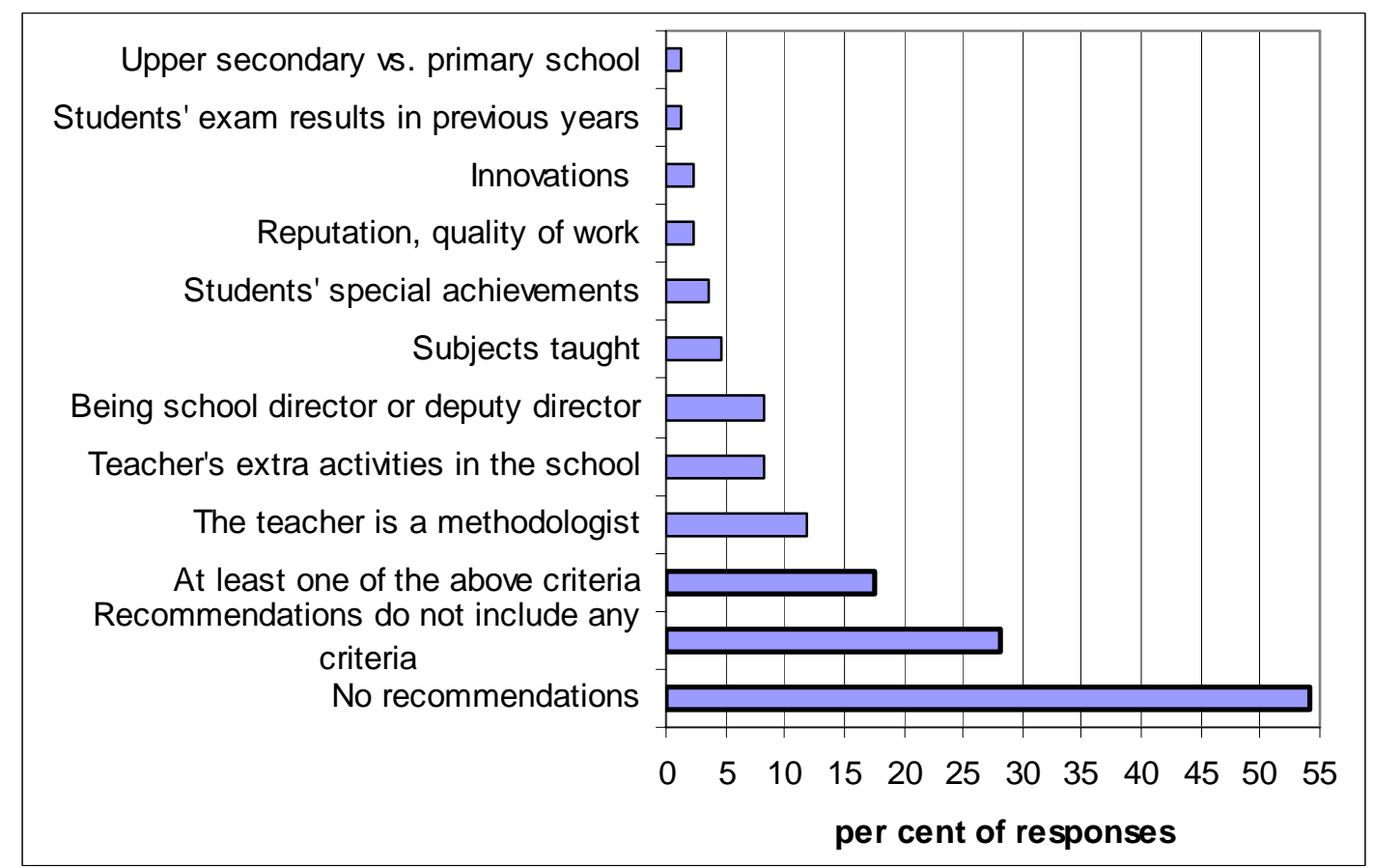

Figure 14 - Incidence of various criteria for differentiating wage per load in Spring semester of 2010 in recommendations by local authorities.

Notes: The base is the total number of responses (85), including those which indicated that no recommendations have been provided. Source: Calculation with data of the survey of local education authorities conducted in March 2010.

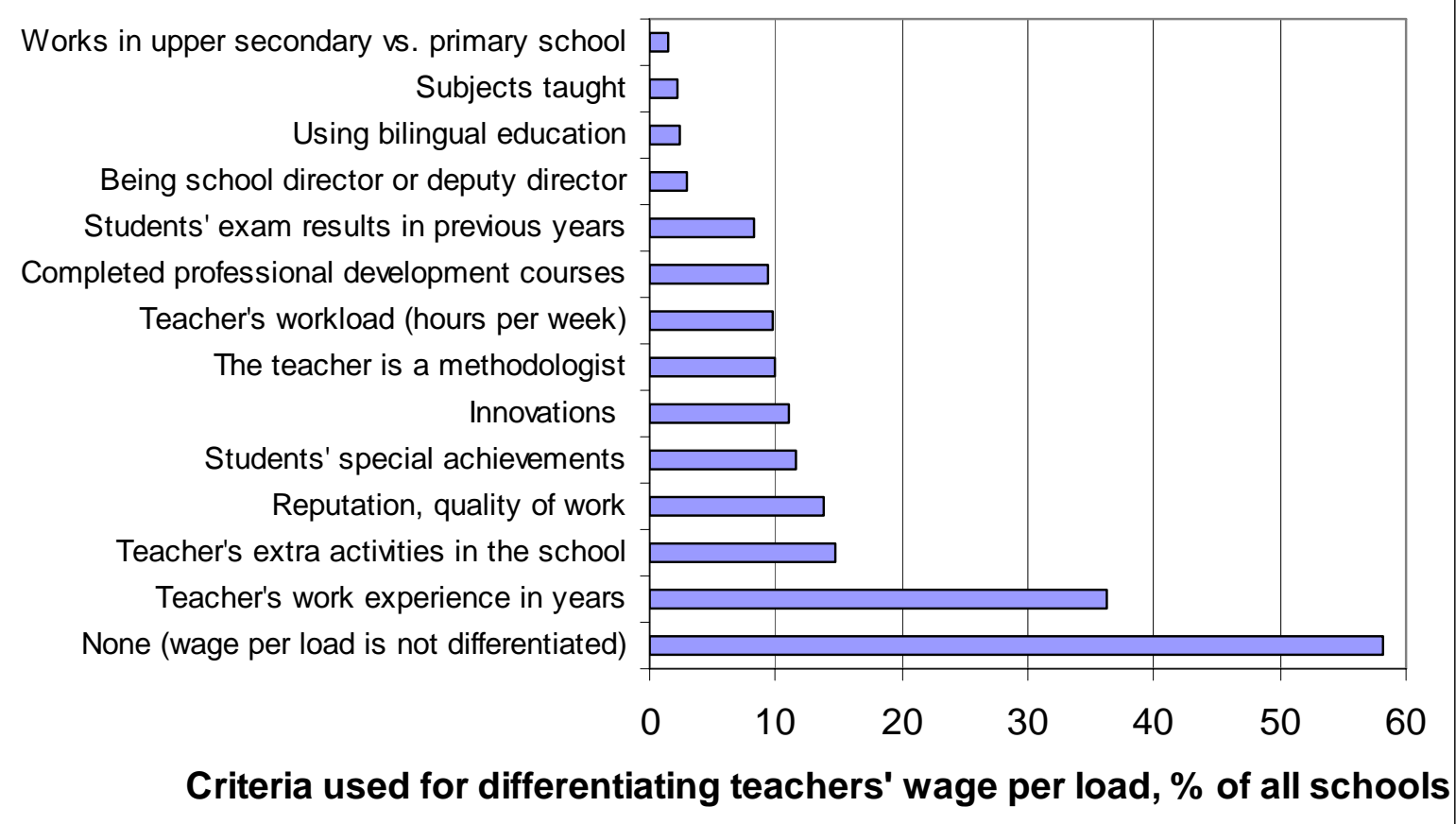

Figure 15 - Prevalence of various criteria applied by schools for teacher base salary differentiation. March 2010

Source: Calculation with data of the survey of school directors conducted in March 2010, N=577. 


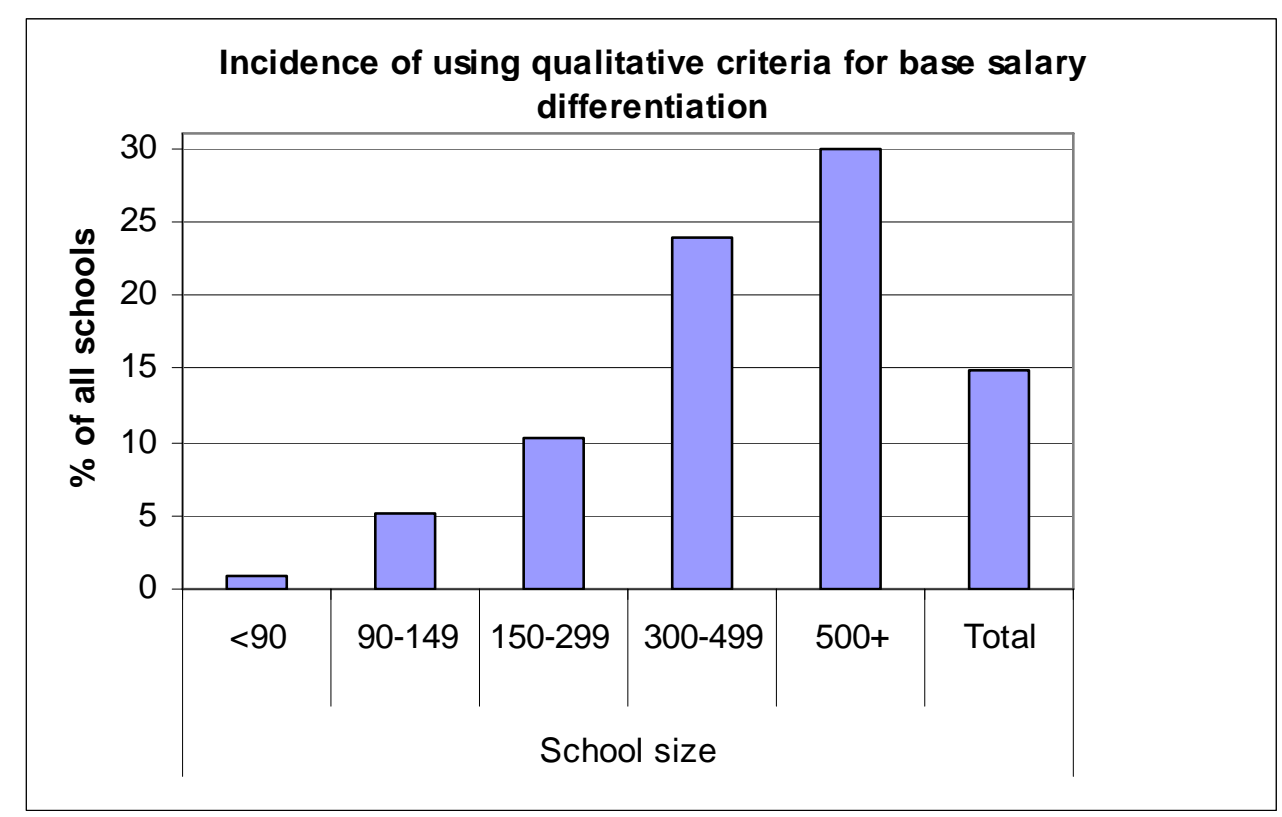

Figure 16 - Incidence of using qualitative criteria (teacher reputation, quality of work and innovation, students' exam results and special achievements)

for teacher base salary differentiation. March 2010, by school size

Source: Calculation with data of the survey of school directors conducted in March 2010, N=577.

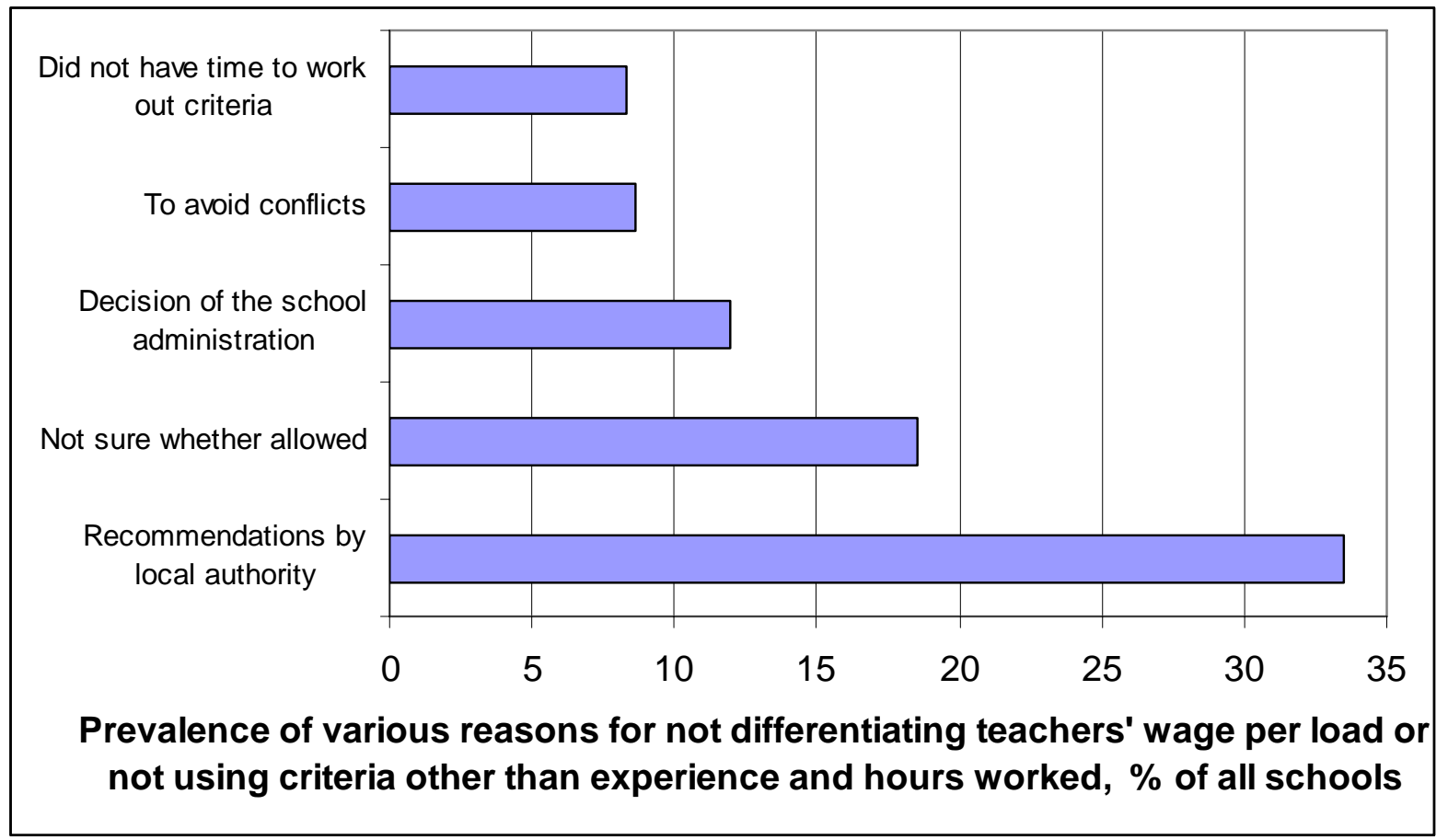

Figure 17 - Prevalence of reasons for not differentiating teacher base salary

Source: Calculation with data of the survey of school directors conducted in March 2010, N=577. 


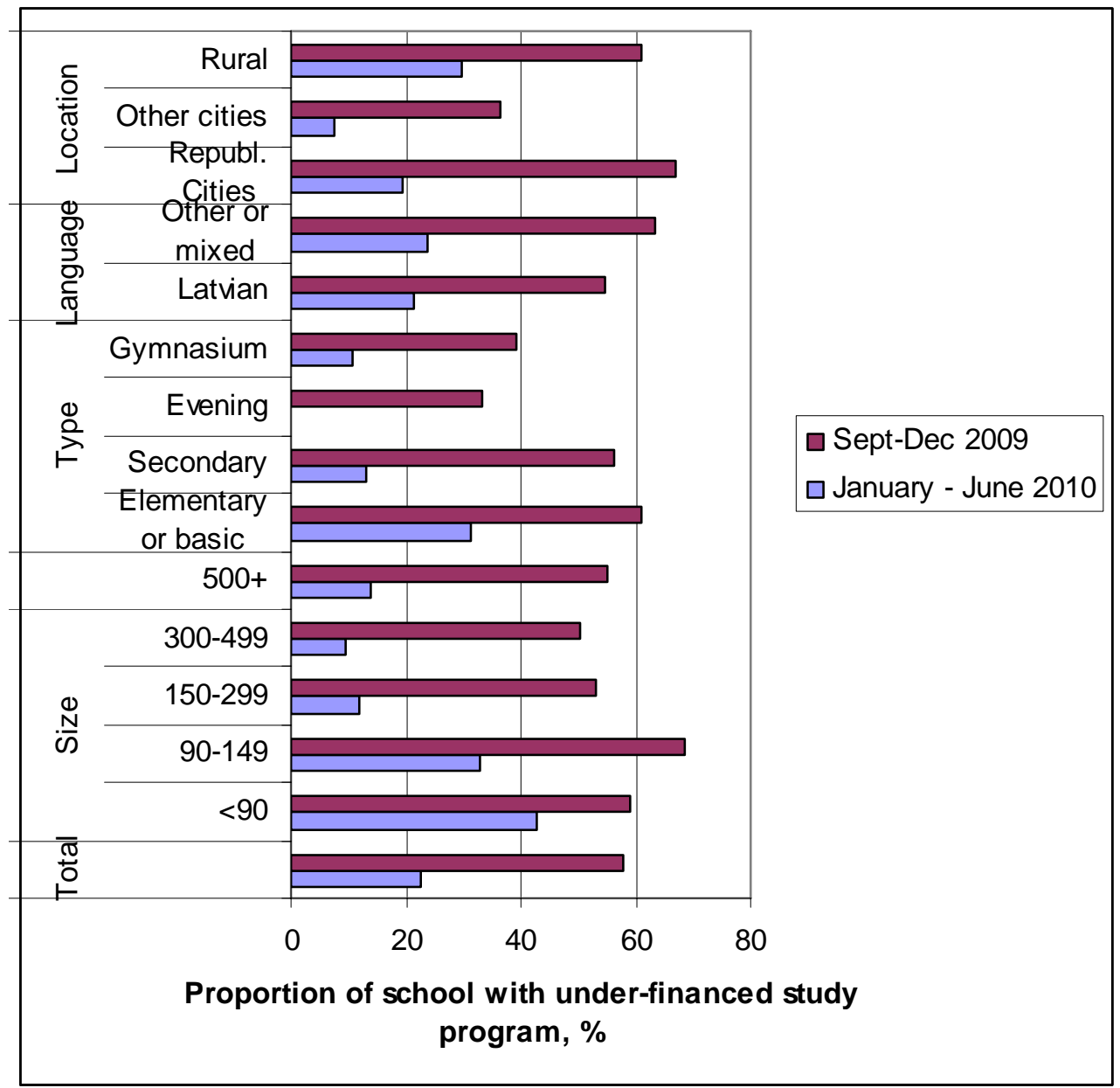

Figure 18 - Incidence of under-financed study programs,

Fall 2009 and Spring 2010

Source: Survey of school principals 


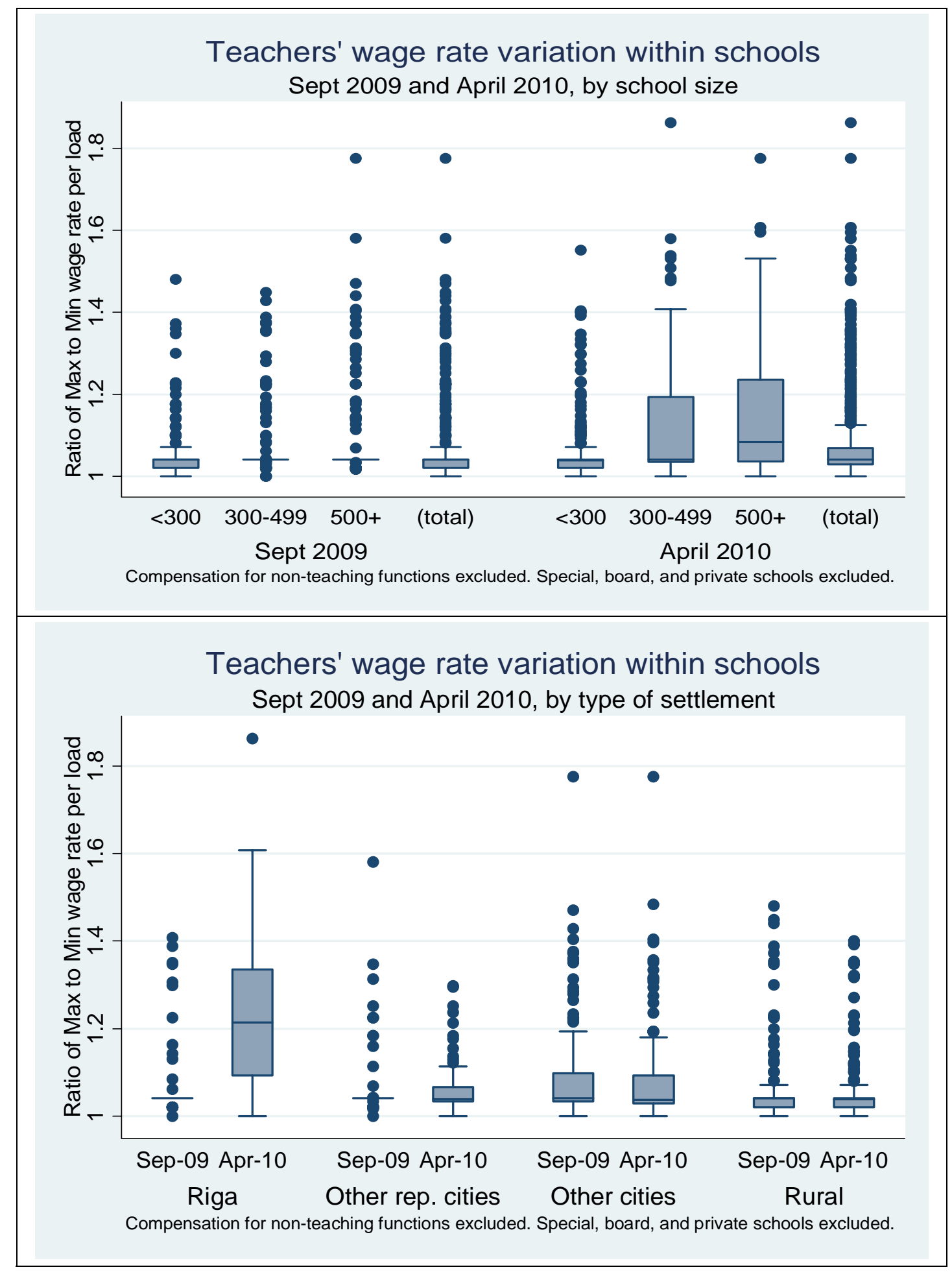

Figure 19 - Within-school ratio of highest to lowest wage rate per teaching load, Sept 2009 and April 2010. Top: by school size. Bottom: by type of settlement. Source: Calculation with payroll data provided by MoES 


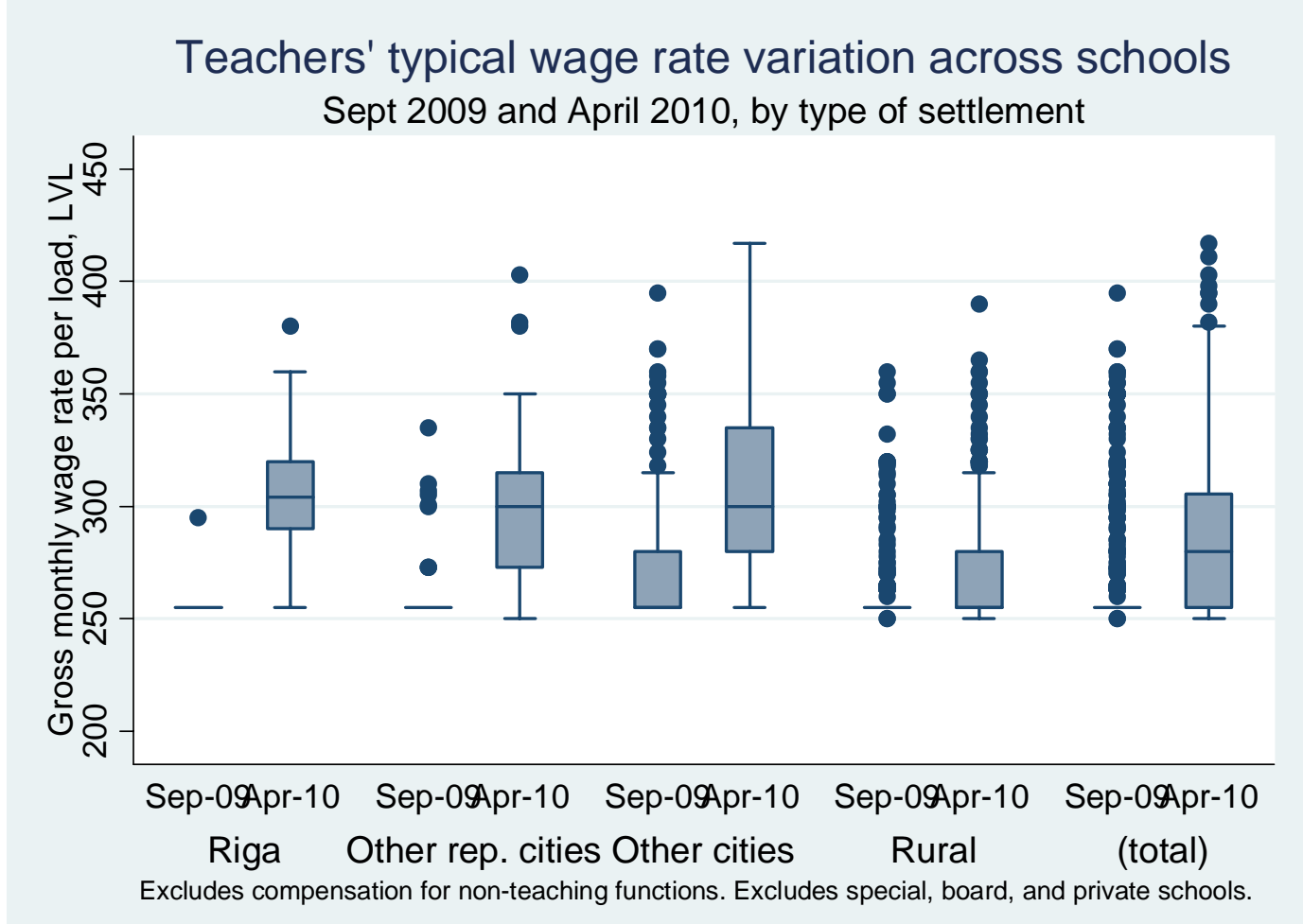

Figure 20 - Distribution of schools by typical (most frequent) wage rate per teaching load.

September 2009 and April 2010, by type of settlement

Source: Calculation with MOES school-level payroll data`

Variation of average teacher earnings across schools, April 2010

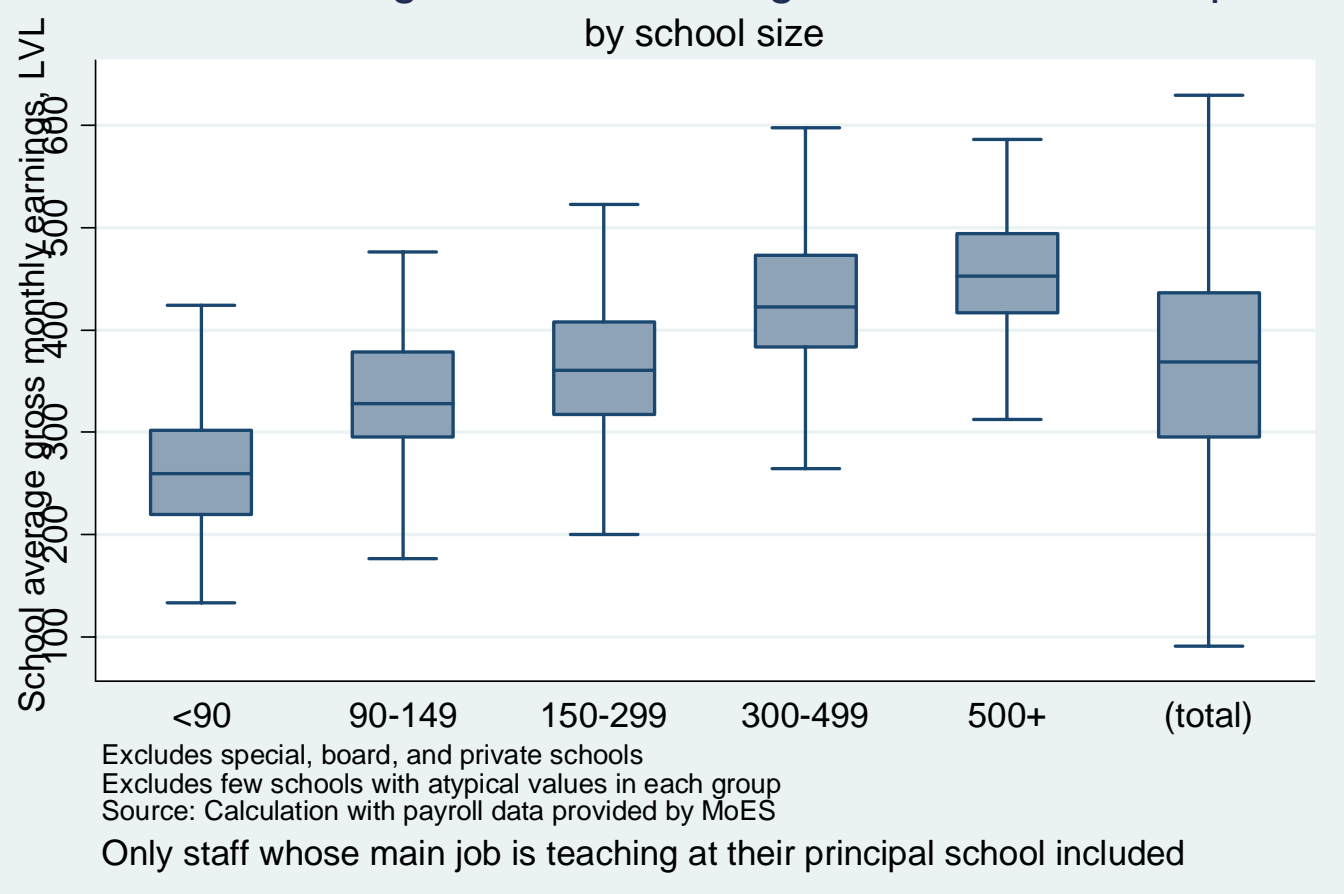

Figure 21 - Distribution of schools by average gross monthly earnings of classroom teachers at their principal school in April 2010, by school size

Notes: Compensation for all jobs in the given school included. Average earnings can fall below statutory salaries in schools with a large proportion of teachers carrying less than full workload.

Source: Calculation with payroll data provided by MoES 


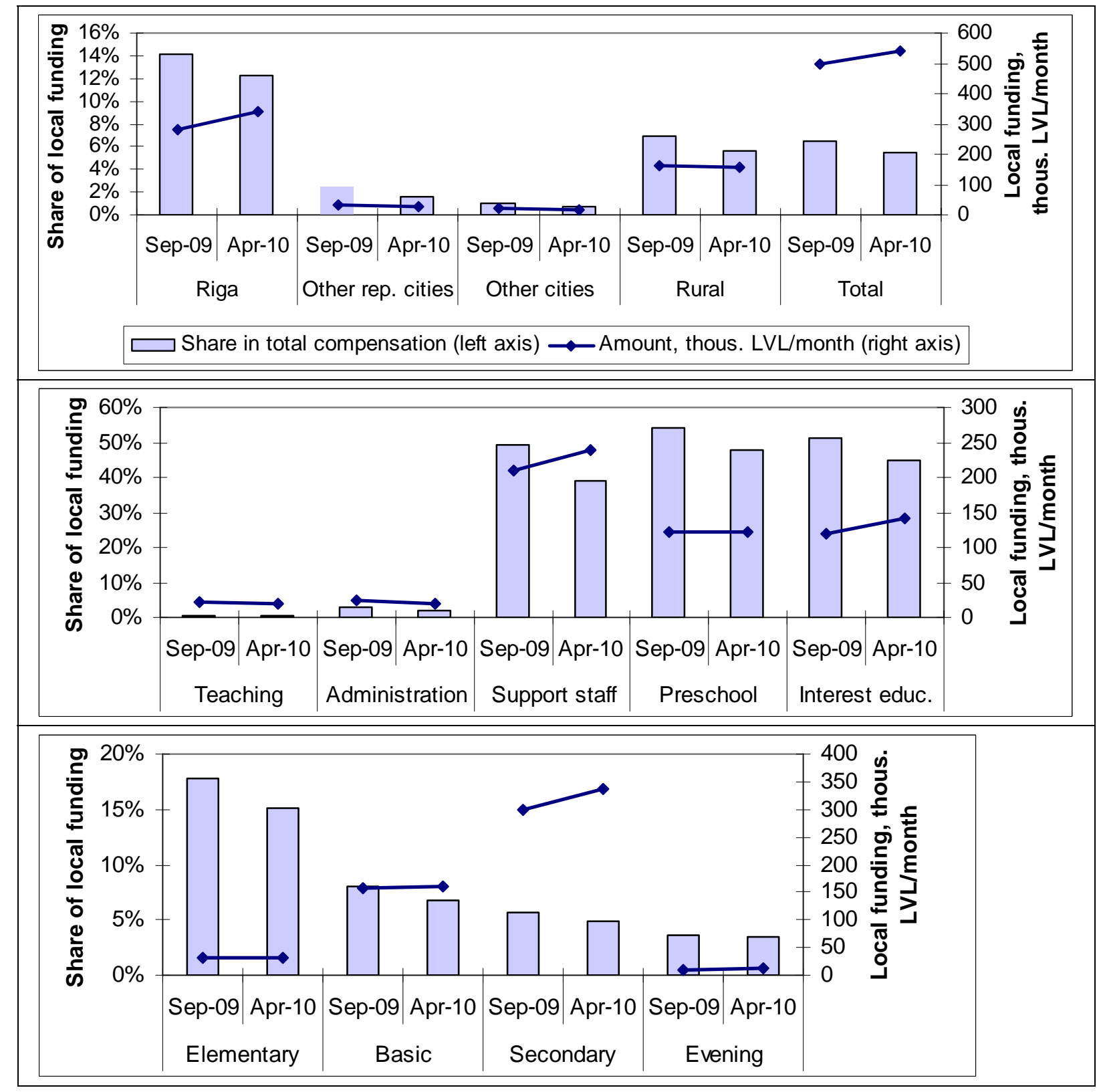

Figure 22 - Share and amount of municipal funding in teachers' total compensation. Top: by school location; Middle: by compensated functions; Bottom: by school type. September 2009 and April 2010

Notes: Board schools, special schools, and private schools excluded. Source: Calculation with payroll data provided by MoES. 
Municipalities by proportion of state subsidy transferred to schools by urbanization, April 2010

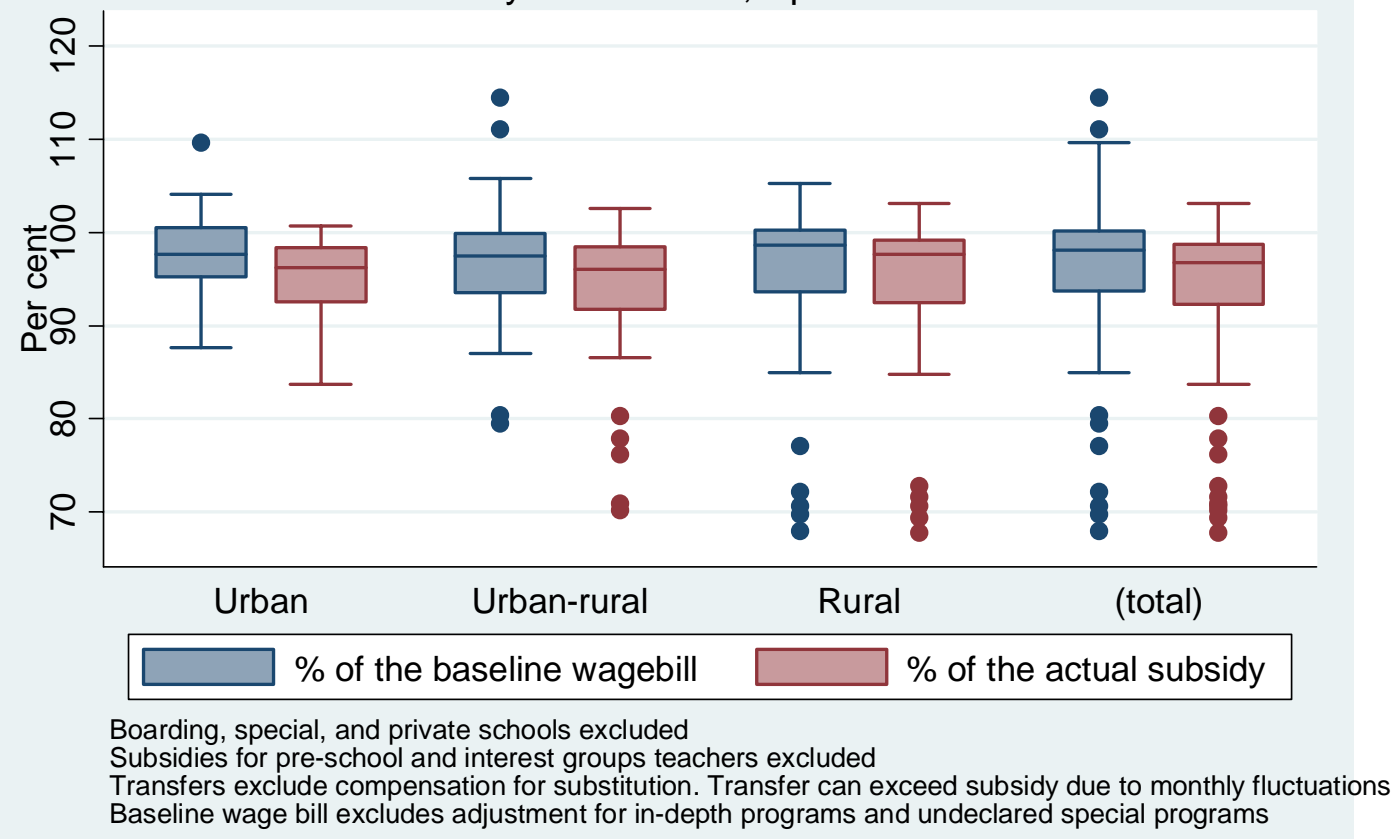

Figure 23 - Municipalities by proportion of the state subsidy transferred to schools, April 2010, by urbanization

Source: Calculation with school census, school payroll and budget planning data. 
Schools by received proportion of state-funded baseline wage bill Apri 2010, by school size

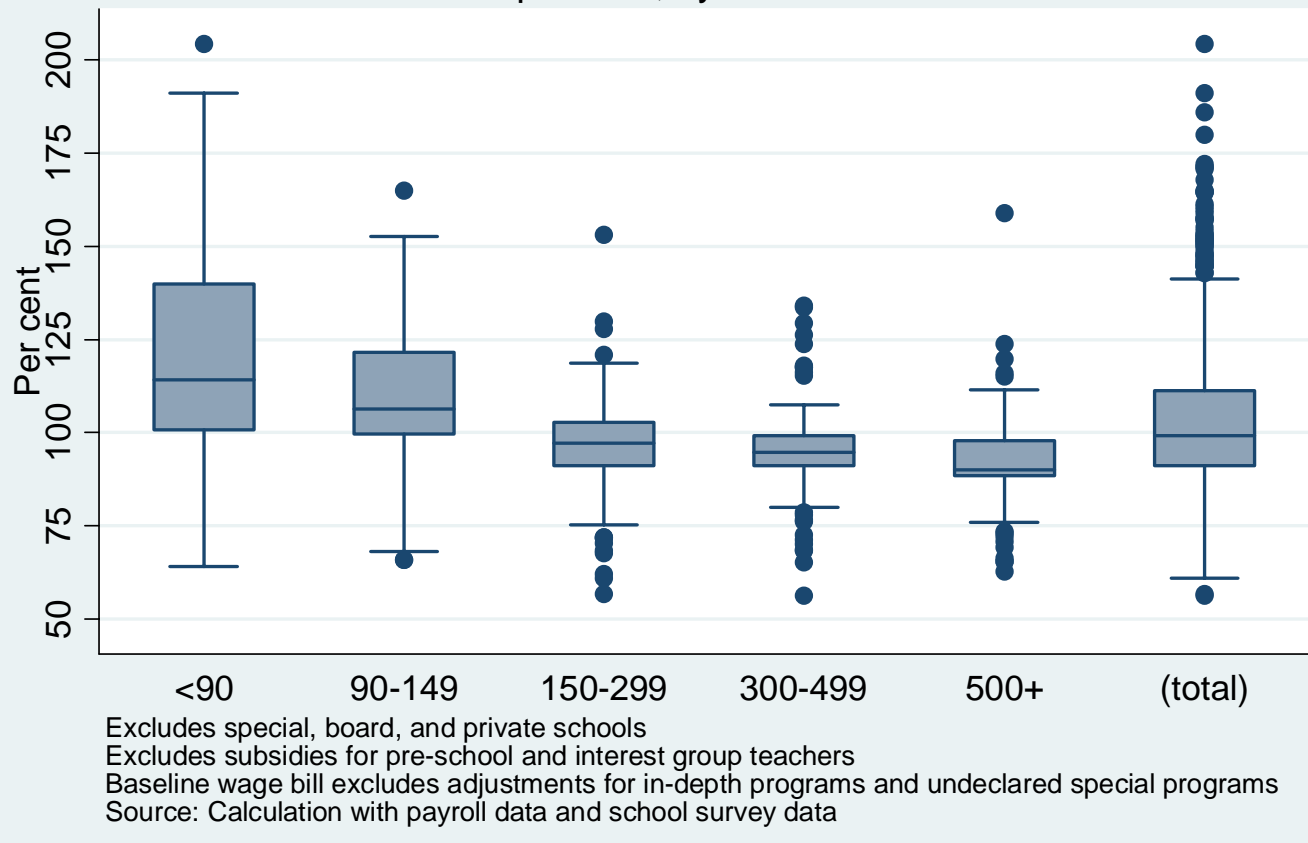

Schools by received proportion of state-funded baseline wage bill September 2009 \& April 2010, by school location

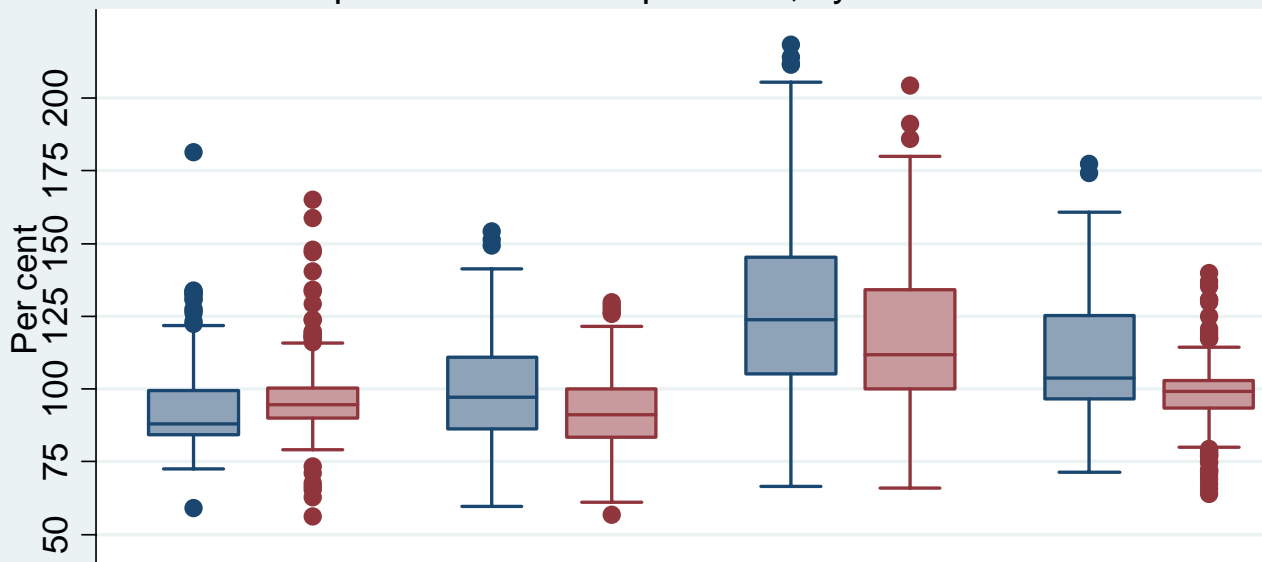

Urban municipality Town in mixed novadsRural in mixed novads Rural in rural novads

\begin{tabular}{|l|l|}
\hline Sep-2009 \\
\hline
\end{tabular}

Excludes special, board, and private schools

Excludes subsidies for pre-school and interest group teachers

Baseline wage bill excludes adjustments for in-depth programs and undeclared special programs

Source: Calculation with payroll data and school survey data

Figure 24 - Schools by received proportion of state-funded baseline wage bill Top chart: By school size. Bottom chart: By school location Source: Calculation with school payroll data and school census data 
Schools by received proportion of state-funded wage bill Apri 2010, by school type and claimed in-depth programs

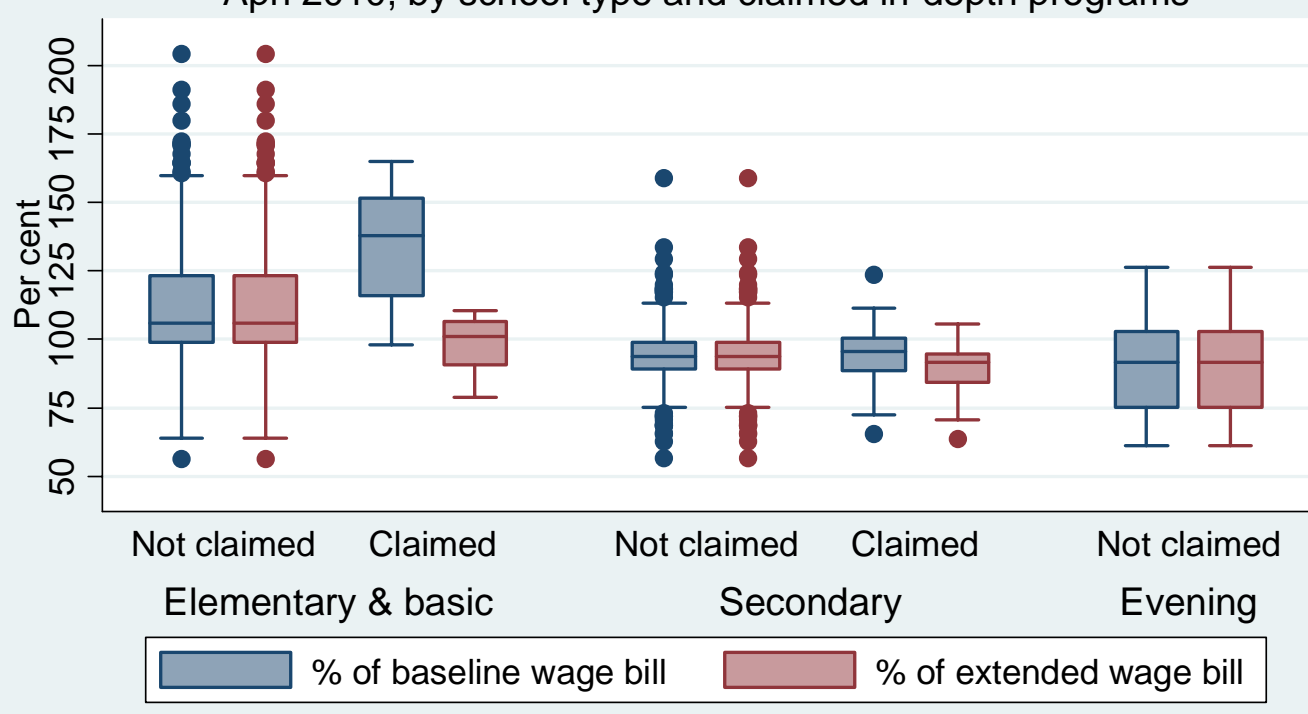

Excludes special, board, and private schools

Excludes subsidies for pre-school and interest group teachers

Baseline wage bill excludes adjustments for in-depth programs and undeclared special programs Source: Calculation with payroll data and school survey data

Figure 25 - Schools by received proportion of the state-funded wage bill, April 2010, by school type and claimed in-depth programs

Schools by received proportion of state-funded baseline wage bill, April 2010

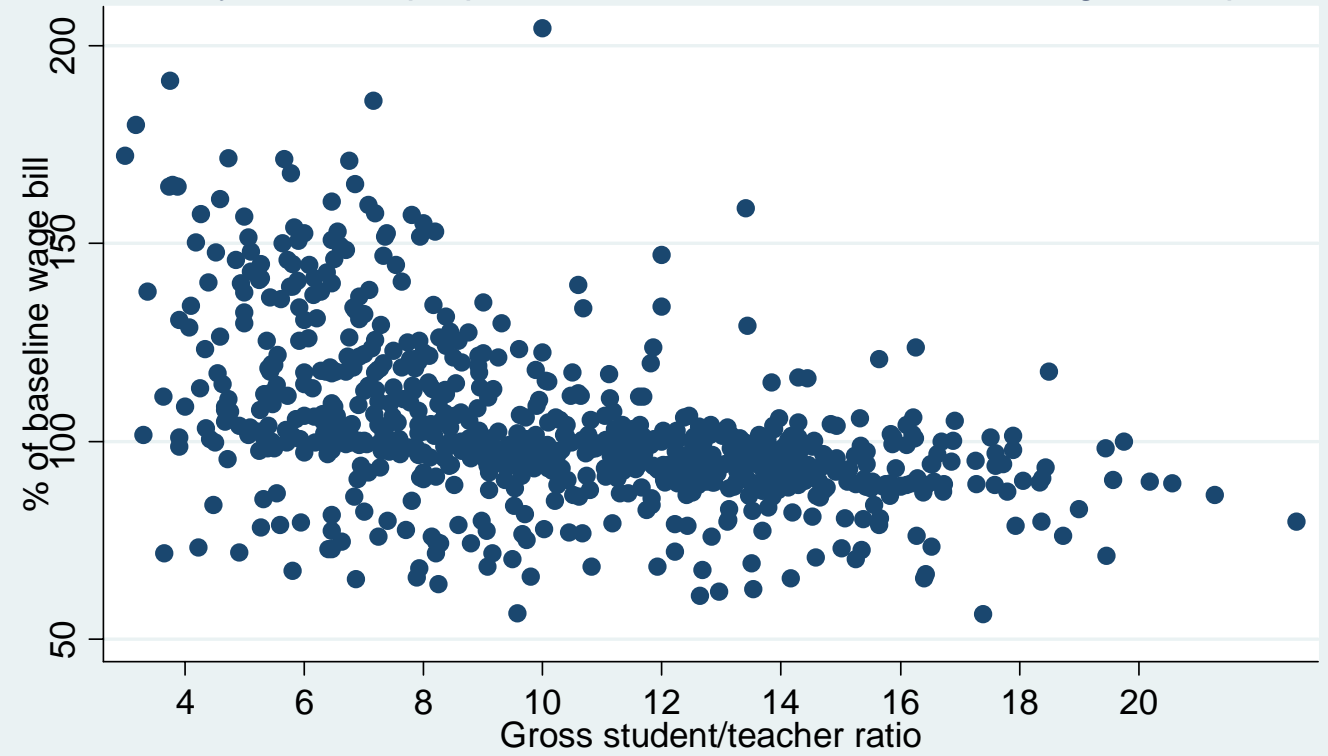

Excludes special, board, and private schools

Excludes subsidies for pre-school and interest group teachers

Baseline wage bill excludes adjustments for in-depth programs and undeclared special programs

Source: Calculation with payroll data and school survey data

Figure 26 - Schools by gross student/teacher ratio and received proportion of the state-funded baseline wage bill, April 2010

Source: Calculation with school payroll data and school census data 


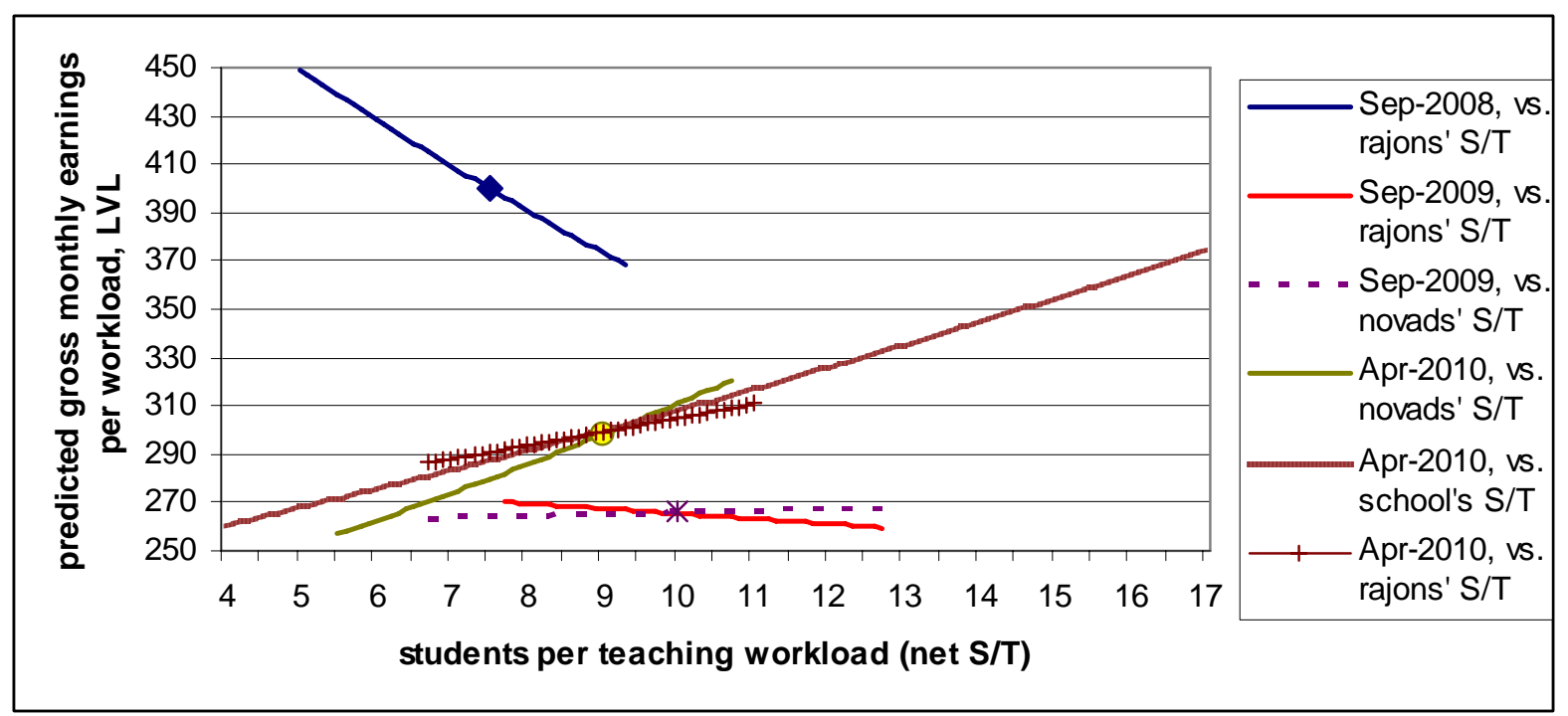

Figure 27 - Classroom teachers' predicted gross monthly earnings per teaching workload vs. net student/teacher ratio before and after the reform.

Notes: 'Rajons' (districts) are pre-reform municipalities. 'Novads' (counties) are post-reform municipalities (nested within rajons). Results refer to full-time teachers at the main job with completed higher education. School heads and deputy heads excluded. Special, board, and private schools excluded. Characteristics other than student/teacher ratio (teacher's gender and experience; language of instruction in the school; number of teachers in the school - see Table 10 for details) are fixed at their mean values for each of the three periods presented. Markers indicate an average teacher for each of the periods.

Sources: Calculations based on administrative data and results from Table 10 (col. [1b], model A; col. [2b], models A, C; col. [3b], models C, D).

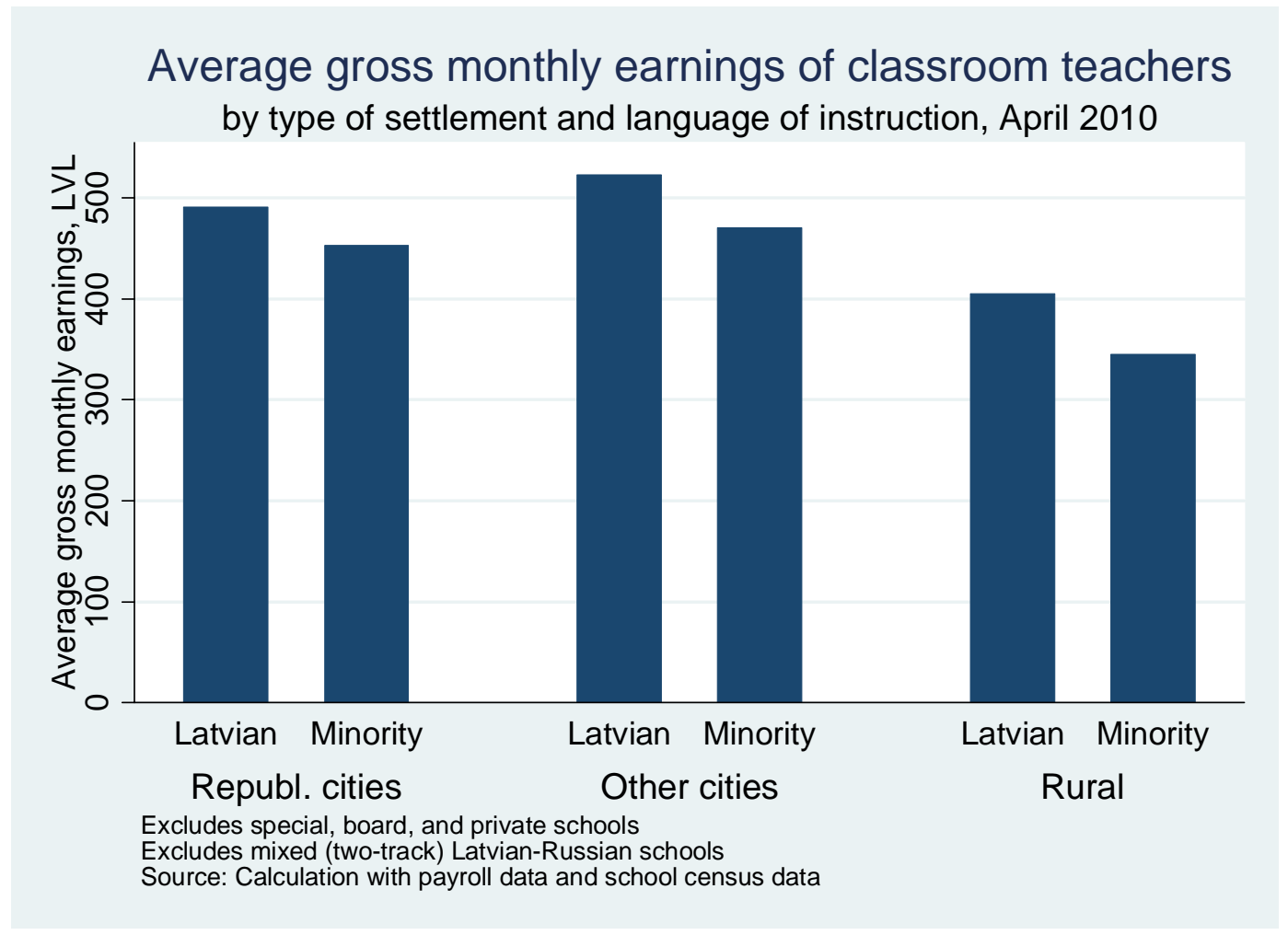

Figure 28 - Average gross monthly earnings of classroom teachers, by type of settlement and language of instruction, April 2010

Notes: Mixed Latvian-Russian schools excluded. $1 \mathrm{LVL}=1.42 \mathrm{EUR}$.

Source: Calculation with school payroll data and school census data. 